\title{
Interventions for ingrowing toenails (Review)
}

\author{
Eekhof JAH, Van Wijk B, Knuistingh Neven A, van der Wouden JC
}

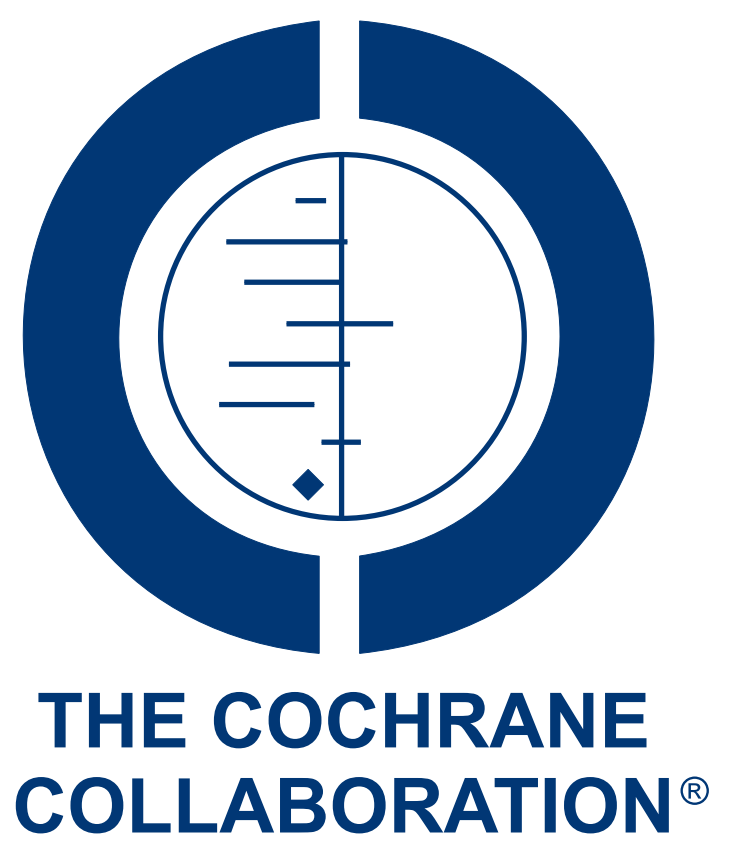

This is a reprint of a Cochrane review, prepared and maintained by The Cochrane Collaboration and published in The Cochrane Library 2012, Issue 4

http://www.thecochranelibrary.com

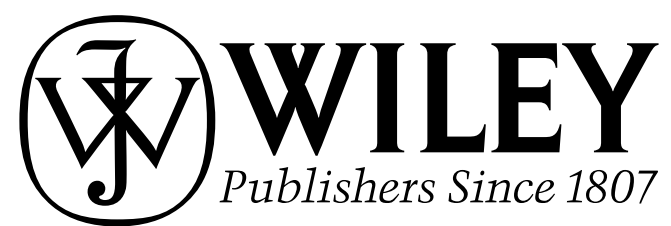

Interventions for ingrowing toenails (Review)

Copyright $\odot 2012$ The Cochrane Collaboration. Published by John Wiley \& Sons, Ltd. 
TABLE OF CONTENTS

HEADER . . . . . . . . . . . . . . . . . . . . . . . . . . . . . . . . 1

ABSTRACT .. . . . . . . . . . . . . . . . . . . . . . . . . . . . . . . . . . . . . . . . . . . . . . . . .

PLAIN LANGUAGE SUMMARY . . . . . . . . . . . . . . . . . . . . . . . . . . . . . . . . . . . $\quad$. 2

BACKGROUND . . . . . . . . . . . . . . . . . . . . . . . . . . . . . . . . . . . . 3

Figure 1. . . . . . . . . . . . . . . . . . . . . . . . . . . . . . . . . . . . . . 4

Figure 2. . . . . . . . . . . . . . . . . . . . . . . . . . . . . . . . . . . . . . 5

Figure 3. . . . . . . . . . . . . . . . . . . . . . . . . . . . . . . . . . . . . . 6

Figure $4 . \quad$. . . . . . . . . . . . . . . . . . . . . . . . . . . . . . . . . . . . . . 8

OBJECTIVES . . . . . . . . . . . . . . . . . . . . . . . . . . . . . . . . . . . . . . . . 9

METHODS . . . . . . . . . . . . . . . . . . . . . . . . . . . . . . . . . . . . . . 9

RESUlTS . . . . . . . . . . . . . . . . . . . . . . . . . . . . . . . . . . . . . . . 11

Figure 5. . . . . . . . . . . . . . . . . . . . . . . . . . . . . . . . . . . . . . 13

Figure 6. . . . . . . . . . . . . . . . . . . . . . . . . . . . . . . . . . . . . . 14

DISCUSSION . . . . . . . . . . . . . . . . . . . . . . . . . . . . . . . . . . . . 19

AUTHORS' CONCLUSIONS . . . . . . . . . . . . . . . . . . . . . . . . . . . . . . . . . . . . . . .

ACKNOWLEDGEMENTS . . . . . . . . . . . . . . . . . . . . . . . . . . . . . . . . . . . . . . . . . . $\quad 21$

REFERENCES . . . . . . . . . . . . . . . . . . . . . . . . . . . . . . . . . . . . . 21

CHARACTERISTICS OF STUDIES . . . . . . . . . . . . . . . . . . . . . . . . . . . . . . . . 24

DATA AND ANALYSES . . . . . . . . . . . . . . . . . . . . . . . . . . . . . . . . . . . . . . . . . . . . . $\quad 54$

Analysis 1.1. Comparison 1 Non-surgical procedures, Outcome 1 Recurrence. . . . . . . . . . . . . . . . . 59

Analysis 2.1. Comparison 2 Non-surgical vs surgical procedures, Outcome 1 Recurrence. . . . . . . . . . . . . 60

Analysis 3.1. Comparison 3 Surgical procedures: Chem abln \& surg vs surg proc, Outcome 1 Recurrence. . . . . 61

Analysis 3.2. Comparison 3 Surgical procedures: Chem abln \& surg vs surg proc, Outcome 2 Pain of operation. $\quad$. $\quad 62$

Analysis 3.3. Comparison 3 Surgical procedures: Chem abln \& surg vs surg proc, Outcome 3 Postoperative infection. 62

Analysis 3.4. Comparison 3 Surgical procedures: Chem abln \& surg vs surg proc, Outcome 4 Postoperative haemorrhage. 64

Analysis 3.5. Comparison 3 Surgical procedures: Chem abln \& surg vs surg proc, Outcome 5 Postoperative analgesic use. 64

Analysis 3.6. Comparison 3 Surgical procedures: Chem abln \& surg vs surg proc, Outcome 6 Postoperative pain at 2 weeks (VAS).

Analysis 3.7. Comparison 3 Surgical procedures: Chem abln \& surg vs surg proc, Outcome 7 Participant satisfaction. 65

Analysis 4.1. Comparison 4 Surgical procedures: Different types of surg proc, Outcome 1 Recurrence. . . . . . 66

Analysis 4.2. Comparison 4 Surgical procedures: Different types of surg proc, Outcome 2 Participant satisfaction. $\quad$. 66

Analysis 4.3. Comparison 4 Surgical procedures: Different types of surg proc, Outcome 3 Postoperative infection. $\quad$. 67

Analysis 5.1. Comparison 5 Surgical procedures: Chem abln \& partial avul vs chem abln \& surg, Outcome 1 Recurrence. 67

Analysis 5.2. Comparison 5 Surgical procedures: Chem abln $\&$ partial avul vs chem abln \& surg, Outcome 2 Postoperative pain (yes/no). . . . . . . . . . . . . . . . . . . . . . . . . . . . . . . . . . . . . . . . 68

Analysis 5.3. Comparison 5 Surgical procedures: Chem abln \& partial avul vs chem abln \& surg, Outcome 3 Postoperative pain intensity after $24 \mathrm{~h}$ duration. . . . . . . . . . . . . . . . . . . . . . . . . . . . . . 68

Analysis 6.1. Comparison 6 Surgical procedures: Wedge + electroful vs wedge + surg ME, Outcome 1 Postoperative pain at 2 weeks.

Analysis 6.2. Comparison 6 Surgical procedures: Wedge + electroful vs wedge + surg ME, Outcome 2 Postoperative haemorrhage at 2 weeks. . . . . . . . . . . . . . . . . . . . . . . . . . . . . . . . . . . . . . 69

Analysis 7.1. Comparison 7 Postoperative procedures, Outcome 1 Recurrence. . . . . . . . . . . . . . . 70

Analysis 7.2. Comparison 7 Postoperative procedures, Outcome 2 Postoperative infection. . . . . . . . . . . . . 70

Analysis 7.3. Comparison 7 Postoperative procedures, Outcome 3 Postoperative pain (VAS). . . . . . . . . . . . 71

Analysis 7.4. Comparison 7 Postoperative procedures, Outcome 4 Healing time (days). . . . . . . . . . . . . . . 72

Analysis 8.1. Comparison 8 Surgery plus postoperative treatment vs surgery, Outcome 1 Recurrence. . . . . . . 72

Analysis 8.2. Comparison 8 Surgery plus postoperative treatment vs surgery, Outcome 2 Postoperative infection. . . $\quad 73$

Analysis 9.1. Comparison 9 Surgery plus postoperative treatment vs phenol, Outcome 1 Recurrence. . . . . . . 73

Analysis 9.2. Comparison 9 Surgery plus postoperative treatment vs phenol, Outcome 2 Postoperative infection. . . $\quad 74$

Analysis 10.1. Comparison 10 Phenol plus postoperative treatment vs phenol, Outcome 1 Recurrence. . . . . . 74

Analysis 10.2. Comparison 10 Phenol plus postoperative treatment vs phenol, Outcome 2 Postoperative infection. $\quad . \quad 75$ 
Analysis 10.3. Comparison 10 Phenol plus postoperative treatment vs phenol, Outcome 3 Healing time (weeks). . . 75

Analysis 11.1. Comparison 11 Phenol plus postoperative treatment vs surgery, Outcome 1 Recurrence. . . . . . 76

Analysis 11.2. Comparison 11 Phenol plus postoperative treatment vs surgery, Outcome 2 Postoperative infection. $\quad$. 76

Analysis 12.1. Comparison 12 Preoperative treatment vs postoperative treatment, Outcome 1 Healing time (weeks). 77

Analysis 13.1. Comparison 13 Preoperative treatment vs surgery, Outcome 1 Postoperative infection. . . . . . . 77

Analysis 13.2. Comparison 13 Preoperative treatment vs surgery, Outcome 2 Healing time (weeks). . . . . . . . 78

APPENDICES . . . . . . . . . . . . . . . . . . . . . . . . . . . . . . . . . . . . . 78

WHAT'S NEW . . . . . . . . . . . . . . . . . . . . . . . . . . . . . . . . . . . . . . . . . . . . . 79

HISTORY . . . . . . . . . . . . . . . . . . . . . . . . . . . . . . . . . . . . . . . 79

CONTRIBUTIONS OF AUTHORS . . . . . . . . . . . . . . . . . . . . . . . . . . . . . . . . . . . . . . . . $\quad . \quad 80$

DECLARATIONS OF INTEREST . . . . . . . . . . . . . . . . . . . . . . . . . . . . . . . . . . . . . . . . $\quad . \quad 80$

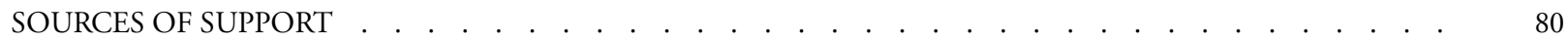

DIFFERENCES BETWEEN PROTOCOL AND REVIEW . . . . . . . . . . . . . . . . . . . . . . . . 80

INDEX TERMS . . . . . . . . . . . . . . . . . . . . . . . . . . . . . . . . . . . . . . . . 81 


\title{
[Intervention Review]
}

\section{Interventions for ingrowing toenails}

\author{
Just AH Eekhof ${ }^{1}$, Bart Van Wijk ${ }^{1}$, Arie Knuistingh Neven ${ }^{1}$, Johannes C van der Wouden ${ }^{2,3}$ \\ ${ }^{1}$ Department of Public Health and Primary Care, Leiden University Medical Center, Leiden, Netherlands. ${ }^{2}$ Department of General \\ Practice and EMGO Institute for Health and Care Research, VU University Medical Center, Amsterdam, Netherlands. ${ }^{3}$ Department \\ of General Practice, Erasmus Medical Center, Rotterdam, Netherlands
}

Contact address: Just AH Eekhof, Department of Public Health and Primary Care, Leiden University Medical Center, PO Box 9600 , Leiden, 2300 RC, Netherlands. J.A.H.Eekhof@LUMC.nl.

Editorial group: Cochrane Skin Group.

Publication status and date: New search for studies and content updated (conclusions changed), published in Issue 4, 2012.

Review content assessed as up-to-date: 20 January 2010.

Citation: Eekhof JAH, Van Wijk B, Knuistingh Neven A, van der Wouden JC. Interventions for ingrowing toenails. Cochrane Database of Systematic Reviews 2012, Issue 4. Art. No.: CD001541. DOI: 10.1002/14651858.CD001541.pub3.

Copyright @ 2012 The Cochrane Collaboration. Published by John Wiley \& Sons, Ltd.

\section{A B S T R A C T}

\section{Background}

Ingrowing toenails are a common problem in which part of the nail penetrates the skinfold alongside the nail, creating a painful area. Different non-surgical and surgical interventions for ingrowing toenails are available, but there is no consensus about a standard firstchoice treatment.

\section{Objectives}

To evaluate the effects of non-surgical and surgical interventions in a medical setting for ingrowing toenails, with the aim of relieving symptoms and preventing regrowth of the nail edge or recurrence of the ingrowing toenail.

\section{Search methods}

We updated our searches of the following databases to January 2010: the Cochrane Skin Group Specialised Register, CENTRAL in The Cochrane Library, MEDLINE, and EMBASE. We also updated our searches of CINAHL, WEB of SCIENCE, ongoing trials databases, and reference lists of articles.

\section{Selection criteria}

Randomised controlled trials of non-surgical and surgical interventions for ingrowing toenails, which are also known by the terms 'unguis incarnatus' and 'onychocryptosis', and those comparing postoperative treatment options. Studies must have had a follow-up period of at least one month.

\section{Data collection and analysis}

Two authors independently selected studies, assessed methodological quality, and extracted data from selected studies. We analysed outcomes as risk ratios (RR) with $95 \%$ confidence intervals (CI).

\section{Main results}

This is an update of the Cochrane review 'Surgical treatments for ingrowing toenails'. In this update we included 24 studies, with a total of 2826 participants (of which 7 were also included in the previous review). Five studies were on non-surgical interventions, and 19 were on surgical interventions. 
The risk of bias of each included study was assessed; this is a measure of the methodological quality of several characteristics in these studies. It was found to be unclear for several items, due to incomplete reporting. Participants were not blinded to the treatment they received because of the nature of the interventions, e.g. surgery or wearing a brace on the toe. Outcome assessors were reported to be blinded in only 9 of the 24 studies.

None of the included studies addressed our primary outcomes of 'relief of symptoms' or 'regrowth', but 16 did address 'recurrence'. Not all of the included studies addressed all of our secondary outcomes (healing time, postoperative complications - infection and haemorrhage, pain of operation/postoperative pain, participant satisfaction), and two studies did not address any of the secondary outcomes.

Surgical interventions were better at preventing recurrence than non-surgical interventions with gutter treatment (or gutter removal), and they were probably better than non-surgical treatments with orthonyxia (brace treatment).

In 4 of the 12 studies in which a surgical intervention with chemical ablation (e.g. phenol) was compared with a surgical intervention without chemical ablation, a significant reduction of recurrence was found. The surgical interventions on both sides in these comparisons were not equal, so it is not clear if the reduction was caused by the addition of the chemical ablation.

In only one study, a comparison was made of a surgical intervention known as partial nail avulsion with matrix excision compared to the same surgical intervention with phenol. In this study of 117 participants, the surgical intervention with phenol was significantly more effective in preventing recurrence than the surgical intervention alone (14\% compared to $41 \%$ respectively, RR $0.34,95 \%$ CI 0.17 to 0.69$)$.

None of the postoperative interventions described, such as the use of antibiotics or manuka honey; povidone-iodine with paraffin; hydrogel with paraffin; or paraffin gauze, showed any significant difference when looking at infection rates, pain, or healing time.

\section{Authors' conclusions}

Surgical interventions are more effective than non-surgical interventions in preventing the recurrence of an ingrowing toenail.

In the studies comparing a surgical intervention to a surgical intervention with the application of phenol, the addition of phenol is probably more effective in preventing recurrence and regrowth of the ingrowing toenail. Because there is only one study in which the surgical interventions in both study arms were equal, more studies have to be done to confirm these outcomes.

Postoperative interventions do not decrease the risk of postoperative infection, postoperative pain, or healing time.

\section{PLAIN LANGUAGE S UMMARY}

\section{Treatments for ingrowing toenails}

Ingrowing toenails are a common problem and occur when the edge of the nail grows into flesh at the side of the nail, causing a painful injury. This punctured skin can become inflamed and infected.

This is an update of the Cochrane review 'Surgical treatments for ingrowing toenails'. We have broadened the scope of this review to include all types of treatment for ingrowing toenails. As well as including non-surgical treatments for ingrowing toenails, we have also looked at surgical interventions with pre- and postoperative interventions to reduce postoperative complications.

We included 24 randomised controlled trials, with a total of 2826 participants, and our aim was to determine which is the most effective treatment.

By comparison with non-surgical interventions, surgical interventions are more effective in preventing the recurrence of an ingrowing toenail.

We found that none of postoperative treatments used, such as antibiotics or manuka honey; povidone-iodine with paraffin; hydrogel with paraffin; or paraffin gauze, reduced the risk of postoperative infection or postoperative pain, or gave a shorter healing time.

Different non-surgical and surgical interventions for ingrowing toenails are available, but there is no agreement about a standard firstchoice treatment. 


\section{B A C K G R O U N D}

\section{Description of the condition}

Ingrowing toenails, also known as 'onychocryptosis' or 'unguis incarnatus', are a common problem among the general population. Most commonly, the big toe is involved, but it may also involve the lesser toes (DeLauro 2004). Ingrowing toenails occur when the periungual skin (around the nail) is punctured or traumatised by one of the distal angles of the nail plate. This results in a cycle of invasion by foreign bodies, which is sometimes followed by infection with signs of inflammation and then repair processes. The person develops a painful and draining lesion, with the formation of granulation tissue at the side of the puncture (Heidelbaugh 2009). These symptoms cause a great deal of discomfort, and they often have an impact on everyday activities (Yang 2008).

Based on clinical experience, a number of causes have been suggested, including improper trimming of the nail, tearing nails off, or wearing constricting footwear (Yang 2008). In barefoot populations, a lower incidence of onychocryptosis has been found, so it is assumed that wearing shoes is a possible risk factor (Gunal 2003). It has been suggested that thin and flattened nails increase the risk of ingrown toenails, but this has never been properly studied. Other risk factors that may increase the likelihood of ingrowing toenails are diabetes and obesity; as well as cardiac, renal, and thyroid disorders that may predispose people to lower extremity oedema (Heidelbaugh 2009). In adolescence, the feet perspire more often, causing the nail and skin to become soft. This results in nails that easily split, allowing a part of the nail to pierce the soft skin. In older people ingrowing nails are more often caused by a reduced ability to care for their nails (DeLauro 2004).

\section{Epidemiology}

The 1990 US National Health Survey reported that ingrown toenails were more common with advancing age, in women, in those earning less than $\$ 10,000$ per year, and in those living in the southern United States. Also, ingrowing toenails are reportedly less common in black people than in white people in nearly all age groups (DeLauro 2004). Based on foot type, a higher prevalence is found in people in which the first toe is shorter than the second toe. Also, in people in which the first and second toes are equal in length, but in which the first metatarsal is shorter than the second, a higher prevalence is found (Gunal 2003). In a multiethnic community-based study about prevalence of foot and ankle conditions, the most common conditions were toenail disorders (74.9\%), of which $7.4 \%$ were ingrown nails. There was no significant difference in gender or race/ethnicity (Dunn 2004). Approximately $20 \%$ of those presenting to a general practitioner with a foot problem have an ingrowing toenail (Reyzelman 2000). The Second Dutch National Survey of General Practice gives a prevalence in Dutch general practice of 54/10,000 registered patients per year, with a peak between 15 and 24 years of age (Westert 2005).

\section{Pathophysiology (natural history)}

History and physical examination reveal that the most common cause of ingrowing toenails is improper trimming of the nail. Proper toenail trimming involves cutting the nail straight across (Figure 1). When an attempt is made to round off the corners of the nails, a barb can be created that anchors itself in the soft tissue around the nail. As the nail plate grows from the matrix distally, this barb will penetrate these tissues more deeply. If the person does not seek care, the condition can become chronic. At the side of the puncture, local inflammatory processes can lead to enzymatic digestion of the offending nail portion. The inflammatory process can lead to a granuloma, and it can result in permanent hypertrophy of the nailfold. These additional soft tissue masses can create new pressures on the periungual tissues, fostering recurrence of the problem (DeLauro 2004). 
Figure I. Proper Trimming of the Toenail

\section{Proper trimming of the toenail}

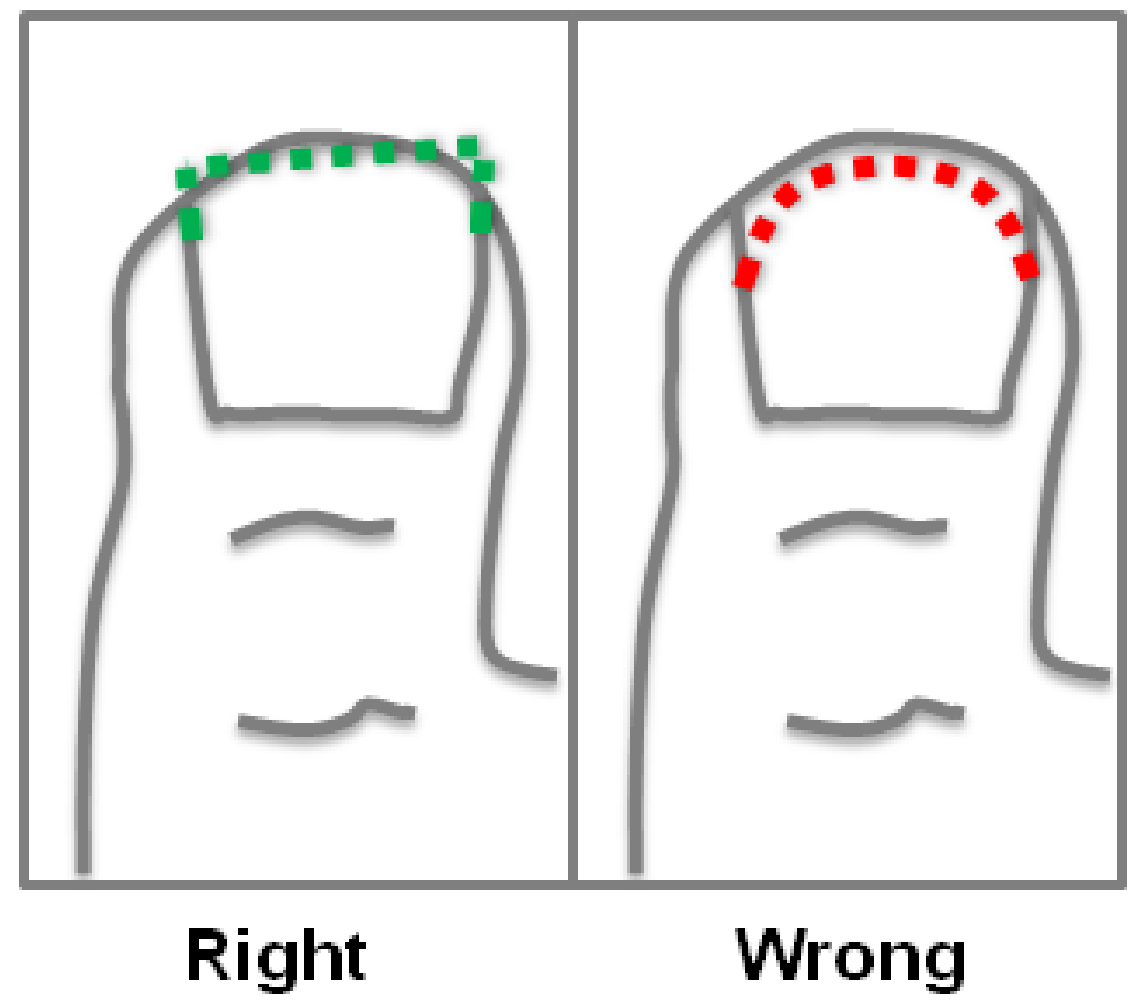

Ingrown toenails can be classified into three stages: mild (or stage I), moderate (or stage II), and severe (or stage III) (Figure 2). Mild cases are characterised by nail-fold swelling, oedema, erythema, and pain (with pressure), resulting from the puncture of the skin by the nail plate. Moderate cases are associated with the same symptoms as in mild cases, but they also lead to inflammatory granuloma tissue, accompanied by seropurulent discharge; infection; and sometimes ulceration of the nail fold. The most severe cases resemble mild and moderate cases, but they mostly exhibit chronic inflammation; the formation of epithelialised granulation tissue; and sometimes marked nail-fold hypertrophy. Indications for treatment of ingrowing toenails, therefore, include significant pain or infection or chronic, recurrent inflammation of the nail fold (DeLauro 2004; Gerritsma-Bleeker 2002). 
Figure 2. The Three Stages of Ingrown Toenails

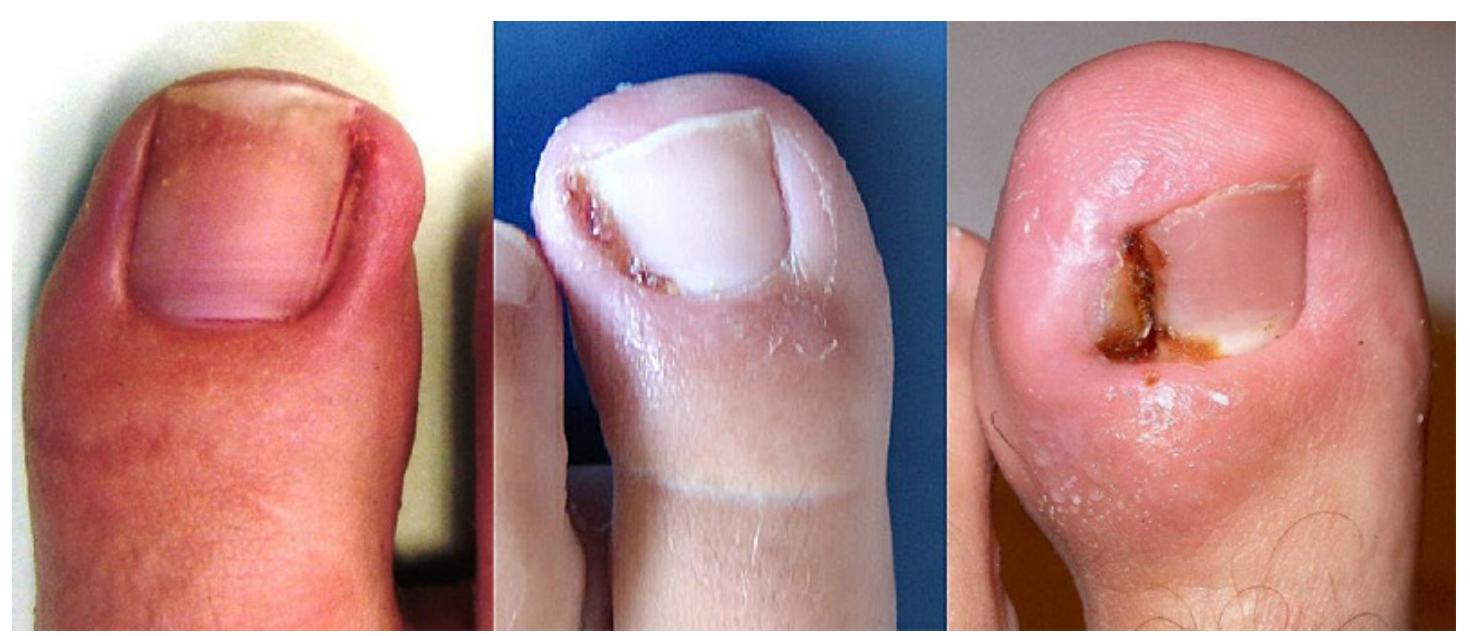

When an ingrowing toenail is presented to a physician, in almost all cases it will be treated. In general it is assumed that an ingrowing toenail is not a self-limiting problem, but it can only be cured if treated properly. When an ingrowing toenail is left untreated, stage I will develop into stage II, creating more discomfort, and it may prevent the person from carrying out their normal daily activities. Stage II will become a stage III ingrown toenail with no intervention. This results in an even more painful toe and a greater impact on the person's daily life. In the literature we found little information on the complications when an ingrown toenail is left untreated. We found only one study in which the possibility of osteomyelitis secondary to an ingrown toenail was described (Cox 1995).

\section{Description of the intervention}

A large number of interventions are used for ingrowing toenails. These can be divided in two major categories:

\section{Non-surgical (or conservative) interventions}

Non-surgical (or conservative) interventions aim to relieve symptoms, prevent the ingrown toenail getting worse, help cure the problem, and prevent recurrence (e.g. in time, repenetration of the nail fold leads again to clinical symptoms). Non-surgical interventions are most likely to be of use when the ingrowing toenail is at a mild or moderate stage of development (stage I and stage II). Gutter treatment (plastic) and orthonyxia are explained below. Many other non-surgical or conservative interventions are also available, for example, soaking the toe in warm water or placing a cotton wisp under the ingrowing nail edge (Heidelbaugh 2009).

\section{Surgical interventions}

Surgical interventions aim to remove the troublesome part of the nail (in combination with matrix destruction), thus, relieving symptoms and preventing regrowth of the nail, which prevents recurrence. Surgical interventions are most likely to be of use when the ingrowing toenail is at a more severe stage of development (stage II and stage III).

Recurrence is defined as repenetration of the nail fold over time, resulting in a repeat of clinical symptoms.

Regrowth is defined as when the (part of the) nail that has been operatively removed has returned.

There are a lot of different surgical interventions. Almost every surgical intervention aims to remove the troublesome part of the nail and destroy the underlying matrix so that there is a small risk of recurrence. The techniques used nowadays are mostly modifications of the techniques originally described by Winograd, Zadik, and Ross (Ross 1969; Winograd 1929; Zadik 1950). The nomenclature in the classification of the interventions is based on the description of the technique, instead of the names of the inventor of the technique.

The following techniques and combinations of techniques are used as surgical interventions (see below for explanations).

1. radical excision of the nail fold (also known as 'Vandenbos procedure')

2. rotational flap technique of the nail fold

3. wedge excision, wedge segmental excision, or wedge resection (also known as 'Winograd')

i) combined with application of a caustic liquid, like phenol $(\mathrm{Ph})$ or sodium hydroxide (sod)

4. total nail avulsion

i) combined with total (chemical or surgical) excision of the matrix (also known as 'Zadik')

5. partial nail avulsion (PNA, also known as 'Ross') 
i) combined with surgical (partial) matricectomy (removing the matrix of the nail)

ii) combined with chemical (partial) matricectomy with phenol $(\mathrm{Ph})$ or sodium hydroxide (sod)

iii) combined with physical (electrofulguration)

matricectomy (electrofulguration is a method of electrosurgery used to produce superficial desiccation of tissue)

\section{How the intervention might work}

\section{Non-surgical interventions}

Figure 3 relates to the following three treatments.

Figure 3. Three Non-surgical Interventions

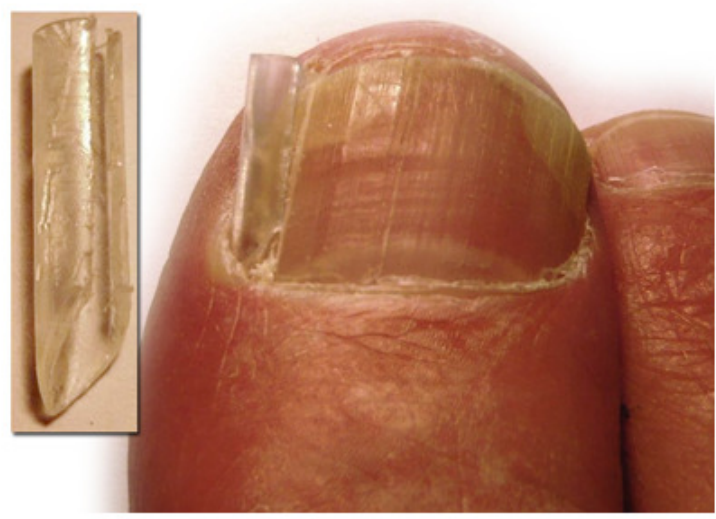

Gutter treatment

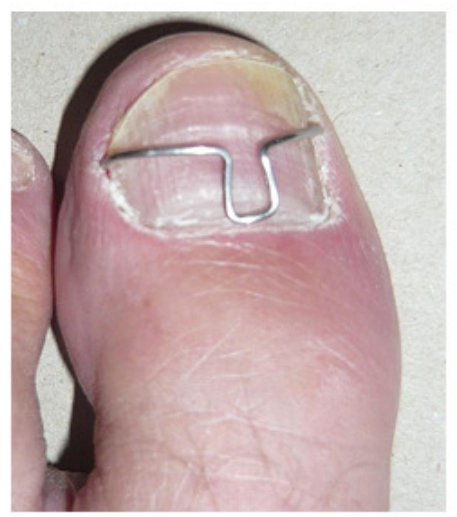

Orthonyxia

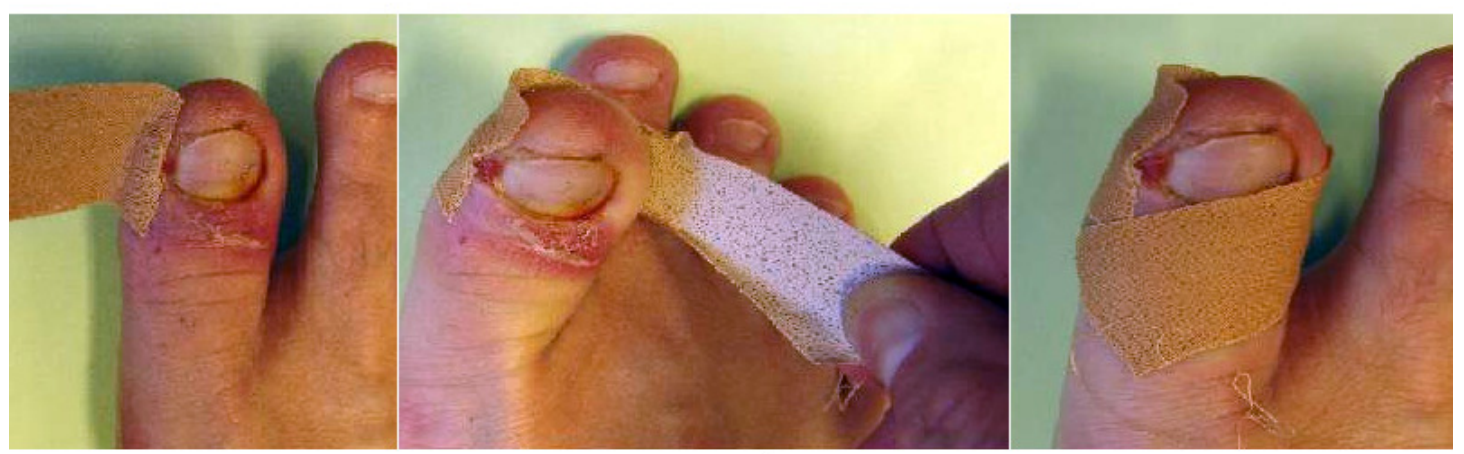

Band-aid method

\section{Gutter treatment}

With gutter treatment (also known as gutter removal or splint technique), a small vinyl or plastic tube slit from top to bottom with one end diagonally cut is placed over the ingrowing nail side, separating the nail from the nail wall, and, thus, preventing it from 
growing further into the skin. The tube can be affixed with tape or with sutures (Schulte 1998).

\section{Orthonyxia}

Orthonyxia (also known as brace treatment) is an intervention in which a small metal brace is placed on the nail after the troublesome part of the nail is removed. The metal brace has an omega shape on its highest level and U-shaped hooks on both sides. These hooks are placed around both edges of the nail, then the brace is put under tension, placed on the dorsum of the nail, and attached with gel. The aim of this intervention is relieving nail pressure on the soft tissue and correcting the nail bed deformity (Larsen 1971).

\section{Band-aid method}

With adhesive bandage, the nailfold is pulled away from the nail. The idea of this technique is that it will reduce the pressure of the nail on the edge of the nail.

\section{Surgical interventions}

The preparation for a surgical procedure is the same for almost all techniques: The affected toe is cleaned with an antiseptic, like iodine or alcohol, then a ring block anaesthetic (with lidocaine or procaine) at the base of the toe is applied. A tourniquet is applied to prevent excessive bleeding, then one of the following interventions is carried out. (With the first three techniques, the pressure of the nailplate on the nailfold is taken away by removing the nailfold. With the last two techniques, the pressure of the nailplate on the nailfold is taken away by removing (a part of) the nailplate.)

\section{Radical excision of the nail fold (no figure)}

A surgical blade is inserted vertically between the nail fold and the edge of the nail until it protrudes through the plantar surface of the toe. The blade is then pushed in distally, slicing the nail fold from the toe. The flap is then cut off at the base, leaving a raw defect, which is covered with a gauze and pressure dressing (Antrum 1984).

\section{Rotational flap technique (no figure)}

A V-shaped area is excised from the proximal nail fold, allowing rotation of the lateral nail fold to cover the exposed area after excision. Another downward incision is made on the distal end of the lateral nail fold. The whole lateral nail fold is then dissected free and retracted away from the nail bed. This allows for excision of the ingrown part of the nail plate and the related matrix. The lateral nail fold flap is then rotated upward and adjusted to the new size of the nail plate, thereby, achieving anatomical and aesthetic closure (El-Shaer 2007).

Figure 4 relates to the following three treatments. 


\section{Figure 4. Surgical Interventions}
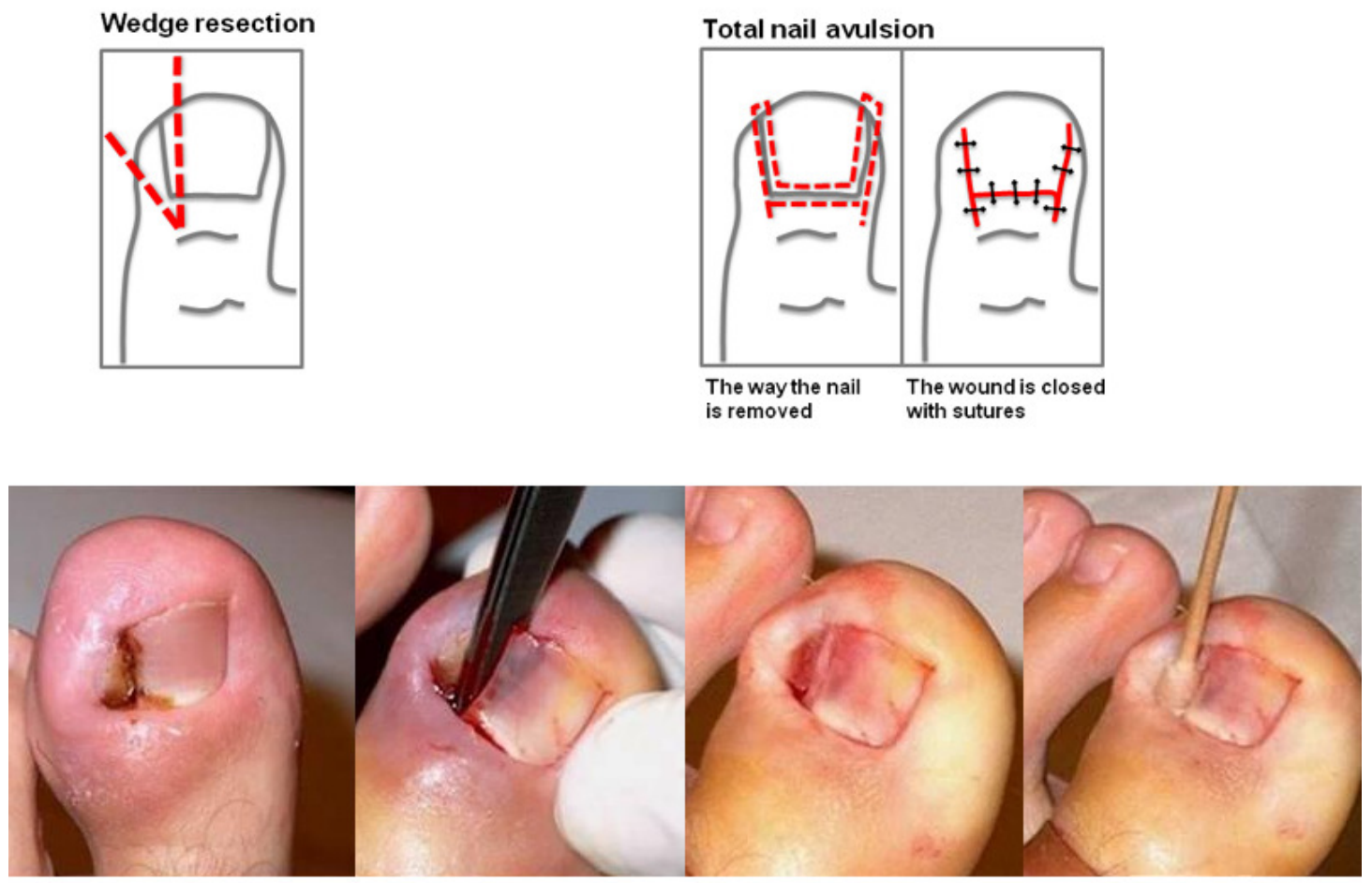

Partial nail avulsion

\section{Wedge resection}

The wedge resection was first described by Winograd; nowadays, several modifications are still used. The aim of this technique is to remove the troublesome part of the nail and the offending nail fold. A small incision in the soft tissue of the nail fold and eponychium (proximal nailfold) is made. Chiefly by blunt dissection, the soft tissue is separated from the ingrowing piece of nail until the lateral edge of the nail is reached. With small pointed scissors the nail is cut, the incision extending back to the end of the matrix. The loose piece of nail is retracted and separated from the nail bed. With a small surgical curette, the matrix and nail bed is destroyed to prevent recurrence (Winograd 1929).

\section{Total nail avulsion}

Total nail avulsion seems to be the easiest way to relieve symptoms. The whole nail is removed and, if necessary, the granuloma is excised. This technique can be combined with total excision of the underlying matrix (Zadik 1950). Excision of the matrix can be done in two different ways: by excising the matrix (surgical) with a surgical knife or scraping away the matrix, or by application of a caustic liquid (chemical), like phenol or sodium hydroxide. These liquids destroy living cells and so prevent regrowth of the nail and, thus, recurrence.

\section{Partial nail avulsion}

Partial nail avulsion was first described by Ross. Nowadays modifications of his technique are widely used in treating ingrown toenails. The aim of this technique is to remove the troublesome part of the nail. This is done by cutting down the longitudinal axis of the nail and removing the troublesome part of the nail using artery forceps (Ross 1969). This technique, similar to total nail avulsion, can be used in combination with several other techniques. Those that are most used are surgical and chemical matricectomy, which can be done in two different ways: by excising the matrix (surgical matrix excision (Surg ME)) with a surgical knife or scraping away the matrix, or by application of a caustic liquid (chemical), like phenol or sodium hydroxide. These techniques can be used 
separately, but they are also often used together. First the matrix is scraped away, and then a caustic liquid is applied to destroy the remaining matrix. Also, electrofulguration can be used as a way to destroy the underlying matrix and, so, prevent recurrence.

Surgical and chemical matricectomy are both interventions only performed in addition to a surgical intervention. They are used in addition to wedge resection, total nail avulsion, and partial nail avulsion.

For all surgical procedures, the need of a tetanus injection has to be considered.

\section{Postoperative interventions}

Several interventions to reduce postoperative complications are available. The aim of these interventions is to reduce postoperative infection or inflammation. For this review, we found several studies looking at the following postoperative interventions:

- oral or topical antibiotics before or after a surgical intervention;

- povidone-iodine with paraffin gauze after surgical intervention;

- hydrogel with paraffin gauze after surgical intervention;

- paraffin gauze after surgical intervention; and

- manuka honey dressing after surgical intervention.

\section{Why it is important to do this review}

There are several interventions for the treatment of ingrowing toenails. It is not clear which interventions give the best results when looking at recurrence, healing time, postoperative complications (e.g. infection, bleeding), and satisfaction. Although there is no consensus about a standard first-choice treatment, most physicians prefer surgical treatment over non-surgical (conservative) treatment. Surgical interventions are carried out by a wide variety of healthcare professionals, such as general practitioners, surgeons, and podiatrists. Non-surgical interventions could be effective for ingrowing toenails at stage I and maybe even at stage II, but these interventions are often overlooked, although they could provide a cost-effective approach in treatment before a surgical intervention is carried out.

The object of performing a surgical intervention on an ingrowing toenail is to cure the actual problem and to prevent its regrowth and recurrence. The object of performing a non-surgical intervention is to cure the problem and prevent recurrence, but not to prevent regrowth. Therefore, the primary outcome measures are the relief of symptoms and prevention of recurrence and/or regrowth (including nail spikes/spicules).

In this review we have evaluated different surgical and non-surgical interventions for ingrowing toenails as well as several interventions to prevent postoperative complications.

\section{O B J E C T I V E S}

To assess the effects of interventions in preventing the recurrence of ingrowing toenails.

\section{METHODS}

\section{Criteria for considering studies for this review}

\section{Types of studies}

We included randomised controlled trials for the treatment of ingrowing toenails (and for the synonyms 'unguis incarnatus' and 'onychocryptosis'). Randomised trials comparing postoperative treatment were also included. The studies must have had a followup period of at least one month.

\section{Types of participants}

We included men and women of any age who required a treatment for ingrowing toenail(s).

\section{Types of interventions}

We included all treatments for ingrowing toenails, including the following:

- surgical interventions;

- non-surgical interventions; and

- interventions to reduce postoperative complications.

\section{Types of outcome measures}

\section{Primary outcomes}

1) Relief of symptoms

2) Recurrence

3) Regrowth (including nail spicules/nail spikes)

\section{Secondary outcomes}

1) Healing time

2) Postoperative complications (infection and haemorrhage)

3) Pain of operation/postoperative pain

4) Participant satisfaction 


\section{Search methods for identification of studies}

We aimed to identify all relevant randomised controlled trials (RCTs) regardless of language or publication status (published, unpublished, in press, or in progress).

\section{Electronic searches}

For this update, we searched the following databases up to 20 January 2010:

- the Cochrane Skin Group Specialised Register using the terms (ingrow* and toenail*) or onychogryphosis or onychocryptosis or (unguis and incarnatus);

- the Cochrane Central Register of Controlled Trials (CENTRAL) in The Cochrane Library using the search strategy in Appendix 1;

- MEDLINE using the strategy in Appendix 2; and

- EMBASE using the strategy in Appendix 3.

A final prepublication search of the above databases was undertaken on 15 November 2011. We also searched the following databases up to 15 November 2011:

- CINAHL (Cumulative Index to Nursing and Allied Health Literature) using the search strategy in Appendix 4; and

- Web of Science using the search strategy in Appendix 5.

\section{Ongoing trials}

We searched the following registers of ongoing trials on 15 November 2011, using the terms 'ingrown toenail', 'ingrowing toenail', 'ingrown toenails', 'ingrowing toenails', 'onychocryptosis', and 'unguis incarnatus':

- The metaRegister of Controlled Trials (www.controlledtrials.com).

- The US National Institutes of Health Ongoing Trials Register (www.clinicaltrials.gov).

- The Australian New Zealand Clinical Trials Registry ( www.anzctr.org.au).

- The World Health Organization International Clinical Trials Registry platform (www.who.int/trialsearch).

- The Ongoing Skin Trials Register (www.nottingham.ac.uk/ ongoingskintrials).

\section{Searching other resources}

We checked the bibliographies of included and excluded studies for further references to relevant trials.

\section{Data collection and analysis}

\section{Selection of studies}

In two rounds, two authors independently ( $\mathrm{AKN}$ and $\mathrm{BvW})$ selected all randomised controlled trials that met the inclusion criteria.

In the first round, we judged whether the study focused on ingrowing toenails and if it was a randomised controlled trial. In the second round, the same authors judged the follow-up period for relief of symptoms (one month or more) and if the outcome measure met our criteria (recurrence, clinical judgement of effect, participant satisfaction, improvement of symptoms).

\section{Data extraction and management}

Two authors ( $\mathrm{BvW}$ and $\mathrm{JCvdW}$ ) extracted data independently using a pre-defined data extraction form. After comparison and reaching agreement, they entered the data into Review Manager (RevMan).

\section{Assessment of risk of bias in included studies}

Two authors (BvW and JCvdW) critically appraised the studies independently using a structured form and pre-defined standards. The studies were assessed on sequence generation, concealment of allocation, blinding, intention-to-treat analysis, baseline comparability, and completeness of follow-up (see the 'Characteristics of included studies' table and 'Risk of bias' table for each included study).

\section{Measures of treatment effect}

For dichotomous outcomes, we expressed the results as risk ratios with $95 \%$ confidence intervals $(\mathrm{Cl})$. For continuous outcomes, the results were expressed as mean differences (MD) with 95\% CI.

\section{Assessment of heterogeneity}

Heterogeneity between the studies was explored using the $\mathrm{I}^{2}$ statistic, and if substantial heterogeneity ( $\mathrm{I}^{2}$ statistic $>50 \%$ ) existed between studies for the primary outcome, reasons for heterogeneity were explored (e.g. using sensitivity analyses to examine the effects of excluding studies with lower reported methodological quality).

\section{Data synthesis}

We examined trials relevant to the focus of this review in greater detail. We provided a systematic synthesis of included trials, presenting the characteristics of trials and their results.

For studies with a similar type of intervention, we carried out meta-analyses to calculate a weighted treatment effect across trials using a random-effects model (DerSimonian and Laird model). When studies had more than two arms, we conducted pair-wise analyses. When data from these studies could be pooled, we adjusted the size of the study groups by dividing by the number of arms. 


\section{Sensitivity analysis}

We carried out sensitivity analyses in two instances: Where we were looking at the outcome 'recurrence' in a comparison of nonsurgical and surgical treatments, we excluded a study without gutter treatment, and where we were looking at the outcome 'postoperative infection', we excluded incomparable surgery.

\section{R E S U L T S}

\section{Description of studies}

See: Characteristics of included studies; Characteristics of excluded studies; Characteristics of studies awaiting classification; Characteristics of ongoing studies.

\section{Results of the search}

With our sensitive search we found 982 articles about ingrowing toenails. For 401 of these, based on the title or abstract, we could not exclude the possibility that it was a RCT, and we requested a printed article.

Forty-five studies matched our first selection criteria for possible inclusion in the review. From these, 24 matched our second selection criteria and were included in the review, 18 were excluded, 1 study is awaiting assessment, and 2 are ongoing.

\section{Included studies}

Twenty-four studies met the inclusion criteria, with a total number of 2826 participants (Anderson 1990; Arista 2006; Beck 1984; Bos 2006; Dovison 2001; Flores 2006; Gem 1990a; Gem 1990b; Gerritsma-Bleeker 2002; Greig 1991a; Issa 1988; Kim 2003; Kruijff 2008; Leahy 1990; McIntosh 2006; Morkane 1984; Perry 1984; Reyzelman 2000; Shaath 2005; Sykes 1988b; Sykes 1988c; van der Ham 1990; Varma 1983; Wallace 1979b). Three of these studies were about interventions to reduce postoperative complications (Dovison 2001; McIntosh 2006; Reyzelman 2000). Please see the 'Characteristics of included studies' tables for details.

In the previous review, nine studies were included. In this update, 7 of the 24 included studies were also included in the previous review (Anderson 1990; Greig 1991a; Issa 1988; Leahy 1990; Morkane 1984; van der Ham 1990; Varma 1983). The two studies that were part of the previous review, but which we did not include, were quasi-randomised (Andrew 1979; Tait 1987). Seven of our 24 included studies were found when a search was run (October 2002) prior to publication of the review 'Surgical treatments for ingrowing toenails' by Rounding 2003. They were not fully incorporated into that review.

In our analysis, we ignored the fact that in some studies participants could contribute more than one toenail: Firstly, because several of these studies only reported outcomes per participant, not per toenail. Secondly, because in most of these studies the number of participants with more than one contributing toenail was small.

\section{Design}

All studies were parallel studies expect for one (Beck 1984), which was a within-patient trial. The studies were divided into two, three, or even four treatment arms: Two studies had four groups (Bos 2006; Perry 1984), and two had three groups (Dovison 2001; Issa 1988).

\section{Sample sizes}

The 24 included studies had a median number of 118 participants. The samples sizes in the studies varied from 31 to 424 participants (mean 111)

\section{Setting}

All studies were hospital-based.

\section{Participants}

Six studies did not report their inclusion and exclusion criteria (Issa 1988; Kim 2003; Perry 1984; Sykes 1988b; Sykes 1988c; Varma 1983).

Only two studies reported their inclusion criteria (Leahy 1990; Shaath 2005). The remaining studies reported both their inclusion and exclusion criteria. Three studies (Greig 1991a; Morkane 1984; van der Ham 1990) excluded participants who had had previous toenail surgery, and one study (Anderson 1990) only included participants who had previously had two or more surgical procedures on their toenail.

\section{Interventions}

Of our 24 included studies examining the effect of a total of 25 different interventions for ingrowing toenails, 5 examined nonsurgical interventions, 16 examined surgical interventions, and 4 examined postoperative interventions.

We found five studies about non-surgical interventions: Two studies described orthonyxia (Beck 1984; Kruijff 2008), and three studies described (plastic) gutter treatment (Kim 2003; Perry 1984; Wallace 1979b). We did not find any studies about the band-aid technique. Three studies compared non-surgical interventions with surgical interventions (Kruijff 2008; Perry 1984; Wallace 1979b), one study compared two non-surgical interventions (Beck 1984), and one study compared treatment duration of a non-surgical intervention (Kim 2003).

We found 18 studies about surgical interventions: 3 compared any surgical intervention with any other surgical intervention (Bos 2006; Greig 1991a; Perry 1984), 16 added the use of a caustic 
liquid to a surgical intervention and compared this to the surgical intervention alone (Anderson 1990; Arista 2006; Bos 2006; Gem 1990a; Gem 1990b; Gerritsma-Bleeker 2002; Greig 1991a; Issa 1988; Leahy 1990; Morkane 1984; Reyzelman 2000; Shaath 2005; Sykes 1988b; Sykes 1988c; van der Ham 1990; Varma 1983), 1 study added the use of electrofulguration to a surgical intervention (Flores 2006), and 1 study compared 2 different surgical interventions both with the addition of phenol (Issa 1988). The shortest follow-up period for recurrence was six months. Four studies were about different pre- and postoperative interventions to reduce postoperative complications: Two studies compared pre- and postoperative use of antibiotics following surgical intervention (Bos 2006; Reyzelman 2000), and the other two studies compared different postoperative interventions, e.g. different types of gauze (Dovison 2001; McIntosh 2006).

For most comparisons, we found only one study for inclusion. We found more studies eligible for inclusion for the following comparisons: phenol and partial avulsion versus wedge/segmental excision (five studies), phenol and partial avulsion versus total avulsion (two studies), and phenol and partial avulsion versus partial matrix excision (two studies).

\section{Outcomes}

The outcomes measured in these studies varied. Almost all studies had recurrence as an outcome measure, but seven studies did not measure recurrence (Arista 2006; Beck 1984; Dovison 2001; Flores 2006; McIntosh 2006; Reyzelman 2000; Wallace 1979b). Six studies used infection as an outcome measure (Anderson 1990; Bos 2006; Greig 1991a; Leahy 1990; McIntosh 2006; Reyzelman 2000), and 10 studies measured postoperative pain (Arista 2006; Flores 2006; Gem 1990a; Gem 1990b; Issa 1988; Kim 2003; McIntosh 2006; Morkane 1984; Shaath 2005; Wallace 1979b). Two of these studies measured postoperative pain in the use of analgesics (Arista 2006; van der Ham 1990). Four studies also used postoperative haemorrhage as an outcome measure (Arista 2006; Flores 2006; Kruijff 2008; Leahy 1990), 10 studies had healing time as an outcome measure (Arista 2006; Dovison 2001; Flores 2006; Gem 1990a; Gem 1990b; McIntosh 2006; Perry 1984; Reyzelman 2000; van der Ham 1990; Varma 1983), and 3 studies used participant satisfaction as an outcome measure (Anderson 1990; Beck 1984; Greig 1991a).

Some studies used postoperative erythema/redness and exudate as an outcome measure (Flores 2006; Gerritsma-Bleeker 2002; Kruijff 2008). Because this is not an objective outcome for infection, we decided not to include these outcomes in the review. Only data from studies that reported on infection were included. Also, Arista 2006, Gerritsma-Bleeker 2002, and Shaath 2005 reported on healing time, but classified this outcome measure as returning to work or daily activities, returning to hobbies or sports, and problems with shoe wear. Furthermore, Gerritsma-Bleeker 2002 reported on participant satisfaction, but classified this using a scar, symptoms, and cosmetic score. Three studies had a loss to follow up larger than 20\% (Gem 1990a; Gem 1990b; Shaath 2005).

We ignored the fact that in seven studies (Gerritsma-Bleeker 2002; Greig 1991a; Issa 1988; Kruijff 2008; Morkane 1984; Perry 1984; van der Ham 1990) participants could contribute more than one toenail, because several of these studies only reported outcomes per participant, not per toenail. Also, in most of these studies the number of participants with more than one contributing toenail was small.

\section{Excluded studies}

We excluded 18 studies after the second selection. See the 'Characteristics of excluded studies' tables for details.

Three studies were not about ingrowing toenails (Boberg 2002; Foley 1994; Holt 1987); two studies did not compare interventions (Greig 1991b; Sykes 1988a). Four studies were not randomised controlled trials (Aksahal 2001; Arai 2004; Schütte 1980; Tada 2004). Seven studies were quasi-randomised (Andrew 1979; Bossers 1992; Bostanci 2007; Burssens 1987; Herold 2001; Kocyigit 2005; Tait 1987), and one study had a follow-up period shorter than one month (Córdoba-Fernandez 2008). One study allocated the participants based on the stage of the ingrown toenail, therefore, introducing bias (Cameron 1981).

\section{Studies awaiting classification}

One study is awaiting clarification and data from the authors (Zaba 2002). Because it is an abstract, the methodology is not adequately described, and it is not clear whether randomisation was adequate. Therefore, the study could not be definitely excluded until this is clarified.

In November 2011, three studies were found (Altinyazar 2010; Peyvandi 2011; Tatlican 2009), which are awaiting classification. These will be incorporated in the next update of this review.

\section{Ongoing studies}

We found two ongoing studies (ISRCTN32883274; NCT00641433). We attempted to contact the authors, but this was not successful. It is unclear if these trials are complete and whether they have been published.

\section{Risk of bias in included studies}

We used the Cochrane Collaborations' recommended tool for assessing risk of bias (Higgins 2008) and assessed 10 domains for each study (see the 'Characteristics of included studies' tables). We summarised the 'Risk of bias' tables into the review authors' judgements about each methodological quality item for each included study (Figure 5) and a methodological quality graph (Figure 6), 
which gives the review authors' judgements about each methodological quality item presented as percentages across all included studies.

Figure 5. 'Risk of bias' table: Review authors' judgements about each methodological quality item for each included study.

\begin{tabular}{|c|c|c|c|c|c|c|c|c|c|}
\hline & 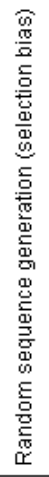 & 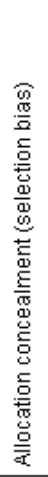 & 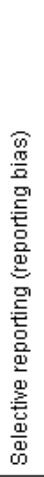 & 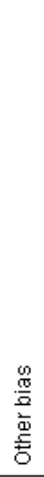 & 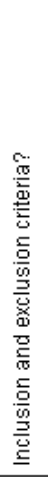 & 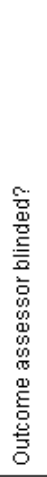 & 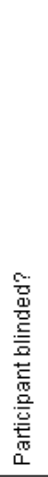 & 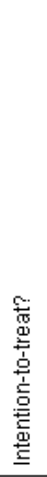 & 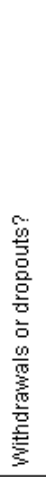 \\
\hline Anderson 1990 & $?$ & $?$ & $?$ & + & + & + & 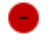 & + & + \\
\hline Arista 2006 & $?$ & $?$ & $?$ & $?$ & 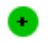 & - & & $\oplus$ & $\odot$ \\
\hline Beck 1984 & $?$ & + & $?$ & $?$ & + & - & & & $\odot$ \\
\hline Bos 2006 & $?$ & $?$ & $?$ & $?$ & + & + & & & $\odot$ \\
\hline Dovison 2001 & $?$ & $?$ & $?$ & $?$ & + & $?$ & & & \\
\hline Flores 2006 & $?$ & $?$ & $?$ & $?$ & + & ? & & $\oplus$ & $\odot$ \\
\hline Gem 1990a & $?$ & $?$ & $?$ & $?$ & + & $?$ & & & \\
\hline Gem 1990b & $?$ & $?$ & $?$ & $?$ & + & $?$ & & & \\
\hline Gerritsma-Bleeker 2002 & $?$ & ? & ? & $\odot$ & + & + & & & $\odot$ \\
\hline Greig 1991a & $?$ & ? & $?$ & $?$ & + & + & & & \\
\hline Issa 1988 & + & $?$ & $?$ & + & - & $?$ & & & \\
\hline Kim 2003 & $?$ & $?$ & $?$ & $?$ & 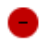 & $?$ & & + & 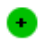 \\
\hline Kruijff 2008 & $?$ & $?$ & $?$ & + & + & + & & & \\
\hline Leahy 1990 & $?$ & $?$ & $?$ & + & 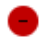 & + & & & \\
\hline McIntosh 2006 & $?$ & + & $?$ & + & + & + & + & & $\odot$ \\
\hline Morkane 1984 & $?$ & $?$ & $?$ & ? & + & ? & & + & + \\
\hline Perry 1984 & $?$ & $?$ & $?$ & $?$ & C & $?$ & & + & \\
\hline Reyzelman 2000 & 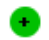 & $?$ & $?$ & $?$ & + & $?$ & & & \\
\hline Shaath 2005 & $?$ & + & $?$ & $?$ & + & + & & & \\
\hline Sykes 1988b & $?$ & $?$ & $?$ & $?$ & & $?$ & & $?$ & \\
\hline Sykes $1988 \mathrm{c}$ & $?$ & $?$ & $?$ & - & & $?$ & & & \\
\hline van der Ham 1990 & $?$ & $?$ & $?$ & ? & + & - & & + & \\
\hline Varma 1983 & $?$ & $?$ & $?$ & $?$ & 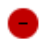 & - & & & \\
\hline Wallace $1979 b$ & $?$ & $?$ & $?$ & $?$ & + & + & & + & + \\
\hline
\end{tabular}


Figure 6. Methodological quality graph: Review authors' judgements about each methodological quality item presented as percentages across all included studies.

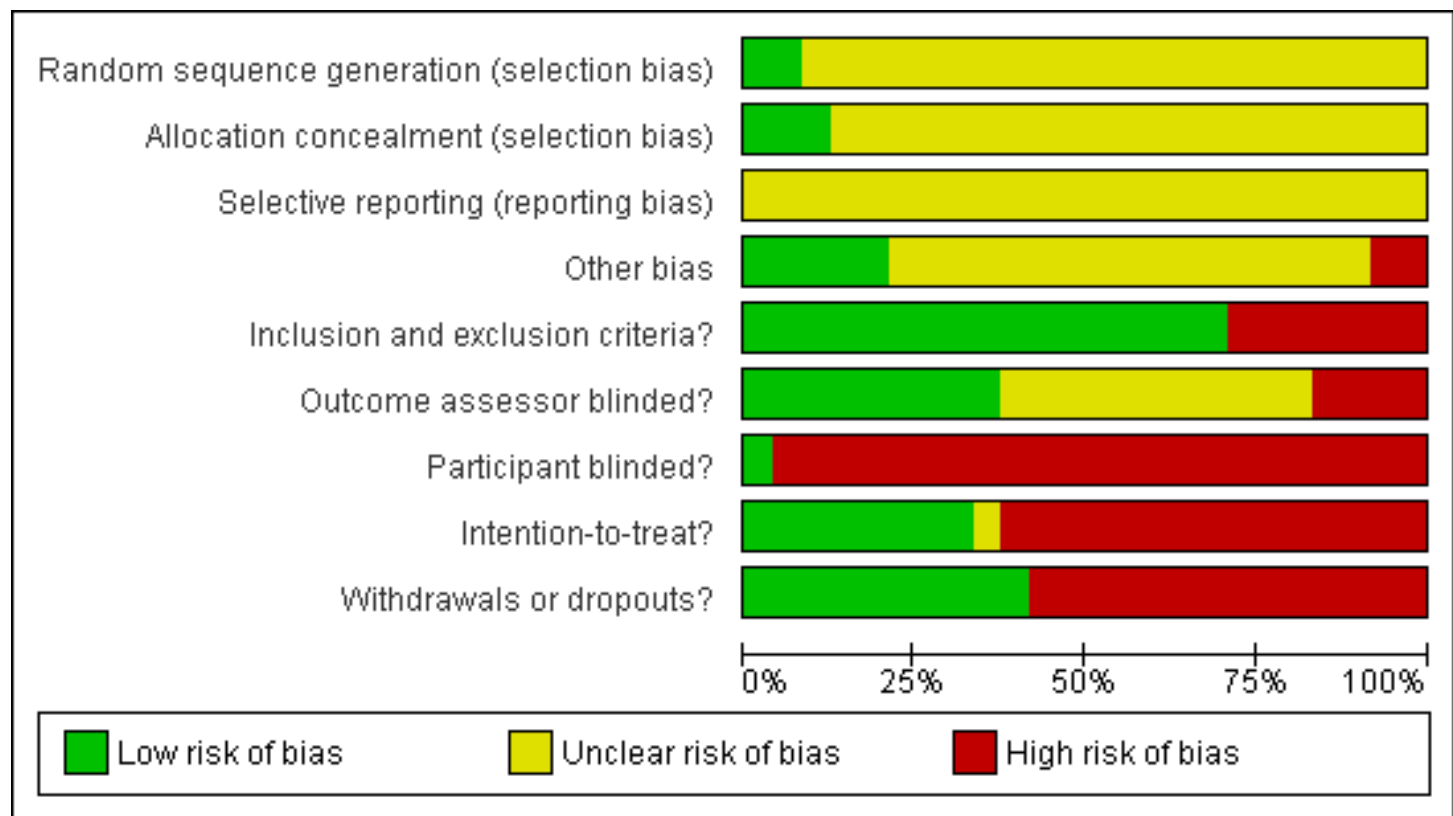

If the method of randomisation was not mentioned in the article, we contacted the authors. Depending on the additional information provided about the method of randomisation, the study was included or excluded. Studies from authors who did not respond were still included in the review, although the method of randomisation was not known.

\section{Allocation}

All of the included studies were described as randomised.

We classed all of the studies as at an unclear risk of bias, except two (Issa 1988; Reyzelman 2000). These used random number generation, which we classed as at low risk of bias. Nine studies were randomised using (prearranged) sealed envelopes (Beck 1984; Bos 2006; Gerritsma-Bleeker 2002; Kruijff 2008; Leahy 1990; Shaath 2005; van der Ham 1990; Varma 1983; Wallace 1979b), and one used remote randomisation via a telephone call to an independent assistant (McIntosh 2006). Twelve studies stated that they randomised the participants, but they did not specify the method that was used (Anderson 1990; Arista 2006; Dovison 2001; Flores 2006; Gem 1990a; Gem 1990b; Greig 1991a; Kim

2003; Morkane 1984; Perry 1984; Sykes 1988b; Sykes 1988c). In three studies, we judged allocation concealment to be satisfactory, and we classed these as at a low risk of bias (Beck 1984; McIntosh 2006; Shaath 2005).

\section{Blinding}

Due to the nature of the interventions, it was not possible to blind the caregiver to the procedure, so none of the included studies blinded the caregiver to the intervention. Therefore, we decided not to include this item in the 'Risk of bias' assessment. Blinding the participant to the procedure was done in one study (McIntosh 2006), which we judged to be at low risk of bias; no other included study attempted to do this.

Nine studies (Anderson 1990; Bos 2006; Gerritsma-Bleeker 2002; Greig 1991a; Kruijff 2008; Leahy 1990; McIntosh 2006; Shaath 2005; Wallace 1979b) used an independent observer to evaluate the intervention, which we judged to be at low risk of bias. Four studies were judged as high risk (Arista 2006; Beck 1984; van 
der Ham 1990; Varma 1983). The other studies did not state if the evaluation of the intervention was done by an independent observer, so we classed these as at unclear risk of bias.

\section{Incomplete outcome data}

Six of the 24 included studies had no dropouts or withdrawals and provided an intention-to-treat analysis (Anderson 1990; Arista 2006; Flores 2006; Kim 2003; Morkane 1984; Wallace 1979b). Four studies were also low risk because details were given about the loss to follow up (Beck 1984; Bos 2006; Gerritsma-Bleeker 2002; McIntosh 2006). Two studies provided an intention-to-treat analysis (Perry 1984; van der Ham 1990), but without clear information about withdrawals or dropouts.

All 14 other studies were judged as high risk of bias because no reasons were given. Of these, 2 studies had a loss to follow up larger than 5\%, but less than 10\% (Dovison 2001; Varma 1983), and 6 studies had a loss to follow up of 5\% or less (Greig 1991a; Issa 1988; Kruijff 2008; Leahy 1990; Reyzelman 2000; van der Ham 1990). In one study, no information was given about the number lost of follow up (Sykes 1988b). The remaining 5 studies had losses to follow up of 15\% (Perry 1984),19\% (Sykes 1988c), 21\% (Shaath 2005), 28\% (Gem 1990a), and 42\% (Gem 1990b), respectively.

\section{Selective reporting}

None of the studies reported about possible selective reporting, so we classed them all as unclear risk of bias.

\section{Other potential sources of bias}

In seven studies, no information was given about the inclusion and exclusion criteria (Issa 1988; Kim 2003; Leahy 1990; Perry 1984; Sykes 1988b; Sykes 1988c; Varma 1983) so we classed these as at high risk of bias. In all other studies, information was given about inclusion and exclusion criteria, so we classed these as at low risk of bias.

In two studies, there was a potential risk of other bias (GerritsmaBleeker 2002; Sykes 1988c) (see the 'Characteristics of included studies' tables). In four studies, there was a low risk of other bias because there was no baseline imbalance (Issa 1988; Kruijff 2008; Leahy 1990; McIntosh 2006), and one other study was also classed as at low risk of bias (Anderson 1990) because, although there was an imbalance for sex and age, we judged this to be without risk of bias.

\section{Effects of interventions}

We have discussed the primary and secondary outcomes under the following comparisons:

- Non-surgical procedures
- Non-surgical interventions with or without pre- or postoperative treatment versus (vs) non-surgical interventions with or without pre- or postoperative treatment

- Non-surgical vs surgical procedures

- Surgical procedures

- Chemical ablation and surgery vs surgical procedures

- Different types of surgical procedures

- Chemical ablation and partial avulsion vs chemical ablation and surgery

- Surgery with electrofulguration vs surgery

- Pre- and postoperative procedures

\section{Primary outcomes}

1) Relief of symptoms

2) Recurrence

3) Regrowth (including nail spicules/nail spikes)

None of the included studies addressed our primary outcomes of 'relief of symptoms' or 'regrowth', but 16 did address 'recurrence' (Anderson 1990; Bos 2006; Gem 1990a; Gem 1990b; GerritsmaBleeker 2002; Greig 1991a; Issa 1988; Kim 2003; Kruijff 2008; Leahy 1990; Reyzelman 2000; Shaath 2005; Sykes 1988b; Sykes 1988c; van der Ham 1990; Varma 1983).

\section{Secondary outcomes}

1) Healing time

2) Postoperative complications (infection and haemorrhage)

3) Pain of operation/postoperative pain

4) Participant satisfaction

Not all of the included studies addressed all of our secondary outcomes, and two studies did not address any of the secondary outcomes (Sykes 1988b; Sykes 1988c).

Arista 2006, Dovison 2001, Flores 2006, McIntosh 2006, Perry 1984, Reyzelman 2000, van der Ham 1990, and Varma 1983 reported on 'healing time'.

Flores 2006, Greig 1991a, Kruijff 2008, Leahy 1990, and Reyzelman 2000 reported on 'postoperative infection and haemorrhage'.

Arista 2006, Flores 2006, Gerritsma-Bleeker 2002, Issa 1988, Kim 2003, Leahy 1990, McIntosh 2006, Morkane 1984, van der Ham 1990, and Wallace 1979b reported on 'postoperative pain'.

Anderson 1990, Beck 1984, Greig 1991a, and Leahy 1990 reported on 'participant satisfaction'.

\section{Primary outcome:}

\section{2) Recurrence}

Non-surgical procedures 


\section{Non-surgical interventions with or without pre- or postoperative treatment vs non-surgical interventions with or without pre- or postoperative treatment}

There was no significant difference in the risk of recurrence after 12 months when gutter removal (a non-surgical intervention without pre- or postoperative treatment) after 3 days was compared with gutter removal (another non-surgical intervention without pre- or postoperative treatment) after 2 weeks, in the study by Kim 2003 (RR 0.69, 95\% CI 0.12 to 3.83) (see Analysis 1.1).

\section{Non-surgical vs surgical procedures}

In three studies, non-surgical interventions were compared to surgical interventions. We chose not to show totals because of the different nature of the studies.

For 2 of the studies (Perry 1984; Wallace 1979b) in which the non-surgical intervention with gutter treatment was compared to surgical treatment (we pooled the 2 control surgical groups), surgical treatment was significantly more effective at preventing recurrence (RR 0.63, 95\% CI 0.47 to 0.85 ) (see Analysis 2.1). The bigger study did not find a significant difference (Perry 1984). In 1 study (Kruijff 2008), there was no significant difference in recurrence when non-surgical treatment with orthonyxia was compared to surgical treatment (RR 0.89, 95\% CI 0.77 to 1.04 ) (see Analysis 2.1).

We did a sensitivity analysis for Analysis 2.1; $\mathrm{I}^{2}$ statistic was $81 \%$. Excluding the study without gutter treatment (Kruijff 2008) dramatically reduced this $\left(\mathrm{I}^{2}\right.$ statistic $\left.=0 \%\right)$. The total effect for this subgroup of studies was 0.57 ( 0.47 to 0.67$)(\mathrm{P}=0.00001)$.

\section{Surgical procedures}

\section{Chemical ablation and surgery vs surgical procedures}

In 4 of the 12 studies in which a surgical intervention with chemical ablation was compared with a surgical intervention without chemical ablation, there was a significant reduction of recurrence in favour of chemical ablation (RR $0.25,95 \%$ CI 0.09 to 0.69 Morkane 1984; RR 0.12, 95\% CI 0.06 to 0.27 - Greig 1991a; RR $0.09,95 \%$ CI 0.05 to 0.17 - Sykes 1988c; RR 0.26, 95\% CI 0.12 to 0.53 - Shaath 2005) (see Analysis 3.1). However, the surgical interventions on both sides in these comparisons were not equal, so it is not clear if the reduction was caused by the addition of the chemical ablation. The observation period of the studies in which recurrence was reported was 6 to 30 months.

Sykes $1988 \mathrm{~b}$ only reported on the overall percentage of recurrences (14\%) without specifying this by treatment group.

In one study, a comparison was made with a surgical intervention with matrix excision, referred to as PNA (partial nail avulsion), compared to the same surgical intervention with phenol (Bos
2006). The outcome of 'recurrence at one year' was presented for the 'no antibiotic' and for the 'antibiotic' group. We took both groups ('no antibiotic' and 'antibiotic') together because we presumed that antibiotic application after the surgical intervention had no effect on recurrence. In this study (Bos 2006), there were 123 participants, but 6 were lost to follow up: 5 from the PNA with phenol group, leaving 58 participants, and 1 from the PNA-alone group, leaving 59 participants. PNA with phenol was significantly more effective than PNA alone (RR 0.34, 95\% CI 0.17 to 0.69 ) (see Analysis 3.1).

\section{Different types of surgical procedures}

The study by Greig 1991a showed there was no significant difference in prevention of recurrence when nail edge excision (SurgProc A) was compared with total avulsion of the nail (SurgProc B) (RR 1.01, 95\% CI 0.82 to 1.24) (see Analysis 4.1).

The study by Perry 1984 showed wedge resection (SurgProc A) was significantly better after 12 months in preventing recurrence than the more invasive rotational flap technique (SurgProc B) (RR $0.19,95 \%$ CI 0.05 to 0.80 ) (see Analysis 4.1). Also, radical excision of the nail fold (SurgProc A) was significantly better after 12 months in preventing recurrence than the rotational flap technique (SurgProc B) (RR 0.17, 95\% CI 0.04 to 0.72) (see Analysis 4.1). There was no significant difference after 12 months in prevention of recurrence between wedge resection (SurgProc A) and radical excision of the nail fold (SurgProc B) (RR 1.13, 95\% CI 0.17 to 7.53 ) (see Analysis 4.1).

\section{Chemical ablation and partial avulsion vs chemical ablation and surgery}

One study (Issa 1988), in which phenol with partial nail avulsion $(\mathrm{PNA}+\mathrm{Ph}$ ) was compared to phenol and wedge resection (wedge $+\mathrm{Ph}$ ), found no significant difference in recurrence after 6 months (RR 10.50, 95\% CI 0.58 to 190.65) (see Analysis 5.1). Also, no significant difference was seen after 12 months when sodium hydroxide was added to partial nail avulsion (PNA + Sod, recurrence $13 \%)$ compared to phenol and partial nail avulsion (PNA $+\mathrm{Ph}$, recurrence $8 \%$ ) (RR 0.61, 95\% CI 0.24 to 1.57 - Gem 1990a) (RR 1.35, 95\% CI 0.40 to 4.55 - Gem 1990b) (see Analysis 5.1).

\section{Surgery with electrofulguration vs surgery}

We did not find any study which addressed our primary outcomes when surgery with electrofulguration was compared to surgery alone. 


\section{Pre- and postoperative procedures}

There was a significant difference seen after 12 months in recurrence in the study by Bos 2006, when partial nail avulsion with matrix excision and application of antibiotic (PNA + surg ME + $\mathrm{AB})$ was compared with partial nail avulsion with application of phenol and antibiotic (PNA + Ph + AB) (RR 9.52, 95\% CI 1.29 to 70.11) (see Analysis 7.1) in favour of phenol and antibiotic. In this comparison, it is likely that the significant difference is due to the nature of the intervention and not due to the addition of antibiotics.

In the following comparisons, there was no significant difference in recurrence between the two postoperative procedures: when partial nail avulsion with matrix excision and application of antibiotic (PNA + surg $\mathrm{ME}+\mathrm{AB})$ was compared with partial nail avulsion with matrix excision (PNA + surg ME) (RR 0.90, 95\% CI 0.47 to 1.75 ) (see Analysis 8.1), when partial nail avulsion with matrix excision and antibiotic (PNA + surg $\mathrm{ME}+\mathrm{AB}$ ) was compared with partial nail avulsion with phenol (PNA + Ph) $(\mathrm{RR} 1.80,95 \% \mathrm{CI}$ 0.76 to 4.22) (see Analysis 9.1), and when partial nail avulsion with application of phenol and antibiotic (PNA $+\mathrm{Ph}+\mathrm{AB})$ was compared with partial nail avulsion with application of phenol $(\mathrm{PNA}+\mathrm{Ph})(\mathrm{RR} 0.19,95 \%$ CI 0.02 to 1.44$)$ (see Analysis 10.1). When partial nail avulsion with phenol plus antibiotic (PNA $+\mathrm{Ph}$ $+\mathrm{AB}$ ) was compared with partial nail avulsion with matrix excision (PNA + surg ME), the former intervention was significantly less likely to result in recurrence at 12 months (RR $0.10,95 \%$ CI 0.01 to 0.67 ) (see Analysis 11.1).

However, it must be borne in mind with Analysis 7.1 and Analysis 11.1 that it is not likely that a pre- or postoperative intervention can reduce regrowth or risk of recurrence.

\section{Secondary outcomes}

We have addressed these outcomes under the same intervention headings as before.

\section{I) Healing time}

\section{Surgical procedures}

\section{Chemical ablation and surgery vs surgical procedure}

van der Ham 1990, Perry 1984, and Varma 1983 reported on healing time, but they provided insufficient data to enable analyses for this outcome measure. van der Ham 1990 found no significant difference in mean healing time between partial avulsion with phenol (PNA $+\mathrm{Ph}$ ) and wedge excision (2.2 weeks vs 2.5 weeks), and Varma 1983 also found no significant difference between wedge excision with and without phenol ( 2 weeks vs 2 weeks). Perry 1984 found no significant differences in mean healing time for wedge excision, radical excision of the nailfold, and plantar rotation of the nailfold.

\section{Surgery with electrofulguration vs surgery}

Flores 2006 reported on healing time (healed after 14 days with oral antibiotics $65 \%$ and with local antibiotics $42 \%$ ), but did not provide standard deviations; therefore, we could not use the data.

\section{Pre- and postoperative procedures}

In the study by Dovison 2001, there was no significant difference in healing time when comparisons were made between the postoperative use of gauzes with manuka honey, povidone-iodine with paraffin, hydrogel with paraffin, or paraffin gauze alone (see Analysis 7.4).

In the study by Reyzelman 2000, there was no significant difference in healing time when a surgical intervention (partial nail avulsion with phenol) with 1 week of antibiotic afterwards (PNA $+\mathrm{Ph}+\mathrm{AB}$ after) was compared with a surgical intervention (PNA $+\mathrm{Ph}$ ) (MD -0.10, 95\% CI -0.40 to 0.20 ) (see Analysis 10.3), or when surgical intervention with 1 week's antibiotic in advance (PNA $+\mathrm{Ph}+\mathrm{AB}$ advance) was compared with surgical intervention without antibiotic (PNA + Ph) (MD 0.30, 95\% CI -0.02 to 0.62) (see Analysis 13.2).

There was a significant difference in healing time in favour of antibiotics after treatment, when surgical intervention with 1 week's antibiotic in advance ( $\mathrm{PNA}+\mathrm{Ph}+\mathrm{AB}$ advance) was compared with surgical intervention with 1 week's antibiotic afterwards (PNA + $\mathrm{Ph}+\mathrm{AB}$ afterwards) (MD 0.40, 95\% CI 0.11 to 0.69 ) (see Analysis 12.1).

2) Postoperative complications (infection and haemorrhage)

\section{Surgical procedures}

\section{Chemical ablation and surgery vs surgical procedure}

In 4 studies (Anderson 1990; Bos 2006; Greig 1991a; Leahy 1990), phenol did not significantly increase the postoperative infection rate (RR 1.51, 95\% CI 0.53 to 4.34) (see Analysis 3.3). (In a sensitivity analysis of Analysis 3.3, excluding incomparable surgery did not reduce the $\mathrm{I}^{2}$ statistic.)

In the study by Greig 1991a, no significant difference was found in postoperative infection between those undergoing nail edge excision compared to total nail avulsion (RR 3.75, 95\% CI 0.16 to 90.00) (see Analysis 4.3). 
For postoperative haemorrhage, 2 studies (Arista 2006; Leahy 1990) showed no significant difference between partial nail avulsion and phenol $(\mathrm{PNA}+\mathrm{Ph})$ compared to wedge resection and matrix excision (wedge + surg ME) (RR 1.18, 95\% CI 0.08 to 18.24) (see Analysis 3.4), and partial nail avulsion and phenol (PNA $+\mathrm{Ph}$ ) compared to partial nail avulsion and matrix excision (PNA + surg ME) (RR 0.38, 95\% CI 0.08 to 1.67) (see Analysis 3.4).

\section{Pre- and postoperative procedures}

There was no significant difference in postoperative infection when partial nail avulsion with matrix excision and antibiotics (PNA + surg $\mathrm{ME}+\mathrm{AB})$ were compared with partial nail avulsion with phenol and antibiotics (PNA $+\mathrm{Ph}+\mathrm{AB}$ ) in the study by Bos 2006. Nor was there a significant difference in postoperative infection when manuka honey was compared with paraffin-impregnated tulle gras (McIntosh 2006), when hydrogel with paraffin gauze was compared with paraffin gauze only, or when povidoneiodine with paraffin gauze was compared with paraffin gauze only or with hydrogel with paraffin gauze (Dovison 2001) (see Analysis 7.2).

None of the following comparisons in the study by Bos 2006 showed a significant difference in postoperative infection: partial nail avulsion with matrix excision and antibiotics (PNA + surg $\mathrm{ME}+\mathrm{AB})$ compared with partial nail avulsion with matrix excision (PNA + surg ME) (RR 0.95, 95\% CI 0.55 to 1.65 ) (see Analysis 8.2), partial nail avulsion with matrix excision and antibiotics (PNA + surg ME + AB) compared with partial nail avulsion with phenol (PNA + Ph) (RR 0.83, 95\% CI 0.48 to 1.41) (see Analysis 9.2), partial nail avulsion with phenol with 1 week's antibiotic afterwards (PNA $+\mathrm{Ph}+\mathrm{AB}$ after) compared with partial nail avulsion with phenol alone (PNA + Ph) (RR 0.90, 95\% CI 0.56 to 1.46) (see Analysis 10.2), or partial nail avulsion with phenol and antibiotics (PNA $+\mathrm{Ph}+\mathrm{AB}$ ) compared to partial nail avulsion with matrix excision (PNA + surg ME) (RR 1.04, 95\% CI 0.64 to 1.70 ) (see Analysis 11.2).

Reyzelman 2000 gave antibiotics before and after the surgical interventions and compared this to giving no antibiotics. When partial nail avulsion with phenol with 1 week's antibiotic afterwards (PNA $+\mathrm{Ph}+\mathrm{AB}$ after) was compared with partial nail avulsion with phenol alone (PNA $+\mathrm{Ph})$, there was no significant difference in postoperative infection (RR $0.18,95 \%$ CI 0.01 to 3.61) (see Analysis 10.2). When partial nail avulsion with phenol with 1 week's antibiotic in advance (PNA $+\mathrm{Ph}+\mathrm{AB}$ advance) was compared with partial nail avulsion with phenol alone $(\mathrm{PNA}+\mathrm{Ph})$, there was no significant difference in postoperative infection (RR $0.20,95 \%$ CI 0.01 to 3.98) (see Analysis 13.1).

\section{3) Pain of operation/postoperative pain}

\section{Surgical procedures}

\section{Chemical ablation and surgery vs surgical procedure}

For the outcome 'pain of operation', there was no significant difference between partial nail avulsion with application of phenol $(\mathrm{PNA}+\mathrm{Ph})$ compared to wedge excision and matricectomy (wedge + surg ME) (RR 0.53, 95\% CI 0.05 to 5.58 - Leahy 1990) (see Analysis 3.2).

When phenol was added to the surgical intervention, there was significantly less postoperative analgesic used in the phenol group in the study by van der Ham 1990 (RR 0.36, 95\% CI 0.25 to 0.54 ) (see Analysis 3.5). However, there was no significant difference in postoperative analgesic use in the 2 groups in the study by Arista 2006 (RR 1.27, 95\% CI 0.69 to 2.37) (see Analysis 3.5).

There was no significant difference in postoperative pain in the study by Gerritsma-Bleeker 2002, when partial nail avulsion and phenol (PNA $+\mathrm{Ph})$ was compared to partial nail avulsion and matrix excision (PNA + surg ME) (MD 0.40, 95\% CI -0.41 to 1.21) (see Analysis 3.6), or in the study by Morkane 1984 when partial nail avulsion and phenol $(\mathrm{PNA}+\mathrm{Ph})$ was compared with wedge excision and matricectomy (wedge + surg ME) (MD -3.86, 95\% CI -14.22 to 6.50) (see Analysis 3.6).

\section{Chemical ablation and partial avulsion vs chemical ablation and surgery}

With regard to the outcome 'postoperative pain', there was no significant difference between chemical ablation with phenol and partial nail avulsion (PNA $+\mathrm{Ph}$ ) and chemical ablation with phenol and wedge resection (wedge $+\mathrm{Ph})(\mathrm{RR} 0.98,95 \% \mathrm{CI} 0.76$ to 1.26) (see Analysis 5.2). It is important to bear in mind that these conclusions are based on the data of one study (Issa 1988). There was also no significant difference in postoperative pain intensity after 24 hours in either group (MD -2.70, 95\% CI -7.55 to 2.15 ) (see Analysis 5.3).

\section{Surgery with electrofulguration vs surgery}

The addition of electrofulguration (to destroy the underlying matrix) to a surgical intervention did not significantly reduce postoperative pain (RR $0.81,95 \%$ CI 0.35 to 1.86 ) (see Analysis 6.1) or postoperative haemorrhage (RR $1.08,95 \%$ CI 0.28 to 4.18 Flores 2006) (see Analysis 6.2).

\section{Pre- and postoperative procedures}

In the study by McIntosh 2006, there was no significant difference in postoperative pain between manuka honey dressing compared 
to paraffin-impregnated tulle gras (MD $0.03,95 \% \mathrm{CI}-0.47$ to 0.53) (see Analysis 7.3).

\section{4) Participant satisfaction}

Non-surgical procedures

\section{Non-surgical interventions with or without pre-or postoperative treatment vs non-surgical interventions with or without postoperative treatment}

One study (Beck 1984) looked at participant satisfaction in a within-patient trial. From after four months of treatment continued until six months after treatment, there was a significant difference in favour of orthonyxia (brace treatment). Participant satisfaction after 6 months follow-up was $60 \%$ after orthonyxia compared to $14 \%$ after conservative treatment (RR 4.20, $95 \%$ CI 1.82 to 9.77). A forest plot could not be provided because of the within-patient comparison.

\section{Non-surgical vs surgical procedures}

When looking at postoperative haemorrhage, no significant differences were seen. However, there is unlikely to be any postoperative haemorrhage with a non-surgical intervention. Kruijff 2008 reported on participant satisfaction, but did not provide a percentage of the treated groups. Instead, the study measured this on a visual analogue scale. Healing time was also reported, but no standard deviations were provided. Therefore, we did not include this data.

\section{Surgical procedures}

\section{Chemical ablation and surgery vs surgical procedure}

There was no significant difference in participant satisfaction in the study by Anderson 1990 when total avulsion with phenol was compared with total avulsion and matrix excision (surg ME) (RR $0.40,95 \%$ CI 0.02 to 9.12 ) (see Analysis 3.7), or in the study by Greig 1991a in which nail edge excision was compared with total avulsion (RR $0.94,95 \%$ CI 0.65 to 1.36 ) (see Analysis 4.2).

\section{DISCUSSION}

\section{Summary of main results}

Twenty-four studies examined the effect of a total of 25 different interventions for ingrowing toenails. Five examined non-surgical interventions, 16 examined surgical interventions, and 4 examined postoperative interventions.

Although there are no results about recurrence for non-surgical intervention with orthonyxia (brace treatment), it does lead to significantly better participant satisfaction than other non-surgical interventions. Surgical interventions were better at preventing recurrence than non-surgical interventions with gutter treatment and probably better than non-surgical treatments with orthonyxia. However, it is likely that there is a decreased risk of postoperative complications when a non-surgical intervention is carried out, due to the less destructive nature of the intervention.

The evidence identified by this systematic review shows that for surgical interventions, more invasive interventions with phenol are likely to reduce recurrence more effectively than less invasive surgical interventions with phenol. In the only study in which a surgical treatment with phenol was compared to the same surgical treatment without phenol, the addition of phenol led to significantly better results.

When looking at postoperative pain, infection, and haemorrhage, no statistically significant differences were found, regardless of the non-surgical interventions performed. We conclude that adding a pre- or postoperative intervention to a non-surgical intervention is not effective when looking at postoperative infection rate, postoperative pain, and healing time. There was a significant reduction in healing time in favour of antibiotics given after a surgical intervention (partial nail avulsion with phenol) when this was compared to antibiotics given before the same surgical intervention. However, because no significant difference in healing time was found when the surgical intervention with antibiotics afterwards was compared with the surgical intervention alone without any antibiotics, this effect was judged as not clinically relevant (Reyzelman 2000).

\section{Overall completeness and applicability of evidence}

The previous review included nine studies. In our review we included 24 studies, of which 7 were also included in the previous review (Anderson 1990; Greig 1991a; Issa 1988; Leahy 1990; Morkane 1984; van der Ham 1990; Varma 1983). The two studies that were part of the previous review, but which we did not include, were quasi-randomised (Andrew 1979; Tait 1987). We found seven studies that were published after the date of the last search (October 2002) for the previous review. Although we found nine new studies about surgical interventions, the overall conclusions for the effectiveness of surgical interventions did not change. We found many studies comparing surgical interventions, but we only found a few studies about non-surgical interventions (Kim 2003; Kruijff 2008; Perry 1984; Wallace 1979b). This is remarkable, given the fact that non-surgical interventions are thought to be effective in stage I, and some cases of stage II, ingrown toenails. 
For severe stage II and stage III ingrowing toenails, surgical interventions are likely to be more effective than non-surgical interventions. However, the studies comparing non-surgical interventions with surgical interventions did not mention if they distinguished between different stages of the ingrowing toenail. One can argue that a stage III ingrown toenail will not benefit from a non-surgical intervention, e.g. orthonyxia, but a stage I ingrown toenail will. In this review, the place of non-surgical interventions in the treatment of ingrowing toenails is unclear. There is a lack of evidence proving the value of non-surgical interventions; therefore, no hard conclusions can be made about the effect of non-surgical interventions compared to surgical interventions. Because the studies made no distinction between different stages of presentation of ingrowing toenails, it is not possible to make recommendations at this stage with regard to whether more radical surgical treatments are needed for more severe disease.

In this review, no conclusions can be made for short-term outcome measures, such as relief of symptoms, participant satisfaction, and postoperative pain. The included studies used different outcome measures, which makes comparison difficult. Because it is not possible to make a distinction between the pain/impact caused by an intervention and the pain/impact of the ingrowing toenail itself, outcome measures that measure both aspects are needed. The use of uniform, short-term outcome measures, such as healing time as an objective measurement and participant satisfaction as a subjective measurement, are needed to give information about which interventions give adequate relief of symptoms.

\section{Quality of the evidence}

The included studies had a median number of 118 participants, divided into 2, 3, or even 4 treatment arms. The largest study (Sykes 1988c) had 424 participants divided into 3 treatment arms. However, due to unsatisfying results in one arm, they decided to close this arm, which resulted in a high number of participants in the other arms. The loss to follow up varied between studies, with the smallest being 1\% (Issa 1988) and the largest being 42\% (Gem 1990b).

For only a small proportion of items in the 'Risk of bias' table, a high risk of bias could be assigned (Figure 5). This is largely due to the fact that most studies did not report details on several methodological issues and the follow-up period. Blinding the participant for a non-surgical intervention is difficult; only one study (McIntosh 2006) blinded the participant. It is not possible to blind a participant for orthonyxia or gutter treatment, both of which have to be worn for several days/weeks. We don't make a comparison here with surgical interventions.

\section{Potential biases in the review process}

Due to our thorough searching efforts, we do not expect that we missed relevant randomised controlled trials. There are two ongoing studies (ISRCTN32883274; NCT00641433), and four studies are awaiting classification (Altinyazar 2010; Peyvandi 2011; Tatlican 2009; Zaba 2002).

\section{Agreements and disagreements with other studies or reviews}

In the previous review (Rounding 2003), the authors decided to divide recurrence into symptomatic and asymptomatic recurrence. In this review, we decided not to divide recurrence in this way, but to use regrowth and recurrence as primary outcomes. We defined 'regrowth' as growth of the nail after surgical intervention, but without symptoms; and 'recurrence' as being new penetration of the nailfold by the nail, causing symptoms (after an intervention). However, regrowth is not an appropriate outcome measure for non-surgical interventions. For example, when comparing a nonsurgical intervention with a surgical intervention, there is no regrowth because with a non-surgical intervention the troublesome part of the nail is not removed. Recurrence is a suitable outcome for non-surgical interventions, but not for postoperative interventions, given the fact that these interventions aim to reduce postoperative complications and that they (probably) do not have an impact on the risk of recurrence.

In the former version of the review, it was concluded that phenollisation combined with a simple avulsion was more effective than the use of more invasive excisional surgical procedures to prevent symptomatic recurrence at six months or more. This is not found in this review because the surgical procedures in the comparison were not comparable. Because the surgical procedures were not comparable, the other conclusion of the former version of this review cannot be confirmed, which is that the addition of phenol, when performing a total or partial nail avulsion, dramatically reduces the rate of symptomatic recurrence.

\section{AUTHORS' CONCLUSIONS}

\section{Implications for practice}

Surgical interventions are more effective than non-surgical interventions with gutter treatment in preventing recurrence of the ingrowing toenail.

In the studies comparing a surgical intervention to a surgical intervention with application of phenol, the addition of phenol is probably more effective in preventing recurrence and regrowth. Because there is only one study in which surgical interventions in both study arms were equal and where the addition of phenol leads to better results, more studies have to be done to confirm these outcomes. A more invasive surgical intervention with application 
of phenol is likely to reduce the risk of recurrence more effectively than a less invasive surgical intervention with the application of phenol.

Postoperative interventions do not decrease the risk of postoperative infection or postoperative pain, or give a shorter healing time. This means that there is no evidence to give antibiotics to prevent postoperative infections.

\section{Implications for research}

New trials are needed to determine the place of non-surgical interventions in the treatment of stage I and II ingrowing toenails.

New trials are needed to determine if the addition of chemical ablation to a surgical procedure gives a reduction of the risk of recurrence compared to the surgical procedure alone.

New trials should also examine relevant, uniform short-term outcomes, such as healing time as an objective measurement and participant satisfaction as a subjective measurement, as well as the primary outcome of recurrence or regrowth.

\section{ACKNOWLEDGEMENTS}

We are grateful to the following people:

- Jan W. Schoones, of the Walaeus Library of the Leiden University Medical Center, Leiden, for his help in searching different databases for relevant articles;

- Wouter de Ruijter, Leiden University Medical Center, Leiden; and Urbà González, Barcelona, for their help in translating and assessing two Spanish papers;

- the late Johan van der Wouden, Alblasserdam, for his help in translating and assessing a Danish paper;

- Karsten Juhl Jørgensen, Copenhagen, for his help in translating and assessing a Danish paper; and

- Jytte Beck and W. Arthur Tanner for providing details of the design of their studies (Beck 1984; Issa 1988).

The Cochrane Skin Group editorial base would like to thank Robert Dellavalle, Jo Leonardi-Bee, and Philippa Middleton, who were the Key, Statistics, and Methodology Editors, respectively; and Joel Heidelbaugh and Geoffrey Woodruff who were clinical and consumer referees, respectively, on this review.

\section{REFERENCES}

\section{References to studies included in this review}

\section{Anderson 1990 \{published data only\}}

Anderson JH, Greig JD, Ireland AJ, Anderson JR. Randomized, prospective study of nail bed ablation for recurrent ingrowing toenails. Journal of the Royal College of Surgeons of Edinburgh 1990;35:240-2.

Arista 2006 \{published data only\}

Arista GF, Merino JE. Onychocryptosis: study comparing postoperative period after partial lateral matricectomy vs partial lateral matricectomy with phenolization [Onicocriptosis: estudio comparativo del periodo posoperatorio de una matricectomía parcial lateral con el de una matricectomía parcial lateral con fenolizacíon]. Dermatología Revista Mexicana 2006;50(3):87-93.

\section{Beck $1984\{$ \{published data only\}}

Beck J, Nielsen J. Orthonyxia compared with conservative treatment in ingrowing toenail of the great toe [Ortonyksi kontra konservativ behandling ved unguis incarnatus hallucis]. Ugeskrift for Laeger 1984;146(46):3537-8.

Bos 2006 \{published data only\}

Bos AMC, van Tilburg MWA, van Sorge AA, Klinkenbijl JHG. Randomized clinical trial of surgical technique and local antibiotics for ingrowing toenail. British Journal of Surgery 2006;94:292-6.
Dovison 2001 \{published data only\}

Dovison R, Keenan AM. Wound healing and infection in nail matrix phenolisation wounds. Does topical medication make a difference?. Journal of the American Podiatric Medical Association 2001;91(5):230-3.

Flores 2006 \{published data only\}

Flores AV, Merino JE. Partial matricectomy vs partial matricectomy with electrofulguration as a treatment for onychocryptosis [Matricectomía parcial quirúrgica vs matricectomía parcial con electrofulguración en el tratamiento de la onicocriptosis]. Dermatología Revista Mexicana 2006;50(2):54-9.

Gem 1990a \{published data only\} Gem MA, Sykes PA. Ingrowing toenails: studies of segmental chemical ablation (study 1). British Journal of Clinical Practice 1990;44:562-3.

Gem 1990b \{published data only\} Gem MA, Sykes PA. Ingrowing toenails: studies of segmental chemical ablation (study 2). British Journal of Clinical Practice 1990;44:562-3.

Gerritsma-Bleeker 2002 \{published data only\} Gerritsma-Bleeker CLE, Klaase JM, Geelkerken LH, Hermans J, van Det RJ. Partial matrix excision or segmental phenolization for ingrowing toenails. Archives of Surgery 2002;137:320-5. 
Greig 1991a \{published data only\}

Grieg JD, Anderson JH, Ireland AJ, Anderson JR. The surgical treatment of ingrowing toenails (Study 1). Journal of Bone and Joint Surgery. British Volume 1991;73:131-3.

Issa 1988 \{published data only\}

Issa MM, Tanner WA. Approach to ingrowing toenails: the wedge resection/segmental phenolization combination treatment. British Journal of Surgery 1988;75:181-3.

Kim 2003 \{published data only\} Kim YJ, Ko JH, Choi KC, Lee CG, Lim KJ. Nail-splinting technique for ingrown toenails: The therapeutic effects and the proper removal time of the splint. Dermatologic Surgery 2003;29:745-8.

Kruijff 2008 \{published data only\}

Kruijff S, van Det RJ, van der Meer GT, van den Berg ICMAE, van der Palen J, Geelkerken RH. Partial matrix excision or orthonyxia for ingrowing toenails. Journal of American College of Surgeons 2008;206:148-153.

Leahy 1990 \{published data only\}

Leahy AL, Timon CI, Craig A, Stephens RB. Ingrowing toenails: improving treatment. Surgery 1990;107:566-7.

McIntosh 2006 \{published data only\}

McIntosh CD, Thomson CE. Honey dressing versus paraffin tulle gras dressing following toenail surgery. Journal of Wound Care 2006;15(3):133-6.

Morkane 1984 \{published data only\}

Morkane AJ, Robertson RW, Inglis GS. Segmental phenolization of ingrowing toenails: a randomized controlled study. British Journal of Surgery 1984;71:526-7.

Perry 1984 \{published data only\}

Perry EP, O’Malley S, McGowan B, Cullimore G, Watkin DFL. A comparison of four nail-conserving procedures for ingrowing toenail. British Journal of Surgery 1984;71(11): 912.

Reyzelman 2000 \{published data only\}

Reyzelman AM, Trombello KA, Vayser DJ, Armstrong DG, Harkless LB. Are antibiotics necessary in the treatment of locally infected ingrowing toenails?. Archives of Family Medicine 2000;9:930-2.

Shaath 2005 \{published data only\} Shaath N, Shea J, Whiteman I, Zarugh A. A prospective randomized comparison of the Zadik procedure and chemical ablation in the treatment of ingrown toenails. Foot \& Ankle International 2005;26(5):401-5.

Sykes 1988b \{published data only\}

Sykes PA, Kerr R. Treatment of ingrowing toenails by surgeons and chiropodists (study 2). Chiropodist 1988;43: 224.

Sykes 1988c \{published data only\}

Sykes PA, Kerr R. Treatment of ingrowing toenails by surgeons and chiropodists (study 3). Chiropodist 1988;43: 224 .

van der Ham 1990 \{published data only\} van der Ham AC, Hackeng CA, Yo TI. The treatment of ingrowing toenails. A randomised comparison of wedge excision and phenol cauterisation. Journal of Bone and Joint Surgery. British Volume 1990;72:507-9.

Varma 1983 \{published data only\}

Varma JS, Kinninmonth AW, Hamer Hodges DW. Surgical wedge excision versus phenol wedge cauterisation for ingrowing toenail. A controlled study. Journal of the Royal College of Surgeons of Edinburgh 1983;28:331-2.

Wallace 1979b \{published data only\}

Wallace WA, Milne DD, Andrew T. Gutter treatment for ingrowing toenails (study 2). British Medical Journal 1979; 2(6183): 168-71.

\section{References to studies excluded from this review}

Aksahal 2001 \{published data only\}

Aksahal AB, Atahan C, Öztas P, Oruk ș. Minimizing postoperative drainage with $20 \%$ ferric chloride after chemical matricectomy with phenol. Dermatologic Surgery 2001;27:158-160.

Andrew 1979 \{published data only\}

Andrew T, Wallace WA. Nail bed ablation - excise or cauterise? A controlled study. British Medical Journal 1979; 1(6177): 1539 .

Arai 2004 \{published data only\}

Arai H, Arai T, Nakajima H, Haneke E. Formable acrylic treatment for ingrowing nail with gutter splint and sculptured nail. International Journal of Dermatology 2004; 43:759-765.

Boberg 2002 \{published data only\} Boberg JS, Frederiksen MS, Harton FM. Scientific analysis of phenol nail surgery. Journal of the Amrican Podiatric Medical Association 2002;92(10):575-9.

Bossers 1992 \{published data only\} Bossers AM, Jansen IMC, Eggink WF. Rational therapy for ingrown toenails. A prospective study. Acta Orthopaedica Belgica 1992;58(3):325-9.

Bostanci 2007 \{published data only\} Bostanci S, Kocyigit P, Gürgey E. Comparison of phenol and sodium hydroxide chemical matricectomies for the treatment of ingrowing toenails. Dermatologic Surgery 2007; 33:680-5.

Burssens 1987 \{published data only\}

Burssens P, Vereecken L, van Loon C. A randomized controlled study of two treaments for ingrowing toenails [Een vergelijkende studie tussen twee behandelingswijzen voor onychocryptosis (ingegroeide teennagel)]. Acta Chirurgica Belgica 1987;87:294-7.

Cameron 1981 \{published data only\} Cameron PF. Ingrowing toenails: an evaluation of two treatments. British Medical Journal 1981;283:821-822.

Córdoba-Fernandez 2008 \{published data only\} Córdoba-Fernandez A, Rayo-Rosado R, Juarez-Jiménez JM. Platelet gel for the surgical treatment of onychocryptosis. Journal of the American Podiatric Medical Association 2008; 98(4):296-301. 
Foley 1994 \{published data only\}

Foley GB, Allen J. Wound healing after toenail avulsion. A comparison of Kaltostat and Melolin as postoperative dressings. The Foot 1994;4:88-91.

Greig 1991b \{published data only\}

Greig JD, Anderson JH, Ireland AJ, Anderson JR. The surgical treatment of ingrowing toenails [Study 2]. Journal of Bone and Joint Surgery 1991;73-B:131-3.

Herold 2001 \{published data only\}

Herold N, Houshian S, Riegels-Nielsen P. A prospective comparison of wegde matrix resection with nail matrix phenolization for the treatment of ingrown toenail. The Journal of Foot \& Ankle Surgery 2001;40(6):390-5.

Holt 1987 \{published data only\}

Holt SDH, Tiwari IB, Howell GP. Phenolisation as an adjunct to Zadik's procedure for ingrowing toenail and onychogryphosis. Journal of the Royal College of Surgeons of Edinburgh 1987;32(4):228-229.

Kocyigit 2005 \{published data only\}

Kocyigit P, Bostanci S, Özdemir E, Gürgey E. Sodium hydroxide chemical matricectomy for the treatment of ingrown toenails: Comparison of three different application periods. Dermatologic Surgery 2005;31:744-7.

Schütte 1980 \{published data only\}

Schütte PR. Partial excision of matrix as a treatment of the ingrowing nail [Partiële matrixexcisie als behandeling van de ingroeiende nagel]. Nederlands Tijdschrift voor Geneeskunde 1980;124(44):1868-1870.

Sykes 1988a \{published data only\}

Sykes PA, Kerr R. Treatment of ingrowing toenails by surgeons and chiropodists. Chiropodist 1988;43:224.

Tada 2004 \{published data only\}

Tada H, Hatoko M, Tanaka A, Iioka H, Niitsuma K, Mashiba K. Clinical comparison of the scanning CO

2 laser and conventional surgery in the treatment of ingrown nail deformities. Journal of Dermatological Treatment 2004; 15:387-390.

\section{Tait 1987 \{published data only\}}

Tait GR, Tuck JS. Surgical or phenol ablation of the nail bed for ingrowing toenails: a randomised controlled trial. Journal of the Royal College of Surgeons of Edinburgh 1987; 32:358-60.

\section{References to studies awaiting assessment}

Altinyazar 2010 \{published data only\}

Altinyazar HC, Demirel CB, Koca R, Hosnuter M. Digital block with and without epinephrine during chemical matricectomy with phenol. Dermatologic Surgery 2010;36 (10):1568-1571.

Peyvandi 2011 \{published data only\}

Peyvandi H, Robati RM, Yegane RA, Hajinasrollah E, Toossi P, Peyvandi AA, et al.Comparison of two surgical methods (Winograd and sleeve method) in the treatment of ingrown toenail. Dermatologic Surgery 2011;37(3):

331-335.

Tatlican 2009 \{published data only\}

Tatlican S, Yamangöktürk B, Eren C, Eskio

ğ lu F, Adiyaman S. Comparison of phenol applications of different durations for the cauterization of the germinal matrix: an efficacy and safety study. Acta Orthopaedica et Traumatologica Turcica 2009;43(4):298-302.

Zaba 2002 \{published data only\} Zaba R, Zaba Z, Krol J, Karon J. Laser treatment of ingrown toenails. Annales de Dermatologie et de Venereologie 2002; 129:525.

\section{References to ongoing studies}

\section{ISRCTN32883274 \{unpublished data only\}}

ISRCTN32883274. Radio surgery versus $80 \%$ phenol for toe nail matrix ablation: a randomised comparison study. http://www.controlled-trials.com/ISRCTN32883274 (accessed 11 December 2011).

NCT00641433 \{unpublished data only\} NCT00641433. Topical collagen-silver versus standard care following phenol ablation of ingrown nails: a randomized controlled trial. http://clinicaltrials.gov/ct2/ show/NCT00641433 (accessed 11 December 2011).

\section{Additional references}

\section{Antrum 1984}

Antrum RM. Radical excision of the nailfold for ingrowing toenail. The Journal of Bone and Joint Surgery 1984;66(1): $63-5$.

Cox 1995

Cox HA, Jones MRO. Direct extension osteomyelitis secondary to chronic onychocryptosis. Three case reports. Journal of the American Podiatric Medical Association 1995; 85(6):321-4.

DeLauro 2004

DeLauro NM, DeLauro TM. Onychocryptosis. Clinics in Podiatric Medicine and Surgery 2004;21(4):617-30.

\section{Dunn 2004}

Dunn JE, Link CL, Felson DT, Crincoli MG, Keysor JJ, McKinlay JB. Prevalence of foot and ankle conditions in a multiethnic community sample of older adults. American Journal of Epidemiology 2004;159(5):491-8.

El-Shaer 2007

El-Shaer WM. Lateral fold rotational flap technique for treatment if ingrown nail. Plastic Reconstructive Surgery 2007;120(7):2131-33.

Gunal 2003

Gunal I, Kosay C, Veziroglu A, Balkan Y, Ilhan F. Relationship between onychocryptosis and foot type and treatment with toe spacer. A preliminary investigation. Journal of the American Podiatric Medical Association 2003; 93(1):33-6. 


\section{Heidelbaugh 2009}

Heidelbaugh JJ, Lee H. Management of the ingrown toenail. American Family Physician 2009;79(4):303-8.

\section{Higgins 2008}

Higgins JPT, Green S (editors). Cochrane Handbook for Systematic Reviews of Interventions. Version 5.0.1 [updated September 2008]. The Cochrane Collaboration. Available on www.cochrane-handbook.org, 2008.

\section{Larsen 1971}

Larsen K. Orthonycsia. Regulation of nails [Ortonyksi. Negleregulering]. Ugeskr Laeg 1971;133(38):1867-8.

\section{Ross 1969}

Ross WR. Treatment of the ingrown toenail and a new anesthetic method. Surgical Clinics of North America 1969; 49(6):1499-1504.

Schulte 1998

Schulte KW, Neumann NJ, Ruzicka T. Surgical Pearl: Nail splinting by flexible tube--A new noninvasive treatment for ingrown toenails. Journal of the American Academy of Dermatology 1998;39:629-630.

\section{Westert 2005}

Westert GP, Schellevis FG, de Bakker DH, Groenewegen PP, Bensing JM, Vander ZJ. Monitoring health inequalities through general practice: the Second Dutch National Survey of General Practice. European Journal of Public Health 2005;15:59-65.

\section{Winograd 1929}

Winograd AM. A modification in the technic of operation for ingrown toenail. Journal of the American Medical Association 1929;92(3):229-230.

\section{Yang 2008}

Yang G, Yanchar NL, Lo AYS, Jones SA. Treatment of ingrown toenails in the pediatric population. Journal of Pediatric Surgery 2008;43:931-5.

\section{Zadik 1950}

Zadik FR. Obliteration of the nail bed of the great toe without shortening the terminal phalanx. The Journal of Bone and Joint Surgery 1950;32(1):66-7.

\section{References to other published versions of this review}

\section{Rounding 2003}

Rounding C, Bloomfield S. Surgical treatments for ingrowing toenails. Cochrane Database of Systematic Reviews 2003, Issue 1. [DOI: 10.1002/14651858.CD001541.pub2]

* Indicates the major publication for the study 
CHARACTERISTICS OF STUDIES

Characteristics of included studies [ordered by study ID]

Anderson 1990

\begin{tabular}{|c|c|c|}
\hline Methods & \multicolumn{2}{|c|}{ This was a randomised controlled trial (UK). } \\
\hline Participants & \multicolumn{2}{|c|}{$\begin{array}{l}\text { - } 31 \text { participants (age range }=15 \text { to } 73 \text { years) attending the general surgery } \\
\text { departments of hospitals, who had undergone at least } 2 \text { previous surgical procedures } \\
\text { Onychogryphosis was excluded. }\end{array}$} \\
\hline Interventions & \multicolumn{2}{|c|}{$\begin{array}{l}\text { A: zadik (17) } \\
\text { B: phenol and Zadik (14) }\end{array}$} \\
\hline Outcomes & \multicolumn{2}{|c|}{$\begin{array}{l}\text { Outcomes of the trial } \\
\text { 1) Symptomatic recurrence } \\
\text { 2) Total recurrence after } 12 \text { months } \\
\text { 3) Postoperative infection after } 1 \text { month } \\
\text { 4) Participant satisfaction }\end{array}$} \\
\hline Notes & \multicolumn{2}{|l|}{-} \\
\hline \multicolumn{3}{|l|}{ Risk of bias } \\
\hline Bias & Authors' judgement & Support for judgement \\
\hline $\begin{array}{l}\text { Random sequence generation (selection } \\
\text { bias) }\end{array}$ & Unclear risk & No details were given. \\
\hline Allocation concealment (selection bias) & Unclear risk & This was unclear. \\
\hline Selective reporting (reporting bias) & Unclear risk & This was unclear. \\
\hline Other bias & Low risk & $\begin{array}{l}\text { There was an imbalance for sex and age, } \\
\text { without risk of bias }\end{array}$ \\
\hline Inclusion and exclusion criteria? & Low risk & $\begin{array}{l}\text { Quote: "The study included..." } \\
\text { Quote: "All patients had recurrent..." } \\
\text { Quote: "Onychogryphotic nails were ex- } \\
\text { cluded." }\end{array}$ \\
\hline $\begin{array}{l}\text { Outcome assessor blinded? } \\
\text { All outcomes }\end{array}$ & Low risk & $\begin{array}{l}\text { After } 2 \text { weeks the assessor was not blinded, } \\
\text { but after } 1 \text { year the assessor was blinded }\end{array}$ \\
\hline $\begin{array}{l}\text { Participant blinded? } \\
\text { All outcomes }\end{array}$ & High risk & This was not reported. \\
\hline $\begin{array}{l}\text { Intention-to-treat? } \\
\text { All outcomes }\end{array}$ & Low risk & $\begin{array}{l}\text { All included participants were included in } \\
\text { the final analysis }\end{array}$ \\
\hline
\end{tabular}


Anderson 1990 (Continued)

Withdrawals or dropouts?

All outcomes

Arista 2006

Methods

This was a randomised controlled trial (Mexico).

Participants

- 33 participants with 37 ingrown toenails were randomly selected $(\mathrm{M} / \mathrm{F}=17 / 16)$.

Their age was not reported.

Interventions

A: partial lateral matricectomy and phenol cauterization (17)

B: partial lateral matricectomy only (16)

Outcomes

\section{Outcomes of the trial}

1) Postoperative pain

2) Time to heal

Notes

\section{Risk of bias}

\begin{tabular}{|c|c|c|}
\hline Bias & Authors' judgement & Support for judgement \\
\hline $\begin{array}{l}\text { Random sequence generation (selection } \\
\text { bias) }\end{array}$ & Unclear risk & No details were given. \\
\hline Allocation concealment (selection bias) & Unclear risk & No details were given. \\
\hline Selective reporting (reporting bias) & Unclear risk & This was unclear. \\
\hline Other bias & Unclear risk & This was unclear. \\
\hline Inclusion and exclusion criteria? & Low risk & $\begin{array}{l}\text { Quote: “...included onychocryptosis stage } \\
\text { III...” } \\
\text { Quote: “...excluded...” }\end{array}$ \\
\hline $\begin{array}{l}\text { Outcome assessor blinded? } \\
\text { All outcomes }\end{array}$ & High risk & This was not reported. \\
\hline $\begin{array}{l}\text { Participant blinded? } \\
\text { All outcomes }\end{array}$ & High risk & This was not reported. \\
\hline $\begin{array}{l}\text { Intention-to-treat? } \\
\text { All outcomes }\end{array}$ & Low risk & $\begin{array}{l}\text { All included participants were included in } \\
\text { the final analysis }\end{array}$ \\
\hline $\begin{array}{l}\text { Withdrawals or dropouts? } \\
\text { All outcomes }\end{array}$ & Low risk & There were no withdrawals or dropouts \\
\hline
\end{tabular}


Beck 1984

\begin{tabular}{|c|c|c|}
\hline Methods & \multicolumn{2}{|c|}{ This was a randomised controlled trial (Denmark). } \\
\hline Participants & \multicolumn{2}{|c|}{ - Participants (36) with bilateral unguis incarnatus } \\
\hline Interventions & \multicolumn{2}{|c|}{$\begin{array}{l}\text { A: conservative treatment }(35) \\
\text { B: orthonyxia (brace treatment) (35) }\end{array}$} \\
\hline Outcomes & \multicolumn{2}{|c|}{$\begin{array}{l}\text { Outcomes of the trial } \\
\text { 1) Participant satisfaction }\end{array}$} \\
\hline Notes & \multicolumn{2}{|c|}{$\begin{array}{l}\text { In this 'within patient' trial, } 36 \text { patients with bilateral ingrowing toenails participated. } \\
\text { Every pair of toes was randomised: } 1 \text { toe was treated conservatively; the other with a } \\
\text { brace }\end{array}$} \\
\hline \multicolumn{3}{|l|}{ Risk of bias } \\
\hline Bias & Authors' judgement & Support for judgement \\
\hline $\begin{array}{l}\text { Random sequence generation (selection } \\
\text { bias) }\end{array}$ & Unclear risk & This was not reported. \\
\hline Allocation concealment (selection bias) & Low risk & $\begin{array}{l}\text { Third party randomisation was undertaken } \\
\text { using prearranged closed envelopes }\end{array}$ \\
\hline Selective reporting (reporting bias) & Unclear risk & This was not reported. \\
\hline Other bias & Unclear risk & This was not reported. \\
\hline Inclusion and exclusion criteria? & Low risk & $\begin{array}{l}\text { Quote: “...inclusion bilateral unguis incar- } \\
\text { natus...” } \\
\text { Quote: "Exclusion: impaired...” }\end{array}$ \\
\hline $\begin{array}{l}\text { Outcome assessor blinded? } \\
\text { All outcomes }\end{array}$ & High risk & This was not reported. \\
\hline $\begin{array}{l}\text { Participant blinded? } \\
\text { All outcomes }\end{array}$ & High risk & This was not reported. \\
\hline $\begin{array}{l}\text { Intention-to-treat? } \\
\text { All outcomes }\end{array}$ & High risk & $\begin{array}{l}\text { Dropouts were not included in the final } \\
\text { analysis. }\end{array}$ \\
\hline $\begin{array}{l}\text { Withdrawals or dropouts? } \\
\text { All outcomes }\end{array}$ & Low risk & $\begin{array}{l}4 / 36 \text { participants were not included in the } \\
\text { final analysis, due to different reasons }\end{array}$ \\
\hline
\end{tabular}


Bos 2006

\begin{tabular}{l|l}
\hline Methods & $\begin{array}{l}\text { This was a randomised controlled trial (Netherlands, Departments of Surgery/Pharma- } \\
\text { cology) }\end{array}$ \\
\hline Participants & $\begin{array}{l}\text { - } 123 \text { participants (age range }=9 \text { to } 73 \text { years, M/F }=72 / 45) \text { with ingrowing toenail. } \\
\text { All participants had partial nail avulsion (PNA). }\end{array}$ \\
\hline Interventions & $\begin{array}{l}\text { A: partial nail avulsion (PNA) with excision of the matrix (38) } \\
\text { B: PNA with excision of the matrix and application of antibiotics (22) } \\
\text { C: PNA with application of phenol (37) } \\
\text { D: PNA with application of phenol and application of antibiotics (26) }\end{array}$ \\
\hline
\end{tabular}

\begin{tabular}{|c|c|}
\hline Outcomes & $\begin{array}{l}\text { Outcomes of the trial } \\
\text { 1) Recurrence after } 12 \text { months } \\
\text { 2) Infection after } 1 \text { week } \\
\text { 3) Regrowth/spike formation }\end{array}$ \\
\hline Notes & - \\
\hline
\end{tabular}

\section{Risk of bias}

\begin{tabular}{|c|c|c|}
\hline Bias & Authors' judgement & Support for judgement \\
\hline $\begin{array}{l}\text { Random sequence generation (selection } \\
\text { bias) }\end{array}$ & Unclear risk & No details were given. \\
\hline Allocation concealment (selection bias) & Unclear risk & $\begin{array}{l}\text { Third party independent randomisation } \\
\text { was not mentioned. }\end{array}$ \\
\hline Selective reporting (reporting bias) & Unclear risk & This was unclear. \\
\hline Other bias & Unclear risk & No baseline characteristics were given. \\
\hline Inclusion and exclusion criteria? & Low risk & $\begin{array}{l}\text { Quote: "Patients included had..." } \\
\text { Quote: "Exclusion criteria were..." }\end{array}$ \\
\hline $\begin{array}{l}\text { Outcome assessor blinded? } \\
\text { All outcomes }\end{array}$ & Low risk & $\begin{array}{l}\text { Quote: "All outcomes were assessed by in- } \\
\text { dependent observers who were blinded for } \\
\text { initial treatment." }\end{array}$ \\
\hline $\begin{array}{l}\text { Participant blinded? } \\
\text { All outcomes }\end{array}$ & High risk & This was not reported. \\
\hline $\begin{array}{l}\text { Intention-to-treat? } \\
\text { All outcomes }\end{array}$ & High risk & $\begin{array}{l}\text { Not all of the participants were analysed at } \\
\text { the end of the study }\end{array}$ \\
\hline $\begin{array}{l}\text { Withdrawals or dropouts? } \\
\text { All outcomes }\end{array}$ & Low risk & $6 / 123$ participants were lost to follow up. \\
\hline
\end{tabular}


Dovison 2001

\begin{tabular}{|c|c|c|}
\hline Methods & \multicolumn{2}{|c|}{ This was a randomised controlled trial (Australia, Faculty of Public Health Medicine) } \\
\hline Participants & \multicolumn{2}{|c|}{$\begin{array}{l}\text { - } 42 \text { Participants were included }(\mathrm{M} / \mathrm{F}=20 / 22) \text {. Age was reported for each } \\
\text { treatment group separately. }\end{array}$} \\
\hline Interventions & \multicolumn{2}{|c|}{$\begin{array}{l}\text { A: paraffin gauze }(13) \\
\text { B: povidone-iodine } 10 \% \text { and paraffin gauze }(13) \\
\text { C: amorphous hydrogel and paraffin gauze (16) }\end{array}$} \\
\hline Outcomes & \multicolumn{2}{|c|}{$\begin{array}{l}\text { Outcomes of the trial } \\
\text { 1) Postoperative symptoms } \\
\text { 2) Healing time }\end{array}$} \\
\hline Notes & \multicolumn{2}{|l|}{-} \\
\hline \multicolumn{3}{|l|}{ Risk of bias } \\
\hline Bias & Authors' judgement & Support for judgement \\
\hline $\begin{array}{l}\text { Random sequence generation (selection } \\
\text { bias) }\end{array}$ & Unclear risk & No details were given. \\
\hline Allocation concealment (selection bias) & Unclear risk & No details were given. \\
\hline Selective reporting (reporting bias) & Unclear risk & This was unclear. \\
\hline Other bias & Unclear risk & This was unclear. \\
\hline Inclusion and exclusion criteria? & Low risk & $\begin{array}{l}\text { Quote: "Participants were selected...and } \\
\text { Table } 1 \text { gives a list of the exclusion criteria. } \\
\text { ” }\end{array}$ \\
\hline $\begin{array}{l}\text { Outcome assessor blinded? } \\
\text { All outcomes }\end{array}$ & Unclear risk & No details were given. \\
\hline $\begin{array}{l}\text { Participant blinded? } \\
\text { All outcomes }\end{array}$ & High risk & This was not reported. \\
\hline $\begin{array}{l}\text { Intention-to-treat? } \\
\text { All outcomes }\end{array}$ & High risk & $\begin{array}{l}6 / 42 \text { participants were not included in the } \\
\text { final analysis. }\end{array}$ \\
\hline $\begin{array}{l}\text { Withdrawals or dropouts? } \\
\text { All outcomes }\end{array}$ & High risk & $\begin{array}{l}6 / 42 \text { participants were excluded, but no } \\
\text { reason why was given }\end{array}$ \\
\hline
\end{tabular}


Flores 2006

\begin{tabular}{|c|c|c|}
\hline Methods & \multicolumn{2}{|c|}{ This was a randomised controlled trial (Mexico). } \\
\hline Participants & \multicolumn{2}{|c|}{ - 33 participants with onychocryptosis were randomly allocated. } \\
\hline Interventions & \multicolumn{2}{|c|}{$\begin{array}{l}\text { A: surgical partial matricectomy (17) } \\
\text { B: partial matricectomy with electrofulguration (21) }\end{array}$} \\
\hline Outcomes & \multicolumn{2}{|c|}{$\begin{array}{l}\text { Outcomes of the trial } \\
\text { 1) Postoperative pain intensity } \\
\text { 2) Postoperative oedema, secretion, and bleeding } \\
\text { 3) Healing time }\end{array}$} \\
\hline Notes & \multicolumn{2}{|l|}{-} \\
\hline \multicolumn{3}{|l|}{ Risk of bias } \\
\hline Bias & Authors' judgement & Support for judgement \\
\hline $\begin{array}{l}\text { Random sequence generation (selection } \\
\text { bias) }\end{array}$ & Unclear risk & No details were given. \\
\hline Allocation concealment (selection bias) & Unclear risk & No details were given. \\
\hline Selective reporting (reporting bias) & Unclear risk & This was unclear. \\
\hline Other bias & Unclear risk & This was unclear. \\
\hline Inclusion and exclusion criteria? & Low risk & $\begin{array}{l}\text { Quote: “...included when stage II and/or } \\
\text { III...” and “...excluded when stage I or vas- } \\
\text { cular insufficiency...” }\end{array}$ \\
\hline $\begin{array}{l}\text { Outcome assessor blinded? } \\
\text { All outcomes }\end{array}$ & Unclear risk & No details were given. \\
\hline $\begin{array}{l}\text { Participant blinded? } \\
\text { All outcomes }\end{array}$ & High risk & This was not reported. \\
\hline $\begin{array}{l}\text { Intention-to-treat? } \\
\text { All outcomes }\end{array}$ & Low risk & $\begin{array}{l}\text { All included participants were included in } \\
\text { the final analysis }\end{array}$ \\
\hline $\begin{array}{l}\text { Withdrawals or dropouts? } \\
\text { All outcomes }\end{array}$ & Low risk & There were no dropouts. \\
\hline
\end{tabular}


Gem 1990a

\begin{tabular}{|c|c|c|}
\hline Methods & \multicolumn{2}{|c|}{ This was a randomised prospective study (UK). } \\
\hline Participants & \multicolumn{2}{|c|}{ - 219 participants were randomly allocated. } \\
\hline Interventions & \multicolumn{2}{|c|}{$\begin{array}{l}\text { A: chemical ablation with a } 3 \text {-minute application of } 80 \% \text { phenol (109) } \\
\text { B: chemical ablation with a } 2 \text {-minute application of } 10 \% \text { sodium hydroxide (110) }\end{array}$} \\
\hline Outcomes & \multicolumn{2}{|c|}{$\begin{array}{l}\text { Outcomes of the trial } \\
\text { 1) Recurrence } \\
\text { 2) Time to become pain free } \\
\text { 3) Healing time }\end{array}$} \\
\hline Notes & \multicolumn{2}{|c|}{ There was a large loss to follow up: $28 \%$. } \\
\hline \multicolumn{3}{|l|}{ Risk of bias } \\
\hline Bias & Authors' judgement & Support for judgement \\
\hline $\begin{array}{l}\text { Random sequence generation (selection } \\
\text { bias) }\end{array}$ & Unclear risk & No details were given. \\
\hline Allocation concealment (selection bias) & Unclear risk & No details were given. \\
\hline Selective reporting (reporting bias) & Unclear risk & This was unclear. \\
\hline Other bias & Unclear risk & This was unclear. \\
\hline Inclusion and exclusion criteria? & Low risk & $\begin{array}{l}\text { Quote: "Patients were accepted...symp- } \\
\text { toms persisted despite conservative man- } \\
\text { agement." } \\
\text { Quote: "Patients with systemic or vascular } \\
\text { disease were excluded." }\end{array}$ \\
\hline $\begin{array}{l}\text { Outcome assessor blinded? } \\
\text { All outcomes }\end{array}$ & Unclear risk & No details were given. \\
\hline $\begin{array}{l}\text { Participant blinded? } \\
\text { All outcomes }\end{array}$ & High risk & This was not reported. \\
\hline $\begin{array}{l}\text { Intention-to-treat? } \\
\text { All outcomes }\end{array}$ & High risk & Not all of the participants were analysed. \\
\hline $\begin{array}{l}\text { Withdrawals or dropouts? } \\
\text { All outcomes }\end{array}$ & High risk & $\begin{array}{l}62 \text { participants were lost to follow up } \\
(28 \%) \text {, but no reasons were given }\end{array}$ \\
\hline
\end{tabular}


Gem 1990b

\begin{tabular}{|c|c|c|}
\hline Methods & \multicolumn{2}{|c|}{ This was a randomised prospective study (UK). } \\
\hline Participants & \multicolumn{2}{|c|}{ - 203 participants were randomly allocated. } \\
\hline Interventions & \multicolumn{2}{|c|}{$\begin{array}{l}\text { A: chemical ablation with a } 2 \text {-minute application of } 10 \% \text { sodium hydroxide (110) } \\
\text { B: chemical ablation with a } 1 \text {-minute application of } 10 \% \text { sodium hydroxide (93) }\end{array}$} \\
\hline Outcomes & \multicolumn{2}{|c|}{$\begin{array}{l}\text { Outcomes of the trial } \\
\text { 1) Recurrence } \\
\text { 2) Time to become pain free } \\
\text { 3) Healing time }\end{array}$} \\
\hline Notes & \multicolumn{2}{|c|}{ There was a large loss to follow up: $42 \%$. } \\
\hline \multicolumn{3}{|l|}{ Risk of bias } \\
\hline Bias & Authors' judgement & Support for judgement \\
\hline $\begin{array}{l}\text { Random sequence generation (selection } \\
\text { bias) }\end{array}$ & Unclear risk & No details were given. \\
\hline Allocation concealment (selection bias) & Unclear risk & No details were given. \\
\hline Selective reporting (reporting bias) & Unclear risk & This was unclear. \\
\hline Other bias & Unclear risk & This was unclear. \\
\hline Inclusion and exclusion criteria? & Low risk & $\begin{array}{l}\text { Quote: “...patients were accepted...symp- } \\
\text { toms persisted despite conservative man- } \\
\text { agement...” } \\
\text { Quote: “...patients with systemic or vascu- } \\
\text { lar disease were excluded." }\end{array}$ \\
\hline $\begin{array}{l}\text { Outcome assessor blinded? } \\
\text { All outcomes }\end{array}$ & Unclear risk & No details were given. \\
\hline $\begin{array}{l}\text { Participant blinded? } \\
\text { All outcomes }\end{array}$ & High risk & This was not reported. \\
\hline $\begin{array}{l}\text { Intention-to-treat? } \\
\text { All outcomes }\end{array}$ & High risk & Not all of the participants were analysed. \\
\hline $\begin{array}{l}\text { Withdrawals or dropouts? } \\
\text { All outcomes }\end{array}$ & High risk & $\begin{array}{l}85 \text { participants were lost to follow up } \\
(42 \%) \text {, but no reasons were given }\end{array}$ \\
\hline
\end{tabular}


Gerritsma-Bleeker 2002

\begin{tabular}{|c|c|c|}
\hline Methods & \multicolumn{2}{|c|}{$\begin{array}{l}\text { This was a randomised controlled trial (Netherlands, Department of Orthopaedic } \\
\text { Surgery) }\end{array}$} \\
\hline Participants & \multicolumn{2}{|c|}{$\begin{array}{l}\text { - } 60 \text { consecutive participants, but } 2 \text { withdrew leaving } 58 \text { participants, with a total } \\
\text { of } 63 \text { ingrowing toenails (age range }=9 \text { to } 76 \text { years, } \mathrm{M} / \mathrm{F}=30 / 33 \text { ) }\end{array}$} \\
\hline Interventions & \multicolumn{2}{|c|}{$\begin{array}{l}\text { A: partial matrix excision }(34) \\
\text { B: phenolization }(31)\end{array}$} \\
\hline Outcomes & \multicolumn{2}{|c|}{$\begin{array}{l}\text { Outcomes of the trial } \\
\text { 1) Recurrence after } 13 \text { months } \\
\text { 2) Postoperative morbidity (pain, wound exudates, scar tissue) } \\
\text { 3) Time to complete recovery (wearing shoes, return to normal activities/work) }\end{array}$} \\
\hline Notes & \multicolumn{2}{|l|}{-} \\
\hline \multicolumn{3}{|l|}{ Risk of bias } \\
\hline Bias & Authors' judgement & Support for judgement \\
\hline $\begin{array}{l}\text { Random sequence generation (selection } \\
\text { bias) }\end{array}$ & Unclear risk & No details were given. \\
\hline Allocation concealment (selection bias) & Unclear risk & $\begin{array}{l}\text { Third party randomisation was not explic- } \\
\text { itly stated. }\end{array}$ \\
\hline Selective reporting (reporting bias) & Unclear risk & This was not reported. \\
\hline Other bias & High risk & $\begin{array}{l}\text { There was only } 1 \text { bilateral procedure in } 1 \\
\text { participant. }\end{array}$ \\
\hline Inclusion and exclusion criteria? & Low risk & $\begin{array}{l}\text { Quote: "All patients with ingrowing toenail } \\
\text { of the hallux, who also had...were included. } \\
\text { ” } \\
\text { Quote: "Patients with diabetes...excluded. } \\
\text { ” }\end{array}$ \\
\hline $\begin{array}{l}\text { Outcome assessor blinded? } \\
\text { All outcomes }\end{array}$ & Low risk & $\begin{array}{l}\text { Quote: "Examinations were done by inde- } \\
\text { pendent observers." }\end{array}$ \\
\hline $\begin{array}{l}\text { Participant blinded? } \\
\text { All outcomes }\end{array}$ & High risk & This was not reported. \\
\hline $\begin{array}{l}\text { Intention-to-treat? } \\
\text { All outcomes }\end{array}$ & High risk & $\begin{array}{l}\text { Quote: "Evaluation was oriented to each } \\
\text { procedure separately, so we concentrated } \\
\text { the evaluation of the outcomes on } 63 \text { pro- } \\
\text { cedures." }\end{array}$ \\
\hline
\end{tabular}


Gerritsma-Bleeker 2002 (Continued)

\begin{tabular}{|c|c|c|}
\hline $\begin{array}{l}\text { Withdrawals or dropouts? } \\
\text { All outcomes }\end{array}$ & Low risk & $\begin{array}{l}\text { In total, } 8 / 60 \text { participants withdrew - } 2 \text { be- } \\
\text { cause of personal reasons, and } 6 \text { because of } \\
\text { an ineffective intervention }\end{array}$ \\
\hline
\end{tabular}

\section{Greig 1991a}

Methods

Participants

This was a randomised controlled trial (Scotland, Hairmyres Hospital Glasgow)

- 204 procedures on 168 participants (age range $=12$ to 77 years, $\mathrm{M} / \mathrm{F}=113 / 50$ ) referred to hospital during 1 year and for whom conservative treatment had failed.

$\begin{array}{ll}\text { Interventions } & \text { A: nail edge excision (47) } \\ & \text { B: total nail avulsion (59) } \\ \text { C: nail edge excision and phenol (57) }\end{array}$

Outcomes

Outcomes of the trial

1) Symptomatic recurrence

2) Total recurrence after 12 months

3) Postoperative infection after 2 weeks

4) Participant satisfaction

Notes

Risk of bias

\begin{tabular}{|c|c|c|}
\hline Bias & Authors' judgement & Support for judgement \\
\hline $\begin{array}{l}\text { Random sequence generation (selection } \\
\text { bias) }\end{array}$ & Unclear risk & No details were given. \\
\hline Allocation concealment (selection bias) & Unclear risk & No details were given. \\
\hline Selective reporting (reporting bias) & Unclear risk & This was unclear. \\
\hline Other bias & Unclear risk & This was unclear. \\
\hline Inclusion and exclusion criteria? & Low risk & $\begin{array}{l}\text { Quote: "...included all patients with in- } \\
\text { growing toenails." } \\
\text { Quote: "Recurrent ingrowing or ony- } \\
\text { chogryphotic toenails were excluded." }\end{array}$ \\
\hline $\begin{array}{l}\text { Outcome assessor blinded? } \\
\text { All outcomes }\end{array}$ & Low risk & $\begin{array}{l}\text { The first observation was done by the sur- } \\
\text { geon. The final assessment was done by an } \\
\text { independent assessor }\end{array}$ \\
\hline $\begin{array}{l}\text { Participant blinded? } \\
\text { All outcomes }\end{array}$ & High risk & This was not reported. \\
\hline
\end{tabular}


Greig 1991a (Continued)

\begin{tabular}{|c|c|c|}
\hline $\begin{array}{l}\text { Intention-to-treat? } \\
\text { All outcomes }\end{array}$ & High risk & $\begin{array}{l}5 \text { participants were lost to follow up and } \\
\text { excluded from the final analysis }\end{array}$ \\
\hline $\begin{array}{l}\text { Withdrawals or dropouts? } \\
\text { All outcomes }\end{array}$ & High risk & $\begin{array}{l}5 / 168 \text { participants were lost to follow up, } \\
\text { but no reason was given }\end{array}$ \\
\hline
\end{tabular}

\section{Issa 1988}

\begin{tabular}{l|l}
\hline Methods & This was a randomised controlled trial (Ireland, Adelaide Hospital) \\
\hline Participants & $\begin{array}{l}\text { - } 170 \text { procedures on } 140 \text { participants (age range }=9 \text { to } 54 \text { years, M/F }=2.7: 1) \\
\text { referred from general practitioners and accident and emergency departments were } \\
\text { performed. }\end{array}$ \\
\hline Interventions & A: phenol (45) \\
B: winograd (42) \\
C: phenol and Winograd (53)
\end{tabular}

Outcomes

Outcomes of the trial

1) Recurrence (symptomatic or asymptomatic) after 6 months

2) Pain duration first week

3) Pain intensity (linear pain analogue scale)

\section{Notes}

\section{Risk of bias}

\begin{tabular}{lll}
\hline Bias & Authors' judgement & Support for judgement \\
\hline $\begin{array}{l}\text { Random sequence generation (selection } \\
\text { bias) }\end{array}$ & Low risk & Quote: "Random number generation...” \\
\hline Allocation concealment (selection bias) & Unclear risk & No details were given. \\
\hline Selective reporting (reporting bias) & Unclear risk & This was unclear. \\
\hline Other bias & Low risk & There was no baseline imbalance. \\
\hline \begin{tabular}{l} 
Inclusion and exclusion criteria? \\
\hline $\begin{array}{l}\text { Outcome assessor blinded? } \\
\text { All outcomes }\end{array}$
\end{tabular} High risk & No details were given. \\
\hline $\begin{array}{l}\text { Participant blinded? } \\
\text { All outcomes }\end{array}$ & High risk & No details were given. \\
\hline
\end{tabular}


Issa 1988 (Continued)

\begin{tabular}{|c|c|c|}
\hline $\begin{array}{l}\text { Intention-to-treat? } \\
\text { All outcomes }\end{array}$ & High risk & $\begin{array}{l}\text { Not all of the included participants were } \\
\text { included in the final analysis }\end{array}$ \\
\hline $\begin{array}{l}\text { Withdrawals or dropouts? } \\
\text { All outcomes }\end{array}$ & High risk & $\begin{array}{l}\text { There were } 2 / 140 \text { participants lost to fol- } \\
\text { low up, but no reasons were given }\end{array}$ \\
\hline
\end{tabular}

Kim 2003

\begin{tabular}{|c|c|c|}
\hline Methods & \multicolumn{2}{|c|}{ This was a randomised controlled trial (Korea, Chosun University Hospital) } \\
\hline Participants & \multicolumn{2}{|c|}{$\begin{array}{l}-57 \text { participants were included }(\mathrm{M} / \mathrm{F}=19 / 38) \text { and treated with the nail splinting } \\
\text { technique. Age was not reported. }\end{array}$} \\
\hline Interventions & \multicolumn{2}{|c|}{$\begin{array}{l}\text { A gutter is placed over the ingrowing nail side } \\
\text { A: gutter removal after } 3 \text { days ( } 28) \\
\text { B: gutter removal after } 2 \text { weeks (29) }\end{array}$} \\
\hline Outcomes & \multicolumn{2}{|c|}{$\begin{array}{l}\text { Outcomes of the trial } \\
\text { 1) Recurrence after } 12 \text { months } \\
\text { 2) Tissue status } \\
\text { 3) Pain after } 1 \text { and } 2 \text { weeks and } 1 \text { month }\end{array}$} \\
\hline Notes & \multicolumn{2}{|l|}{-} \\
\hline \multicolumn{3}{|l|}{ Risk of bias } \\
\hline Bias & Authors' judgement & Support for judgement \\
\hline $\begin{array}{l}\text { Random sequence generation (selection } \\
\text { bias) }\end{array}$ & Unclear risk & No details were given. \\
\hline Allocation concealment (selection bias) & Unclear risk & No details were given. \\
\hline Selective reporting (reporting bias) & Unclear risk & This was unclear. \\
\hline Other bias & Unclear risk & This was unclear. \\
\hline Inclusion and exclusion criteria? & High risk & This was not reported. \\
\hline $\begin{array}{l}\text { Outcome assessor blinded? } \\
\text { All outcomes }\end{array}$ & Unclear risk & No details were given. \\
\hline $\begin{array}{l}\text { Participant blinded? } \\
\text { All outcomes }\end{array}$ & High risk & This was not reported. \\
\hline $\begin{array}{l}\text { Intention-to-treat? } \\
\text { All outcomes }\end{array}$ & Low risk & $\begin{array}{l}\text { All included participants were included in } \\
\text { the final analysis }\end{array}$ \\
\hline
\end{tabular}


Kim 2003 (Continued)

\begin{tabular}{l|l|l}
$\begin{array}{l}\text { Withdrawals or dropouts? } \\
\text { All outcomes }\end{array}$ & Low risk & There were no dropouts. \\
\hline
\end{tabular}

Kruijff 2008

\begin{tabular}{|c|c|c|}
\hline Methods & \multicolumn{2}{|c|}{ This was a randomised controlled trial (Netherlands, Departments of Surgery) } \\
\hline Participants & \multicolumn{2}{|c|}{$\begin{array}{l}\text { - } 105 \text { participants with } 109 \text { ingrown toenails }(\mathrm{M} / \mathrm{F}=73 / 36 \text {, mean age }=25 / 33 \\
\text { years) were included. }\end{array}$} \\
\hline Interventions & \multicolumn{2}{|c|}{$\begin{array}{l}\text { A: partial matrix excision }(58) \\
\text { B: orthonyxia }(51)\end{array}$} \\
\hline Outcomes & \multicolumn{2}{|c|}{$\begin{array}{l}\text { Outcomes of the trial } \\
\text { 1) Recurrence after } 12 \text { months } \\
\text { 2) Postoperative complications (infection, bleeding) after } 1 \text { week } \\
\text { 3) Return to normal activities/wearing shoes }\end{array}$} \\
\hline Notes & \multicolumn{2}{|l|}{-} \\
\hline \multicolumn{3}{|l|}{ Risk of bias } \\
\hline Bias & Authors' judgement & Support for judgement \\
\hline $\begin{array}{l}\text { Random sequence generation (selection } \\
\text { bias) }\end{array}$ & Unclear risk & This was not reported. \\
\hline Allocation concealment (selection bias) & Unclear risk & $\begin{array}{l}\text { Third party independent randomisation } \\
\text { was not mentioned. }\end{array}$ \\
\hline Selective reporting (reporting bias) & Unclear risk & This was unclear. \\
\hline Other bias & Low risk & There was no baseline imbalance. \\
\hline Inclusion and exclusion criteria? & Low risk & $\begin{array}{l}\text { Quote: "All patients with ingrown toenail. } \\
\text {..” } \\
\text { Quote: "We excluded patients..." }\end{array}$ \\
\hline $\begin{array}{l}\text { Outcome assessor blinded? } \\
\text { All outcomes }\end{array}$ & Low risk & $\begin{array}{l}\text { Examination of long-term outcomes was } \\
\text { done by independent observers who were } \\
\text { unaware which of the procedures had been } \\
\text { carried out }\end{array}$ \\
\hline $\begin{array}{l}\text { Participant blinded? } \\
\text { All outcomes }\end{array}$ & High risk & This was not reported. \\
\hline $\begin{array}{l}\text { Intention-to-treat? } \\
\text { All outcomes }\end{array}$ & High risk & $\begin{array}{l}\text { Not all included participants were included } \\
\text { in the final analysis }\end{array}$ \\
\hline
\end{tabular}




\section{Kruijff 2008 (Continued)}

Withdrawals or dropouts?

All outcomes
High risk

5 participants were lost to follow up - 2 participants withdrew. No reasons were given

\section{Leahy 1990}

\begin{tabular}{l|l} 
Methods & This was a randomised controlled trial (Ireland, Department of Surgery) \\
\hline Participants & $\begin{array}{l}\text { - } 68 \text { participants (mean age = 24 years in each group) with symptoms for more than } \\
1 \text { month who were referred to hospital over a fixed 6-month period }\end{array}$ \\
\hline Interventions & $\begin{array}{l}\text { A: phenol (32) } \\
\text { B: wedge excision (34) }\end{array}$ \\
\hline Outcomes & $\begin{array}{l}\text { Outcomes of the trial } \\
\text { 1) Symptomatic recurrence after } 16 \text { months } \\
\text { 2) Asymptomatic recurrence after } 16 \text { months } \\
\text { 3) Postoperative infection } \\
\text { 4) Postoperative haemorrhage } \\
\text { 5) Degree of pain } \\
\text { 6) Participant satisfaction }\end{array}$ \\
\hline Notes & - \\
\hline
\end{tabular}

\section{Risk of bias}

\begin{tabular}{|c|c|c|}
\hline Bias & Authors' judgement & Support for judgement \\
\hline $\begin{array}{l}\text { Random sequence generation (selection } \\
\text { bias) }\end{array}$ & Unclear risk & No details were given. \\
\hline Allocation concealment (selection bias) & Unclear risk & $\begin{array}{l}\text { It is not clear if sealed, consecutively num- } \\
\text { bered envelopes were used }\end{array}$ \\
\hline Selective reporting (reporting bias) & Unclear risk & This was unclear. \\
\hline Other bias & Low risk & $\begin{array}{l}\text { Gender imbalance does not appear to be } \\
\text { clinically relevant. }\end{array}$ \\
\hline Inclusion and exclusion criteria? & High risk & $\begin{array}{l}\text { Inclusion criteria are mentioned, but not } \\
\text { exclusion criteria }\end{array}$ \\
\hline $\begin{array}{l}\text { Outcome assessor blinded? } \\
\text { All outcomes }\end{array}$ & Low risk & $\begin{array}{l}\text { Quote: “...patients were examined by an } \\
\text { independent observer." }\end{array}$ \\
\hline $\begin{array}{l}\text { Participant blinded? } \\
\text { All outcomes }\end{array}$ & High risk & This was not reported. \\
\hline
\end{tabular}


Leahy 1990 (Continued)

\begin{tabular}{|c|c|c|}
\hline $\begin{array}{l}\text { Intention-to-treat? } \\
\text { All outcomes }\end{array}$ & High risk & $\begin{array}{l}\text { Not all included participants were included } \\
\text { in the final analysis }\end{array}$ \\
\hline $\begin{array}{l}\text { Withdrawals or dropouts? } \\
\text { All outcomes }\end{array}$ & High risk & $\begin{array}{l}\text { There were } 2 / 68 \text { participants lost to follow } \\
\text { up, but no reasons were given }\end{array}$ \\
\hline
\end{tabular}

McIntosh 2006

\begin{tabular}{l|l}
\hline Methods & This was a randomised controlled trial (UK, general hospital setting) \\
\hline Participants & $\begin{array}{c}\text { - } 100 \text { participants with ingrown toenails older than } 16 \text { years were included (M/F = } \\
\text { 42/58). Mean age was reported for both groups separately. All participants underwent } \\
\text { toenail surgery. }\end{array}$ \\
\hline Interventions & $\begin{array}{l}\text { A: honey dressing (52) } \\
\text { B: paraffin tulle gras dressing following toenail surgery (48) }\end{array}$ \\
\hline Outcomes & $\begin{array}{l}\text { Outcomes of the trial } \\
\text { 1) Pain (visual analogue scale) } \\
\text { 2) Time to heal in days }\end{array}$ \\
\hline Notes & - \\
\hline
\end{tabular}

\section{Risk of bias}

\begin{tabular}{|c|c|c|}
\hline Bias & Authors' judgement & Support for judgement \\
\hline $\begin{array}{l}\text { Random sequence generation (selection } \\
\text { bias) }\end{array}$ & Unclear risk & This was not reported. \\
\hline Allocation concealment (selection bias) & Low risk & $\begin{array}{l}\text { Quote: “...a telephone call to an indepen- } \\
\text { dent assistant located outside of the study } \\
\text { setting..." }\end{array}$ \\
\hline Selective reporting (reporting bias) & Unclear risk & This was unclear. \\
\hline Other bias & Low risk & $\begin{array}{l}\text { Gender imbalance does not seem to be clin- } \\
\text { ically relevant. }\end{array}$ \\
\hline Inclusion and exclusion criteria? & Low risk & $\begin{array}{l}\text { Quote: "Patients who matched the inclu- } \\
\text { sion criteria..." } \\
\text { Quote: "Exclusion criteria were..." }\end{array}$ \\
\hline $\begin{array}{l}\text { Outcome assessor blinded? } \\
\text { All outcomes }\end{array}$ & Low risk & $\begin{array}{l}\text { Quote: "The outcome assessor was blinded } \\
\text { for the intervention." }\end{array}$ \\
\hline
\end{tabular}


McIntosh 2006 (Continued)

\begin{tabular}{|c|c|c|}
\hline $\begin{array}{l}\text { Participant blinded? } \\
\text { All outcomes }\end{array}$ & Low risk & $\begin{array}{l}\text { Quote: "The patient was blinded for the } \\
\text { intervention." }\end{array}$ \\
\hline $\begin{array}{l}\text { Intention-to-treat? } \\
\text { All outcomes }\end{array}$ & High risk & $\begin{array}{l}13 / 100 \text { participants were not included in } \\
\text { the final analysis. }\end{array}$ \\
\hline $\begin{array}{l}\text { Withdrawals or dropouts? } \\
\text { All outcomes }\end{array}$ & Low risk & $\begin{array}{l}6 / 100 \text { participants were lost to follow up, } \\
\text { and } 7 / 100 \text { participants withdrew because } \\
\text { of non-concordance }\end{array}$ \\
\hline
\end{tabular}

\section{Morkane 1984}

\begin{tabular}{l|l}
\hline Methods & This was a randomised controlled trial (New Zealand, Christchurch Hospital) \\
\hline Participants & $\begin{array}{l}\text { - } 107 \text { procedures on } 103 \text { participants }(\mathrm{M} / \mathrm{F}=3.5 / 1) \text { referred from general } \\
\text { practitioners and accident and emergency departments who have had symptoms for } \\
\text { longer than } 2 \text { months. } \\
\text { Participants who had undergone surgery previously were excluded }\end{array}$ \\
\hline Interventions & $\begin{array}{l}\text { A: phenol (54) } \\
\text { B: winograd (53) }\end{array}$ \\
\hline
\end{tabular}

Outcomes $\quad$ Outcomes of the trial

1) Recurrence (symptomatic or asymptomatic) after 14 months

2) Pain intensity (linear analogue scale) at 1 week (Wilcoxon Rank Sum Test used)

Notes
Risk of bias

\begin{tabular}{|c|c|c|}
\hline Bias & Authors' judgement & Support for judgement \\
\hline $\begin{array}{l}\text { Random sequence generation (selection } \\
\text { bias) }\end{array}$ & Unclear risk & No details were given. \\
\hline Allocation concealment (selection bias) & Unclear risk & No details were given. \\
\hline Selective reporting (reporting bias) & Unclear risk & This was unclear. \\
\hline Other bias & Unclear risk & No details were given. \\
\hline Inclusion and exclusion criteria? & Low risk & $\begin{array}{l}\text { Quote: "Operative treatment...ingrowing } \\
\text { toenail longer than } 2 \text { months." } \\
\text { Quote: "Patients with shorter...treated by } \\
\text { conservative measures." } \\
\text { Quote: "...previously undergone surgery } \\
\text { were excluded." }\end{array}$ \\
\hline
\end{tabular}


Morkane 1984 (Continued)

\begin{tabular}{|c|c|c|}
\hline $\begin{array}{l}\text { Outcome assessor blinded? } \\
\text { All outcomes }\end{array}$ & Unclear risk & $\begin{array}{l}\text { Quote: "Patients were seen at...after treat- } \\
\text { ment." }\end{array}$ \\
\hline $\begin{array}{l}\text { Participant blinded? } \\
\text { All outcomes }\end{array}$ & High risk & This was not reported. \\
\hline $\begin{array}{l}\text { Intention-to-treat? } \\
\text { All outcomes }\end{array}$ & Low risk & There were no withdrawals or dropouts. \\
\hline $\begin{array}{l}\text { Withdrawals or dropouts? } \\
\text { All outcomes }\end{array}$ & Low risk & There were no withdrawals or dropouts. \\
\hline
\end{tabular}

\section{Perry 1984}

\begin{tabular}{l|l} 
Methods & This was a randomised controlled trial (UK, Leicester Royal Infirmary) \\
\hline Participants & $\begin{array}{l}\bullet 84 \text { participants on whom } 135 \text { procedures were performed (age and sex were not } \\
\text { reported). }\end{array}$ \\
\hline Interventions & $\begin{array}{l}\text { A: insertion plastic gutter (33) } \\
\text { B: wedge resection (32) } \\
\text { C: radical excision of the nail fold (36) } \\
\text { D: plantar rotation of the nail fold (24) }\end{array}$ \\
\hline
\end{tabular}

Outcomes

Outcomes of the trial

1) Recurrence after 12 months

2) Time to heal in weeks (no standard deviations)

\section{Notes}

\section{Risk of bias}

\begin{tabular}{|c|c|c|}
\hline Bias & Authors' judgement & Support for judgement \\
\hline $\begin{array}{l}\text { Random sequence generation (selection } \\
\text { bias) }\end{array}$ & Unclear risk & No details were given. \\
\hline Allocation concealment (selection bias) & Unclear risk & No details were given. \\
\hline Selective reporting (reporting bias) & Unclear risk & This was unclear. \\
\hline Other bias & Unclear risk & No baseline characteristics were given. \\
\hline Inclusion and exclusion criteria? & High risk & $\begin{array}{l}\text { Neither inclusion nor exclusion criteria } \\
\text { were provided. }\end{array}$ \\
\hline $\begin{array}{l}\text { Outcome assessor blinded? } \\
\text { All outcomes }\end{array}$ & Unclear risk & No details were given. \\
\hline
\end{tabular}




\section{Perry 1984 (Continued)}

\begin{tabular}{l|l|l}
\hline $\begin{array}{l}\text { Participant blinded? } \\
\text { All outcomes }\end{array}$ & High risk & This was not reported. \\
\hline $\begin{array}{l}\text { Intention-to-treat? } \\
\text { All outcomes }\end{array}$ & Low risk & $\begin{array}{l}\text { All participants/procedures were included } \\
\text { in the final analysis, although this was not } \\
\text { stated }\end{array}$ \\
\hline $\begin{array}{l}\text { Withdrawals or dropouts? } \\
\text { All outcomes }\end{array}$ & High risk & $\begin{array}{l}20 / 84 \text { participants were lost to follow up, } \\
\text { but no reasons were given }\end{array}$ \\
\hline
\end{tabular}

\section{Reyzelman 2000}

\begin{tabular}{|c|c|c|}
\hline Methods & \multicolumn{2}{|c|}{ This was a randomised controlled trial (US, Department of Orthopaedics) } \\
\hline Participants & \multicolumn{2}{|c|}{ - 154 participants were included $(\mathrm{M} / \mathrm{F}=91 / 63$, mean age = 20/7 years $)$. } \\
\hline Interventions & \multicolumn{2}{|c|}{$\begin{array}{l}\text { A: } 1 \text { week of antibiotics and a chemical (phenol) matricectomy simultaneously (53) } \\
\text { B: antibiotics for } 1 \text { week and then a chemical matricectomy }(51) \\
\text { C: chemical matricectomy alone }(50)\end{array}$} \\
\hline Outcomes & \multicolumn{2}{|c|}{$\begin{array}{l}\text { Outcomes of the trial } \\
\text { 1) Time to heal in weeks } \\
\text { 2) Infection }\end{array}$} \\
\hline Notes & \multicolumn{2}{|l|}{ - } \\
\hline \multicolumn{3}{|l|}{ Risk of bias } \\
\hline Bias & Authors' judgement & Support for judgement \\
\hline $\begin{array}{l}\text { Random sequence generation (selection } \\
\text { bias) }\end{array}$ & Low risk & $\begin{array}{l}\text { Quote: “...computerized randomisation ta- } \\
\text { ble and variable block randomisation...” }\end{array}$ \\
\hline Allocation concealment (selection bias) & Unclear risk & No details were given. \\
\hline Selective reporting (reporting bias) & Unclear risk & This was unclear. \\
\hline Other bias & Unclear risk & This was unclear. \\
\hline Inclusion and exclusion criteria? & Low risk & $\begin{array}{l}\text { Quote: "All subjects had...” } \\
\text { Quote: "Patients with...were excluded." }\end{array}$ \\
\hline $\begin{array}{l}\text { Outcome assessor blinded? } \\
\text { All outcomes }\end{array}$ & Unclear risk & No details were given. \\
\hline $\begin{array}{l}\text { Participant blinded? } \\
\text { All outcomes }\end{array}$ & High risk & This was not reported. \\
\hline
\end{tabular}


Reyzelman 2000 (Continued)

\begin{tabular}{|c|c|c|}
\hline $\begin{array}{l}\text { Intention-to-treat? } \\
\text { All outcomes }\end{array}$ & High risk & $\begin{array}{l}6 / 154 \text { participants were not included in the } \\
\text { final analysis. }\end{array}$ \\
\hline $\begin{array}{l}\text { Withdrawals or dropouts? } \\
\text { All outcomes }\end{array}$ & High risk & $\begin{array}{l}\text { 6/154 participants were lost to follow up } \\
\text { but no reasons were given }\end{array}$ \\
\hline
\end{tabular}

Shaath 2005

\begin{tabular}{l|l}
\hline Methods & This was a randomised controlled trial (UK, Department of Orthopaedics) \\
\hline Participants & -105 participants $(\mathrm{M} / \mathrm{F}=53 / 30,22$ were lost to follow up, average age $=39.4)$ \\
\hline Interventions & $\begin{array}{l}\text { A: total nail ablation }(52) \\
\text { B: partial nail avulsion with chemical ablation by sodium hydroxide }(53)\end{array}$ \\
\hline
\end{tabular}

\begin{tabular}{|c|c|}
\hline Outcomes & $\begin{array}{l}\text { Outcomes of the trial } \\
\text { 1) Recurrence } \\
\text { 2) Postoperative pain } \\
\text { 3) Number of dressings } \\
\text { 4) Return to normal shoe wear } \\
\text { 5) Return to normal activity and work }\end{array}$ \\
\hline Notes & There was a large loss to follow up: $21 \%$ \\
\hline
\end{tabular}

\section{Risk of bias}

\begin{tabular}{|c|c|c|}
\hline Bias & Authors' judgement & Support for judgement \\
\hline $\begin{array}{l}\text { Random sequence generation (selection } \\
\text { bias) }\end{array}$ & Unclear risk & No details were given. \\
\hline Allocation concealment (selection bias) & Low risk & $\begin{array}{l}\text { Quote: "Once a patient...details sent to a } \\
\text { member of staff who was not taking part in } \\
\text { the research. The staff member kept all the } \\
\text { opaque envelopes for the randomization.. } \\
\text {.As each envelope was opened the partici- } \\
\text { pant was assigned to a list." }\end{array}$ \\
\hline Selective reporting (reporting bias) & Unclear risk & This was unclear. \\
\hline Other bias & Unclear risk & This was unclear. \\
\hline Inclusion and exclusion criteria? & Low risk & $\begin{array}{l}\text { Quote: “...only foot problems were ingrow- } \\
\text { ing toenails.” }\end{array}$ \\
\hline
\end{tabular}


Shaath 2005 (Continued)

\begin{tabular}{l|l|l}
\hline $\begin{array}{l}\text { Outcome assessor blinded? } \\
\text { All outcomes }\end{array}$ & Low risk & $\begin{array}{l}\text { Quote: "The patient was examined by a } \\
\text { nurse not taking part in the trial." } \\
\text { Quote: "Final assessment was done by a } \\
\text { midwife who had no training in the treat- } \\
\text { ment of ingrowing toenails." }\end{array}$ \\
\hline $\begin{array}{l}\text { Participant blinded? } \\
\text { All outcomes }\end{array}$ & High risk & This was not reported. \\
\hline $\begin{array}{l}\text { Intention-to-treat? } \\
\text { All outcomes }\end{array}$ & High risk & $\begin{array}{l}\text { Analysis was not undertaken using inten- } \\
\text { tion-to-treat. }\end{array}$ \\
\hline $\begin{array}{l}\text { Withdrawals or dropouts? } \\
\text { All outcomes }\end{array}$ & High risk & There was a 21\% loss to follow up. \\
\hline
\end{tabular}

Sykes $1988 b$

\begin{tabular}{l|l}
\hline Methods & This was a randomised controlled trial (UK, Department of Surgery) \\
\hline Participants & $\bullet 152$ participants were included. Age and sex were not reported. \\
\hline Interventions & $\begin{array}{l}\text { A: total phenolic ablation } \\
\text { B: total excision of the nail bed (Zadik's operation) }\end{array}$ \\
\hline Outcomes & $\begin{array}{l}\text { Outcomes of the trial } \\
\text { 1) Recurrence }\end{array}$ \\
\hline Notes & - \\
\hline
\end{tabular}

\section{Risk of bias}

\begin{tabular}{|c|c|c|}
\hline Bias & Authors' judgement & Support for judgement \\
\hline $\begin{array}{l}\text { Random sequence generation (selection } \\
\text { bias) }\end{array}$ & Unclear risk & No details were given. \\
\hline Allocation concealment (selection bias) & Unclear risk & No details were given. \\
\hline Selective reporting (reporting bias) & Unclear risk & This was unclear. \\
\hline Other bias & Unclear risk & This was unclear. \\
\hline Inclusion and exclusion criteria? & High risk & $\begin{array}{l}\text { Neither inclusion nor exclusion criteria } \\
\text { were provided. }\end{array}$ \\
\hline $\begin{array}{l}\text { Outcome assessor blinded? } \\
\text { All outcomes }\end{array}$ & Unclear risk & No details were given. \\
\hline
\end{tabular}


Sykes 1988b (Continued)

\begin{tabular}{lll}
\hline $\begin{array}{l}\text { Participant blinded? } \\
\text { All outcomes }\end{array}$ & High risk & This was not reported. \\
\hline $\begin{array}{l}\text { Intention-to-treat? } \\
\text { All outcomes }\end{array}$ & Unclear risk & No details were given. \\
\hline $\begin{array}{l}\text { Withdrawals or dropouts? } \\
\text { All outcomes }\end{array}$ & High risk & $\begin{array}{l}\text { There was no description of withdrawals } \\
\text { and/or dropouts. }\end{array}$ \\
\hline
\end{tabular}

\section{Sykes 1988c}

\begin{tabular}{l|l}
\hline Methods & This was a randomised controlled trial (UK, Department of Surgery) \\
\hline Participants & $\begin{array}{l}\text { - } 424 \text { participants were included. Age and sex were not reported. The participants } \\
\text { allocated to receive segmental phenolic ablation were added to the participants } \\
\text { presenting to chiropodists. From this common pool, participants were randomly } \\
\text { allocated to surgeons or chiropodists. }\end{array}$ \\
\hline Interventions & $\begin{array}{l}\text { A: nail avulsion (45) } \\
\text { B: segmental phenolic ablation by chiropodist (182) } \\
\text { C: segmental phenolic ablation by surgeon (197) }\end{array}$ \\
\hline
\end{tabular}

Outcomes

Outcomes of the trial

1) Recurrence after 12 months

Notes

Because of preliminary disappointing results in the avulsion group, they stopped assigning participants to this group

\section{Risk of bias}

\begin{tabular}{|c|c|c|}
\hline Bias & Authors' judgement & Support for judgement \\
\hline $\begin{array}{l}\text { Random sequence generation (selection } \\
\text { bias) }\end{array}$ & Unclear risk & No details were given. \\
\hline Allocation concealment (selection bias) & Unclear risk & No details were given. \\
\hline Selective reporting (reporting bias) & Unclear risk & This was unclear. \\
\hline Other bias & High risk & $\begin{array}{l}\text { Due to unsatisfying results in } 1 \text { arm (avul- } \\
\text { sion by chiropodists), investigators decided } \\
\text { to close this arm, which resulted in a higher } \\
\text { number of participants in the other arms }\end{array}$ \\
\hline Inclusion and exclusion criteria? & High risk & $\begin{array}{l}\text { Neither inclusion nor exclusion criteria } \\
\text { were provided. }\end{array}$ \\
\hline
\end{tabular}


Sykes 1988c (Continued)

\begin{tabular}{l|l|l}
\hline $\begin{array}{l}\text { Outcome assessor blinded? } \\
\text { All outcomes }\end{array}$ & Unclear risk & No details were given. \\
\hline $\begin{array}{l}\text { Participant blinded? } \\
\text { All outcomes }\end{array}$ & High risk & No details were given. \\
\hline $\begin{array}{l}\text { Intention-to-treat? } \\
\text { All outcomes }\end{array}$ & High risk & $\begin{array}{l}\text { Not all included participants were included } \\
\text { in the final analysis }\end{array}$ \\
\hline $\begin{array}{l}\text { Withdrawals or dropouts? } \\
\text { All outcomes }\end{array}$ & High risk & $\begin{array}{l}7,37, \text { and } 35 \text { participants were lost to fol- } \\
\text { low up/result not known, but no reasons } \\
\text { were given }\end{array}$ \\
\hline
\end{tabular}

van der Ham 1990

\begin{tabular}{|c|c|c|}
\hline Methods & \multicolumn{2}{|c|}{ This was a randomised controlled trial (Netherlands, Department of General Surgery) } \\
\hline Participants & \multicolumn{2}{|c|}{$\begin{array}{l}\text { - } 249 \text { participants (age range }=3 \text { to } 97 \text { years, } \mathrm{M} / \mathrm{F}=158 / 91 \text { ) referred by general } \\
\text { practitioners } \\
\text { Participants who had undergone previous surgery were excluded }\end{array}$} \\
\hline Interventions & \multicolumn{2}{|c|}{$\begin{array}{l}\text { A: phenol (125) } \\
\text { B; wedge excision (124) }\end{array}$} \\
\hline Outcomes & \multicolumn{2}{|c|}{$\begin{array}{l}\text { Outcomes of the trial } \\
\text { 1) Recurrence } \\
\text { 2) Re-operation required } \\
\text { 3) Healing time (no standard deviation reported) } \\
\text { 4) Pain relief required } \\
\text { 5) Time required off work }\end{array}$} \\
\hline Notes & \multicolumn{2}{|l|}{-} \\
\hline \multicolumn{3}{|l|}{ Risk of bias } \\
\hline Bias & Authors' judgement & Support for judgement \\
\hline $\begin{array}{l}\text { Random sequence generation (selection } \\
\text { bias) }\end{array}$ & Unclear risk & No details were given. \\
\hline Allocation concealment (selection bias) & Unclear risk & $\begin{array}{l}\text { It is not clear if sealed, consecutively num- } \\
\text { bered envelopes were used }\end{array}$ \\
\hline Selective reporting (reporting bias) & Unclear risk & This was unclear. \\
\hline Other bias & Unclear risk & This was unclear. \\
\hline
\end{tabular}


van der Ham 1990 (Continued)

\begin{tabular}{l|l|l}
\hline Inclusion and exclusion criteria? & Low risk & $\begin{array}{l}\text { Quote: "Patients with ingrowing toenails } \\
\text { are included." } \\
\text { Quote: “..excluded if they had recurrence } \\
\text { after previous surgery." }\end{array}$ \\
\hline $\begin{array}{l}\text { Outcome assessor blinded? } \\
\text { All outcomes }\end{array}$ & High risk & The outcome assessors were not blinded. \\
\hline $\begin{array}{l}\text { Participant blinded? } \\
\text { All outcomes }\end{array}$ & High risk & Tow risk \\
\hline $\begin{array}{l}\text { Intention-to-treat? } \\
\text { All outcomes }\end{array}$ & This not reported. \\
\hline $\begin{array}{l}\text { Withdrawals or dropouts? } \\
\text { All outcomes }\end{array}$ & High risk & $\begin{array}{l}\text { Although not stated, recurrence was calcu- } \\
\text { lated using the number of participants at } \\
\text { the start of the study }\end{array}$ \\
\hline
\end{tabular}

\section{Varma 1983}

\section{Methods}

Participants

This was a randomised controlled trial (UK, Department of Surgery)

- 67 participants undergoing ingrown toenail surgery during a fixed 8-month period (age and sex were not reported).

$\begin{array}{ll}\text { Interventions } & \text { A: standard surgical wedge excision (35) } \\ \text { B: phenol wedge cauterisation (28) }\end{array}$

Outcomes

\section{Outcomes of the trial}

1) Symptomatic recurrence at least 6 months

2) Total recurrence after 6 months

3) Healing time (no standard deviation reported)

\section{Notes}

\section{Risk of bias}

\begin{tabular}{l|l|l}
\hline Bias & Authors' judgement & Support for judgement \\
\hline $\begin{array}{l}\text { Random sequence generation (selection } \\
\text { bias) }\end{array}$ & Unclear risk & No details were given. \\
\hline Allocation concealment (selection bias) & Unclear risk & $\begin{array}{l}\text { It is not clear if sealed, consecutively num- } \\
\text { bered envelopes were used }\end{array}$
\end{tabular}


Varma 1983 (Continued)

\begin{tabular}{l|l|l}
\hline Selective reporting (reporting bias) & Unclear risk & This was unclear. \\
\hline Other bias & Unclear risk & This was unclear. \\
\hline $\begin{array}{l}\text { Inclusion and exclusion criteria? } \\
\begin{array}{l}\text { Outcome assessor blinded? } \\
\text { All outcomes }\end{array}\end{array}$ & High risk & $\begin{array}{l}\text { Neither inclusion nor exclusion criteria } \\
\text { were provided. }\end{array}$ \\
\hline $\begin{array}{l}\text { Participant blinded? } \\
\text { All outcomes }\end{array}$ & High risk & This was not reported. \\
\hline $\begin{array}{l}\text { Intention-to-treat? } \\
\text { All outcomes }\end{array}$ & High risk & This was not reported. \\
\hline $\begin{array}{l}\text { Withdrawals or dropouts? } \\
\text { All outcomes }\end{array}$ & High risk & $\begin{array}{l}\text { There were } 4 / 67 \text { participants not included } \\
\text { in the final analysis }\end{array}$ \\
\hline
\end{tabular}

\section{Wallace 1979b}

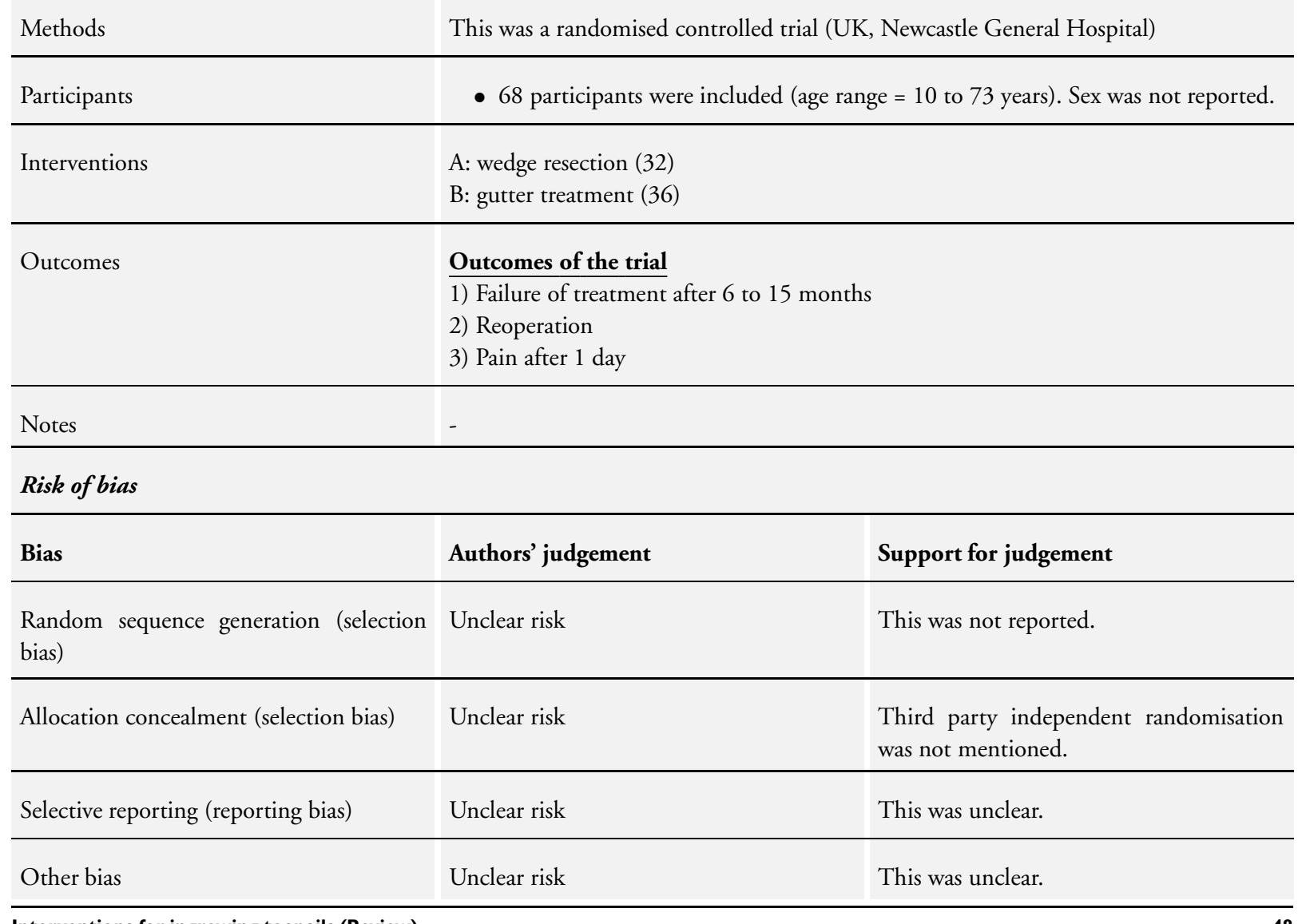


Wallace 1979b (Continued)

\begin{tabular}{|c|c|c|}
\hline Inclusion and exclusion criteria? & Low risk & $\begin{array}{l}\text { Quote: "Patients were selected using the } \\
\text { following criteria..." }\end{array}$ \\
\hline $\begin{array}{l}\text { Outcome assessor blinded? } \\
\text { All outcomes }\end{array}$ & Low risk & $\begin{array}{l}\text { Quote: "An independent observer exam- } \\
\text { ined the patients..." }\end{array}$ \\
\hline $\begin{array}{l}\text { Participant blinded? } \\
\text { All outcomes }\end{array}$ & High risk & This was not reported. \\
\hline $\begin{array}{l}\text { Intention-to-treat? } \\
\text { All outcomes }\end{array}$ & Low risk & $\begin{array}{l}\text { All included participants were included in } \\
\text { the final analysis }\end{array}$ \\
\hline $\begin{array}{l}\text { Withdrawals or dropouts? } \\
\text { All outcomes }\end{array}$ & Low risk & $\begin{array}{l}\text { There were no withdrawals and/or drop- } \\
\text { outs. }\end{array}$ \\
\hline
\end{tabular}

Characteristics of excluded studies [ordered by study ID]

\begin{tabular}{|c|c|}
\hline Study & Reason for exclusion \\
\hline Aksahal 2001 & This was not a randomised controlled trial. \\
\hline Andrew 1979 & Participants were quasi-randomised (based on an odd or even number) \\
\hline Arai 2004 & This was not a randomised controlled trial. \\
\hline Boberg 2002 & The study was not about an ingrowing toenail. \\
\hline Bossers 1992 & Participants were quasi-randomised (based on their date of birth) \\
\hline Bostanci 2007 & Participants were quasi-randomised (based on their attendance at the surgery unit) \\
\hline Burssens 1987 & Participants were quasi-randomised (based on an odd or even number) \\
\hline Cameron 1981 & Participants were randomised (based on the stage of their ingrown toenail) \\
\hline Córdoba-Fernandez 2008 & The follow-up period was shorter than 1 month. \\
\hline Foley 1994 & There was no obvious distinction between onychocryptosis and onychogryphosis \\
\hline Greig 1991b & $\begin{array}{l}2 \text { studies were reported in the same paper. The second study was observational (not comparing inter- } \\
\text { ventions) }\end{array}$ \\
\hline Herold 2001 & Participants were quasi-randomised (based on their address). \\
\hline Holt 1987 & There was no obvious distinction between onychocryptosis and onychogryphosis \\
\hline
\end{tabular}


(Continued)

\begin{tabular}{ll}
\hline Kocyigit 2005 & Participants were quasi-randomised (based on their order of attendance) \\
\hline Schütte 1980 & This was a retrospective study. \\
\hline Sykes 1988a & This was not a trial (no comparison groups). \\
\hline Tada 2004 & This was not a randomised controlled trial. \\
\hline Tait 1987 & Participants were quasi-randomised (based on their date of birth) \\
\hline
\end{tabular}

Characteristics of studies awaiting assessment [ordered by study ID]

\section{Altinyazar 2010}

\begin{tabular}{|c|c|}
\hline Methods & The participants were randomly divided into 2 groups. \\
\hline Participants & - 44 participants with ingrown toenails were randomly divided into 2 groups. \\
\hline Interventions & $\begin{array}{l}\text { Intervention } \\
\text { A: lidocaine with epinephrine } \\
\text { Control intervention } \\
\text { B: lidocaine without epinephrine } \\
\text { The plain lidocaine group }(\mathrm{n}=22) \text { underwent digital anaesthesia using } 2 \% \text { plain lidocaine, and the lidocaine with } \\
\text { epinephrine group }(\mathrm{n}=22) \text { underwent digital anaesthesia with } 2 \% \text { lidocaine with } 1: 100,000 \text { epinephrine } \\
\text { In the postoperative period, the participants were evaluated for pain, drainage, and peripheral tissue destruction and } \\
\text { were followed for up to } 18 \text { months for recurrence }\end{array}$ \\
\hline Outcomes & $\begin{array}{l}\text { Primary outcomes of the trial } \\
\text { 1) Recurrence } \\
\text { Secondary outcomes of the trial } \\
\text { 1) Pain }\end{array}$ \\
\hline Notes & - \\
\hline
\end{tabular}

\section{Peyvandi 2011}

\begin{tabular}{l|l}
\hline Methods & This was a prospective, randomised clinical trial. \\
\hline Participants & $\bullet 100$ participants aged 12 to 50 with a stage III ingrowing toenail of hallux. \\
\hline Interventions & $\frac{\text { Intervention }}{\text { A: wedge resection }}$ \\
& $\frac{\text { Control intervention }}{\text { B: gutter treatment }}$
\end{tabular}




\section{Peyvandi 2011 (Continued)}

\begin{tabular}{|c|c|}
\hline Outcomes & $\begin{array}{l}\text { Primary outcomes of the trial } \\
\text { 1) Recurrence } \\
\text { Secondary outcomes of the trial } \\
\text { 1) Postoperative infection }\end{array}$ \\
\hline Notes & - \\
\hline
\end{tabular}

\section{Tatlican 2009}

\begin{tabular}{|c|c|}
\hline Methods & This was a randomised controlled trial. \\
\hline Participants & - 110 participants with 148 ingrowing nails (grade 2 to 3$)(\mathrm{M} / \mathrm{F}=54 / 56)$. \\
\hline Interventions & $\begin{array}{l}\text { Intervention } \\
\text { A: } 1 \text { minute phenol } \\
\text { Control intervention } \\
\text { B: } 2 \text { and } 3 \text { minutes phenol } \\
\text { The participants were randomised to } 3 \text { groups for 1-, 2-, and 3-minute applications of phenol cauterisation of the } \\
\text { germinal matrix following surgical removal of ingrowing nails. Postoperative evaluations were made on days 2, 10, } \\
\text { 16, 24, and } 30 \text { for pain, drainage, and tissue damage. Recurrences were recorded during a follow-up of } 24 \text { months }\end{array}$ \\
\hline Outcomes & $\begin{array}{l}\text { Primary outcomes of the trial } \\
\text { 1) Recurrence } \\
\text { Secondary outcomes of the trial } \\
\text { 1) Postoperative pain }\end{array}$ \\
\hline Notes & The article was published in Turkish. \\
\hline
\end{tabular}

\section{Zaba 2002}

\begin{tabular}{l|l} 
Methods & This was a 3-arm randomised prospective study. \\
\hline Participants & $\bullet 34$ participants \\
\hline Interventions & $\begin{array}{l}\text { A: total nail edge excision } \\
\text { B: } \mathrm{CO}_{2} \text { laser } \\
\text { C: } \mathrm{Nd}: Y A G \text { laser therapy }\end{array}$ \\
\hline Outcomes & Primary outcomes of the trial \\
\hline 1) Recurrence
\end{tabular}


Characteristics of ongoing studies [ordered by study ID]

\section{ISRCTN32883274}

\begin{tabular}{|c|c|}
\hline Trial name or title & Radio surgery versus $80 \%$ phenol for toe nail matrix ablation: a randomised comparison study \\
\hline Methods & This is a single-centre blinded randomised comparative trial \\
\hline Participants & $\begin{array}{l}\frac{\text { Planned }}{\bullet 60 \text { participants }} \\
\text { Inclusion criteria of the trial } \\
\text { - Participants aged } 18 \text { to } 88 \text { years with an ingrowing toenail or other nail conditions (involuted nail, } \\
\text { fungal infection, thickening or hypertrophy of the nail) }\end{array}$ \\
\hline Interventions & $\begin{array}{l}\text { Intervention } \\
\text { A: radio surgery } \\
\text { Control intervention } \\
\text { B: matrix ablation with phenol }\end{array}$ \\
\hline Outcomes & $\begin{array}{l}\text { Primary outcomes of the trial } \\
\text { 1) Recurrence } \\
\text { 2) Postoperative pain } \\
\text { 3) Postoperative infection } \\
\text { 4) Healing time } \\
\text { Secondary outcomes of the trial } \\
\text { 1) Not provided at time of registration }\end{array}$ \\
\hline Starting date & 1st September 2005 \\
\hline Contact information & $\begin{array}{l}\text { Mr Ian Robinson } \\
\text { Podiatry } \\
\text { Dean Clarke House } \\
\text { Southernhay East } \\
\text { dhmail@doh.gsi.org.uk }\end{array}$ \\
\hline Notes & The status of the trial is completed. \\
\hline
\end{tabular}

\section{NCT00641433}

Trial name or title Topical Collagen-Silver Versus Standard Care Following Phenol Ablation of Ingrown Nails: A Randomized Controlled Trial

Methods This is a randomised, single-blind, parallel study.

$\begin{array}{ll}\text { Participants } & \begin{array}{l}\text { Planned } \\ \bullet 80 \text { participants } \\ \text { Inclusion criteria of the trial }\end{array} \\ \bullet \text { Participants aged } 18 \text { years and older with ingrown toenails defined as any incurvated nail border that } \\ \text { digs into the skin of the nail fold and causes pain and discomfort } \\ \text { Exclusion criteria of the trial }\end{array}$


NCT00641433 (Continued)

- Participants with immunocompromised states (chronic steroid use, diabetes mellitus, collagen vascular disease, HIV infection)

\begin{tabular}{ll}
\hline Interventions & $\begin{array}{l}\text { Intervention } \\
\text { A: topical collagen-silver } \\
\text { Control intervention } \\
\text { B: standard care following phenol ablation of ingrown nails }\end{array}$ \\
\hline Outcomes & $\begin{array}{l}\text { Primary outcomes of the trial } \\
\text { 1) Healing time } \\
\text { Secondary outcomes of the trial }\end{array}$ \\
\hline Starting date & Days to recovery \\
\hline Contact information & $\begin{array}{l}\text { David G Armstrong, DPM, PhD } \\
\text { Rosalind Franklin University } \\
\text { david.armstrong@rosalindfranklin.edu } \\
847-578-8440\end{array}$ \\
\hline Notes & Contact with the author was sought, but it was not successful \\
\hline
\end{tabular}


DATA AND ANALYSES

Comparison 1. Non-surgical procedures

\begin{tabular}{lcccc} 
Outcome or subgroup title & $\begin{array}{c}\text { No. of } \\
\text { studies }\end{array}$ & $\begin{array}{c}\text { No. of } \\
\text { participants }\end{array}$ & Statistical method & Effect size \\
\hline $\begin{array}{c}\text { 1 Recurrence } \\
\text { 1.1 Gutter removal 3 days vs 2 } \\
\text { weeks after treatment }\end{array}$ & 1 & Risk Ratio (M-H, Random, 95\% CI) & Totals not selected \\
\end{tabular}

Comparison 2. Non-surgical vs surgical procedures

\begin{tabular}{lcccc} 
Outcome or subgroup title & $\begin{array}{c}\text { No. of } \\
\text { studies }\end{array}$ & $\begin{array}{c}\text { No. of } \\
\text { participants }\end{array}$ & Statistical method & Effect size \\
\hline $\begin{array}{l}\text { 1 Recurrence } \\
\quad \begin{array}{l}1.1 \text { Plastic gutter vs surgical } \\
\text { treatment }\end{array}\end{array}$ & 2 & 181 & $\begin{array}{l}\text { Risk Ratio (M-H, Random, 95\% CI) } \\
\text { Risk Ratio (M-H, Random, 95\% CI) }\end{array}$ & $\begin{array}{l}\text { Subtotals only } \\
1.2 \text { Orthonyxia vs part matr }\end{array}$ \\
\begin{tabular}{l} 
exc \\
\hline
\end{tabular}
\end{tabular}

Comparison 3. Surgical procedures: Chem abln \& surg vs surg proc

\begin{tabular}{|c|c|c|c|c|}
\hline Outcome or subgroup title & $\begin{array}{l}\text { No. of } \\
\text { studies }\end{array}$ & $\begin{array}{c}\text { No. of } \\
\text { participants }\end{array}$ & Statistical method & Effect size \\
\hline 1 Recurrence & 11 & & Risk Ratio (M-H, Random, 95\% CI) & Totals not selected \\
\hline $\begin{array}{l}\text { 1.1 PNA + Ph vs wedge + surg } \\
\text { ME }\end{array}$ & 5 & & Risk Ratio (M-H, Random, 95\% CI) & $0.0[0.0,0.0]$ \\
\hline 1.2 PNA + Ph vs nail edge exc & 1 & & Risk Ratio (M-H, Random, 95\% CI) & $0.0[0.0,0.0]$ \\
\hline 1.3 PNA + Ph vs total avul & 2 & & Risk Ratio (M-H, Random, 95\% CI) & $0.0[0.0,0.0]$ \\
\hline $\begin{array}{l}1.4 \mathrm{Ph}+\text { total avul vs total } \\
\text { avul + surg ME }\end{array}$ & 1 & & Risk Ratio (M-H, Random, 95\% CI) & $0.0[0.0,0.0]$ \\
\hline $\begin{array}{l}\text { 1.5 PNA + Ph vs PNA + Surg } \\
\text { ME }\end{array}$ & 2 & & Risk Ratio (M-H, Random, 95\% CI) & $0.0[0.0,0.0]$ \\
\hline 1.6 PNA + sod vs total avul & 1 & & Risk Ratio (M-H, Random, 95\% CI) & $0.0[0.0,0.0]$ \\
\hline 1.7 PNA + ph vs PNA & 1 & & Risk Ratio (M-H, Random, 95\% CI) & $0.0[0.0,0.0]$ \\
\hline 2 Pain of operation & 1 & & Risk Ratio (M-H, Random, 95\% CI) & Totals not selected \\
\hline $\begin{array}{l}2.1 \mathrm{PNA}+\mathrm{Ph} \text { vs wedge + surg } \\
\mathrm{ME}\end{array}$ & 1 & & Risk Ratio (M-H, Random, 95\% CI) & $0.0[0.0,0.0]$ \\
\hline 3 Postoperative infection & 4 & 407 & Risk Ratio (M-H, Random, 95\% CI) & $1.51[0.53,4.34]$ \\
\hline 3.1 PNA + Ph vs wedge + surg & 1 & 85 & Risk Ratio (M-H, Random, 95\% CI) & $1.57[0.37,6.60]$ \\
\hline
\end{tabular}




\begin{tabular}{|c|c|c|c|c|}
\hline 3.2 PNA + Ph vs nail edge exc & 1 & 104 & Risk Ratio (M-H, Random, 95\% CI) & $5.77[0.74,45.26]$ \\
\hline 3.3 PNA + Ph vs total avul & 1 & 116 & Risk Ratio (M-H, Random, 95\% CI) & $15.52[0.91,265.55]$ \\
\hline $\begin{array}{l}3.4 \text { Total avul }+\mathrm{Ph} \text { vs total } \\
\text { avul + surg ME }\end{array}$ & 1 & 31 & Risk Ratio (M-H, Random, 95\% CI) & $0.17[0.02,1.25]$ \\
\hline $\begin{array}{l}\text { 3.5 PNA + Ph vs PNA + surg } \\
\text { ME }\end{array}$ & 1 & 71 & Risk Ratio (M-H, Random, 95\% CI) & $1.15[0.75,1.77]$ \\
\hline 4 Postoperative haemorrhage & 2 & & Risk Ratio (M-H, Random, 95\% CI) & Totals not selected \\
\hline $\begin{array}{l}\text { 4.1 PNA + Ph vs wedge + surg } \\
\text { ME }\end{array}$ & 1 & & Risk Ratio (M-H, Random, 95\% CI) & $0.0[0.0,0.0]$ \\
\hline $\begin{array}{l}\text { 4.2 PNA + Ph vs PNA + surg } \\
\text { ME }\end{array}$ & 1 & & Risk Ratio (M-H, Random, 95\% CI) & $0.0[0.0,0.0]$ \\
\hline 5 Postoperative analgesic use & 2 & & Risk Ratio (M-H, Random, 95\% CI) & Totals not selected \\
\hline $\begin{array}{l}5.1 \mathrm{PNA}+\mathrm{Ph} \text { vs wedge + surg } \\
\mathrm{ME}\end{array}$ & 1 & & Risk Ratio (M-H, Random, 95\% CI) & $0.0[0.0,0.0]$ \\
\hline $\begin{array}{l}5.2 \text { PNA + Ph vs PNA + surg } \\
\text { ME }\end{array}$ & 1 & & Risk Ratio (M-H, Random, 95\% CI) & $0.0[0.0,0.0]$ \\
\hline $\begin{array}{l}6 \text { Postoperative pain at } 2 \text { weeks } \\
\text { (VAS) }\end{array}$ & 2 & & Mean Difference (IV, Random, 95\% CI) & Totals not selected \\
\hline $\begin{array}{l}\text { 6.1 PNA + Ph vs PNA + surg } \\
\text { ME }\end{array}$ & 1 & & Mean Difference (IV, Random, 95\% CI) & $0.0[0.0,0.0]$ \\
\hline $\begin{array}{l}\text { 6.2 PNA + Ph vs wedge + surg } \\
\mathrm{ME}\end{array}$ & 1 & & Mean Difference (IV, Random, 95\% CI) & $0.0[0.0,0.0]$ \\
\hline 7 Participant satisfaction & 1 & & Risk Ratio (M-H, Random, 95\% CI) & Totals not selected \\
\hline $\begin{array}{l}\text { 7.1 Total avul + Ph vs total } \\
\text { avul + surg ME }\end{array}$ & 1 & & Risk Ratio (M-H, Random, 95\% CI) & $0.0[0.0,0.0]$ \\
\hline
\end{tabular}

\section{Comparison 4. Surgical procedures: Different types of surg proc}

\begin{tabular}{|c|c|c|c|c|}
\hline Outcome or subgroup title & $\begin{array}{l}\text { No. of } \\
\text { studies }\end{array}$ & $\begin{array}{c}\text { No. of } \\
\text { participants }\end{array}$ & Statistical method & Effect size \\
\hline 1 Recurrence & 2 & & Risk Ratio (M-H, Random, 95\% CI) & Totals not selected \\
\hline 1.1 Nail edge exc vs total avul & 1 & & Risk Ratio (M-H, Random, 95\% CI) & $0.0[0.0,0.0]$ \\
\hline $\begin{array}{l}1.2 \text { Wedge resec vs rad exc of } \\
\text { the nail fold }\end{array}$ & 1 & & Risk Ratio (M-H, Random, 95\% CI) & $0.0[0.0,0.0]$ \\
\hline $\begin{array}{l}1.3 \text { Wedge resec vs rotational } \\
\text { flap technique }\end{array}$ & 1 & & Risk Ratio (M-H, Random, 95\% CI) & $0.0[0.0,0.0]$ \\
\hline $\begin{array}{l}1.4 \text { Rad exc of the nail fold vs } \\
\text { rotational flap technique }\end{array}$ & 1 & & Risk Ratio (M-H, Random, 95\% CI) & $0.0[0.0,0.0]$ \\
\hline 2 Participant satisfaction & 1 & & Risk Ratio (M-H, Random, 95\% CI) & Totals not selected \\
\hline 2.1 Nail edge exc vs total avul & 1 & & Risk Ratio (M-H, Random, 95\% CI) & $0.0[0.0,0.0]$ \\
\hline 3 Postoperative infection & 1 & & Risk Ratio (M-H, Random, 95\% CI) & Totals not selected \\
\hline 3.1 Nail edge exc vs total avul & 1 & & Risk Ratio (M-H, Random, 95\% CI) & $0.0[0.0,0.0]$ \\
\hline
\end{tabular}


Comparison 5. Surgical procedures: Chem abln \& partial avul vs chem abln \& surg

\begin{tabular}{|c|c|c|c|c|}
\hline Outcome or subgroup title & $\begin{array}{l}\text { No. of } \\
\text { studies }\end{array}$ & $\begin{array}{c}\text { No. of } \\
\text { participants }\end{array}$ & Statistical method & Effect size \\
\hline 1 Recurrence & 3 & & Risk Ratio (M-H, Random, 95\% CI) & Totals not selected \\
\hline 1.1 PNA $+\mathrm{Ph}$ vs wedge $+\mathrm{Ph}$ & 1 & & Risk Ratio (M-H, Random, 95\% CI) & $0.0[0.0,0.0]$ \\
\hline 1.2 PNA + Ph vs PNA + sod & 1 & & Risk Ratio (M-H, Random, 95\% CI) & $0.0[0.0,0.0]$ \\
\hline $\begin{array}{l}1.32 \text { min sodium hydr vs } 1 \\
\text { min sodium hydr }\end{array}$ & 1 & & Risk Ratio (M-H, Random, 95\% CI) & $0.0[0.0,0.0]$ \\
\hline 2 Postoperative pain (yes/no) & 1 & & Risk Ratio (M-H, Random, 95\% CI) & Totals not selected \\
\hline 2.1 PNA $+\mathrm{Ph}$ vs wedge $+\mathrm{Ph}$ & 1 & & Risk Ratio (M-H, Random, 95\% CI) & $0.0[0.0,0.0]$ \\
\hline $\begin{array}{l}3 \text { Postoperative pain intensity after } \\
24 \mathrm{~h} \text { duration }\end{array}$ & 1 & & Mean Difference (IV, Random, 95\% CI) & Totals not selected \\
\hline 3.1 PNA $+\mathrm{Ph}$ vs wedge $+\mathrm{Ph}$ & 1 & & Mean Difference (IV, Random, 95\% CI) & $0.0[0.0,0.0]$ \\
\hline
\end{tabular}

Comparison 6. Surgical procedures: Wedge + electroful vs wedge + surg ME

\begin{tabular}{|c|c|c|c|c|}
\hline Outcome or subgroup title & $\begin{array}{l}\text { No. of } \\
\text { studies }\end{array}$ & $\begin{array}{c}\text { No. of } \\
\text { participants }\end{array}$ & Statistical method & Effect size \\
\hline 1 Postoperative pain at 2 weeks & 1 & & Risk Ratio (M-H, Random, 95\% CI) & Totals not selected \\
\hline $\begin{array}{l}\text { 1.1 Wedge + electroful vs } \\
\text { wedge + surg ME }\end{array}$ & 1 & & Risk Ratio (M-H, Random, 95\% CI) & $0.0[0.0,0.0]$ \\
\hline $\begin{array}{l}2 \text { Postoperative haemorrhage at } 2 \\
\text { weeks }\end{array}$ & 1 & & Risk Ratio (M-H, Random, 95\% CI) & Totals not selected \\
\hline $\begin{array}{l}2.1 \text { Wedge + electroful vs } \\
\text { wedge + surg ME }\end{array}$ & 1 & & Risk Ratio (M-H, Random, 95\% CI) & $0.0[0.0,0.0]$ \\
\hline
\end{tabular}

\section{Comparison 7. Postoperative procedures}

\begin{tabular}{|c|c|c|c|c|}
\hline Outcome or subgroup title & $\begin{array}{l}\text { No. of } \\
\text { studies }\end{array}$ & $\begin{array}{c}\text { No. of } \\
\text { participants }\end{array}$ & Statistical method & Effect size \\
\hline 1 Recurrence & 1 & & Risk Ratio (M-H, Random, 95\% CI) & Totals not selected \\
\hline $\begin{array}{l}\text { 1.1 PNA + surg ME vs PNA + } \\
\mathrm{Ph}\end{array}$ & 1 & & Risk Ratio (M-H, Random, 95\% CI) & $0.0[0.0,0.0]$ \\
\hline 2 Postoperative infection & 3 & & Risk Ratio (M-H, Random, 95\% CI) & Totals not selected \\
\hline $\begin{array}{l}\text { 2.1 PNA + surg } \mathrm{ME}+\mathrm{AB} \text { vs } \\
\mathrm{PNA}+\mathrm{Ph}+\mathrm{AB}\end{array}$ & 1 & & Risk Ratio (M-H, Random, 95\% CI) & $0.0[0.0,0.0]$ \\
\hline $\begin{array}{l}2.2 \text { Povidone-iodine with } \\
\text { paraff gauze vs hydrogel with } \\
\text { paraff gauze }\end{array}$ & 1 & & Risk Ratio (M-H, Random, 95\% CI) & $0.0[0.0,0.0]$ \\
\hline $\begin{array}{l}2.3 \text { Povidone-iodine with } \\
\text { paraff gauze vs paraff gauze } \\
\text { only }\end{array}$ & 1 & & Risk Ratio (M-H, Random, 95\% CI) & $0.0[0.0,0.0]$ \\
\hline
\end{tabular}




\begin{tabular}{|c|c|c|c|}
\hline $\begin{array}{l}2.4 \text { Hydrogel with paraff } \\
\text { gauze vs paraff gauze only }\end{array}$ & 1 & Risk Ratio (M-H, Random, 95\% CI) & $0.0[0.0,0.0]$ \\
\hline $\begin{array}{l}\text { 2.5 Manuka honey dressing vs } \\
\text { paraff-impregn tulle gras }\end{array}$ & 1 & Risk Ratio (M-H, Random, 95\% CI) & $0.0[0.0,0.0]$ \\
\hline Postoperative pain (VAS) & 1 & Mean Difference (IV, Random, 95\% CI) & Totals not selected \\
\hline $\begin{array}{l}\text { 3.1 Manuka honey dressing vs } \\
\text { paraff-impregn tulle gras }\end{array}$ & 1 & Mean Difference (IV, Random, 95\% CI) & $0.0[0.0,0.0]$ \\
\hline Healing time (days) & 2 & Mean Difference (IV, Random, 95\% CI) & Totals not selected \\
\hline $\begin{array}{l}\text { 4.1 Povidone-iodine with } \\
\text { paraff gauze vs hydrogel with } \\
\text { paraff gauze }\end{array}$ & 1 & Mean Difference (IV, Random, 95\% CI) & $0.0[0.0,0.0]$ \\
\hline $\begin{array}{l}4.2 \text { Povidone-iodine with } \\
\text { paraff gauze vs paraff gauze } \\
\text { only }\end{array}$ & 1 & Mean Difference (IV, Random, 95\% CI) & $0.0[0.0,0.0]$ \\
\hline $\begin{array}{l}4.3 \text { Hydrogel with paraff } \\
\text { gauze vs paraff gauze only }\end{array}$ & 1 & Mean Difference (IV, Random, 95\% CI) & $0.0[0.0,0.0]$ \\
\hline $\begin{array}{l}\text { 4.4 Manuka honey dressing vs } \\
\text { paraff-impregn tulle gras }\end{array}$ & 1 & Mean Difference (IV, Random, 95\% CI) & $0.0[0.0,0.0]$ \\
\hline
\end{tabular}

Comparison 8. Surgery plus postoperative treatment vs surgery

\begin{tabular}{|c|c|c|c|c|}
\hline Outcome or subgroup title & $\begin{array}{l}\text { No. of } \\
\text { studies }\end{array}$ & $\begin{array}{c}\text { No. of } \\
\text { participants }\end{array}$ & Statistical method & Effect size \\
\hline 1 Recurrence & 1 & & Risk Ratio (M-H, Random, 95\% CI) & Totals not selected \\
\hline $\begin{array}{l}\text { 1.1 PNA + surg ME + AB vs } \\
\text { PNA + surg ME }\end{array}$ & 1 & & Risk Ratio (M-H, Random, 95\% CI) & $0.0[0.0,0.0]$ \\
\hline 2 Postoperative infection & 1 & & Risk Ratio (M-H, Random, 95\% CI) & Totals not selected \\
\hline $\begin{array}{l}\text { 2.1 PNA + surg ME + AB vs } \\
\text { PNA + surg ME }\end{array}$ & 1 & & Risk Ratio (M-H, Random, 95\% CI) & $0.0[0.0,0.0]$ \\
\hline
\end{tabular}

Comparison 9. Surgery plus postoperative treatment vs phenol

\begin{tabular}{|c|c|c|c|c|}
\hline Outcome or subgroup title & $\begin{array}{l}\text { No. of } \\
\text { studies }\end{array}$ & $\begin{array}{c}\text { No. of } \\
\text { participants }\end{array}$ & Statistical method & Effect size \\
\hline 1 Recurrence & 1 & & Risk Ratio (M-H, Random, 95\% CI) & Totals not selected \\
\hline $\begin{array}{l}\text { 1.1 PNA + surg } \mathrm{ME}+\mathrm{AB} \text { vs } \\
\mathrm{PNA}+\mathrm{Ph}\end{array}$ & 1 & & Risk Ratio (M-H, Random, 95\% CI) & $0.0[0.0,0.0]$ \\
\hline 2 Postoperative infection & 1 & & Risk Ratio (M-H, Random, 95\% CI) & Totals not selected \\
\hline $\begin{array}{l}\text { 2.1 PNA + surg } \mathrm{ME}+\mathrm{AB} \text { vs } \\
\mathrm{PNA}+\mathrm{Ph}\end{array}$ & 1 & & Risk Ratio (M-H, Random, 95\% CI) & $0.0[0.0,0.0]$ \\
\hline
\end{tabular}




\begin{tabular}{|c|c|c|c|c|}
\hline Outcome or subgroup title & $\begin{array}{l}\text { No. of } \\
\text { studies }\end{array}$ & $\begin{array}{c}\text { No. of } \\
\text { participants }\end{array}$ & Statistical method & Effect size \\
\hline 1 Recurrence & 1 & & Risk Ratio (M-H, Random, 95\% CI) & Totals not selected \\
\hline $\begin{array}{l}\text { 1.1 PNA + Ph + AB vs PNA + } \\
\mathrm{Ph}\end{array}$ & 1 & & Risk Ratio (M-H, Random, 95\% CI) & $0.0[0.0,0.0]$ \\
\hline 2 Postoperative infection & 2 & & Risk Ratio (M-H, Random, 95\% CI) & Totals not selected \\
\hline $\begin{array}{l}2.1 \mathrm{PNA}+\mathrm{Ph}+1 \mathrm{wk} \mathrm{AB} \text { after } \\
\text { vs PNA }+\mathrm{Ph}\end{array}$ & 1 & & Risk Ratio (M-H, Random, 95\% CI) & $0.0[0.0,0.0]$ \\
\hline $\begin{array}{l}2.2 \mathrm{PNA}+\mathrm{Ph}+1 \mathrm{wk} \mathrm{AB} \text { after } \\
\text { vs PNA + Ph }\end{array}$ & 1 & & Risk Ratio (M-H, Random, 95\% CI) & $0.0[0.0,0.0]$ \\
\hline 3 Healing time (weeks) & 1 & & Mean Difference (IV, Random, 95\% CI) & Totals not selected \\
\hline $\begin{array}{l}\text { 3.1 PNA }+\mathrm{Ph}+1 \mathrm{wk} A B \\
\text { afterwards vs PNA }+\mathrm{Ph}\end{array}$ & 1 & & Mean Difference (IV, Random, 95\% CI) & $0.0[0.0,0.0]$ \\
\hline
\end{tabular}

Comparison 11. Phenol plus postoperative treatment vs surgery

\begin{tabular}{|c|c|c|c|c|}
\hline Outcome or subgroup title & $\begin{array}{l}\text { No. of } \\
\text { studies }\end{array}$ & $\begin{array}{c}\text { No. of } \\
\text { participants }\end{array}$ & Statistical method & Effect size \\
\hline 1 Recurrence & 1 & & Risk Ratio (M-H, Random, 95\% CI) & Totals not selected \\
\hline $\begin{array}{l}\text { 1.1 PNA + Ph + AB vs PNA + } \\
\text { surg ME }\end{array}$ & 1 & & Risk Ratio (M-H, Random, 95\% CI) & $0.0[0.0,0.0]$ \\
\hline 2 Postoperative infection & 1 & & Risk Ratio (M-H, Random, 95\% CI) & Totals not selected \\
\hline $\begin{array}{l}\text { 2.1 PNA + Ph + AB vs PNA + } \\
\text { surg ME }\end{array}$ & 1 & & Risk Ratio (M-H, Random, 95\% CI) & $0.0[0.0,0.0]$ \\
\hline
\end{tabular}

Comparison 12. Preoperative treatment vs postoperative treatment

\begin{tabular}{|c|c|c|c|c|}
\hline Outcome or subgroup title & $\begin{array}{l}\text { No. of } \\
\text { studies }\end{array}$ & $\begin{array}{c}\text { No. of } \\
\text { participants }\end{array}$ & Statistical method & Effect size \\
\hline 1 Healing time (weeks) & 1 & & Mean Difference (IV, Random, 95\% CI) & Totals not selected \\
\hline $\begin{array}{l}\text { 1.1 PNA }+\mathrm{Ph}+1 \mathrm{wk} \mathrm{AB} \\
\text { advance vs PNA }+\mathrm{Ph}+1 \mathrm{wk} \\
\mathrm{AB} \text { afterwards }\end{array}$ & 1 & & Mean Difference (IV, Random, 95\% CI) & $0.0[0.0,0.0]$ \\
\hline
\end{tabular}




\begin{tabular}{|c|c|c|c|c|}
\hline Outcome or subgroup title & $\begin{array}{l}\text { No. of } \\
\text { studies }\end{array}$ & $\begin{array}{c}\text { No. of } \\
\text { participants }\end{array}$ & Statistical method & Effect size \\
\hline 1 Postoperative infection & 1 & & Risk Ratio (M-H, Random, 95\% CI) & Totals not selected \\
\hline $\begin{array}{l}1.1 \mathrm{PNA}+\mathrm{Ph}+1 \mathrm{wk} \mathrm{AB} \\
\text { advance vs PNA }+\mathrm{Ph}\end{array}$ & 1 & & Risk Ratio (M-H, Random, 95\% CI) & $0.0[0.0,0.0]$ \\
\hline 2 Healing time (weeks) & 1 & & Mean Difference (IV, Random, 95\% CI) & Totals not selected \\
\hline $\begin{array}{l}2.1 \mathrm{PNA}+\mathrm{Ph}+1 \mathrm{wk} \mathrm{AB} \\
\text { advance vs PNA }+\mathrm{Ph}\end{array}$ & 1 & & Mean Difference (IV, Random, 95\% CI) & $0.0[0.0,0.0]$ \\
\hline
\end{tabular}

\section{Analysis I.I. Comparison I Non-surgical procedures, Outcome I Recurrence.}

Review: Interventions for ingrowing toenails

Comparison: I Non-surgical procedures

Outcome: I Recurrence

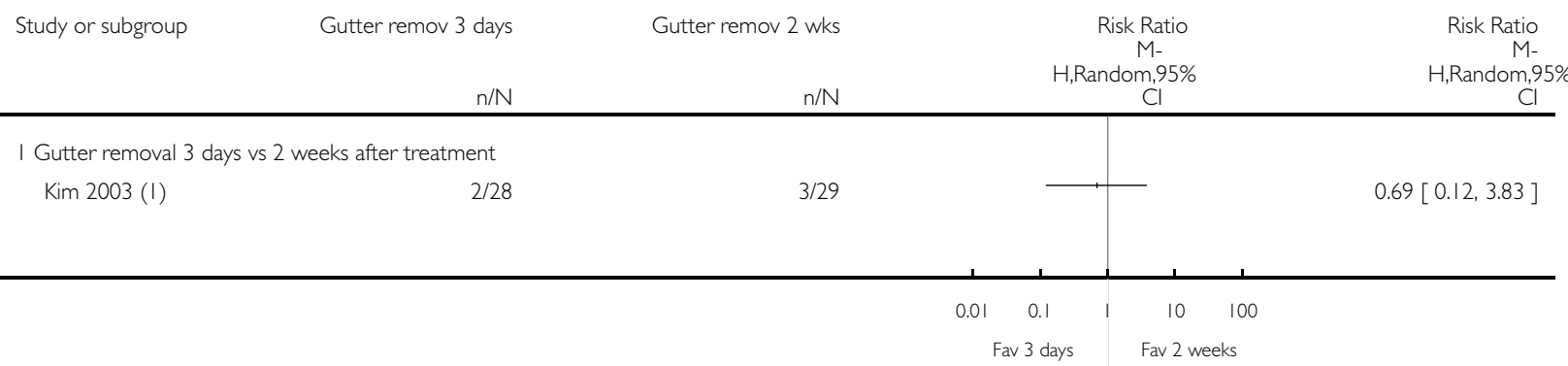

(I) $n$ = number of patients 


\section{Analysis 2.I. Comparison 2 Non-surgical vs surgical procedures, Outcome I Recurrence.}

Review: Interventions for ingrowing toenails

Comparison: 2 Non-surgical vs surgical procedures

Outcome: I Recurrence

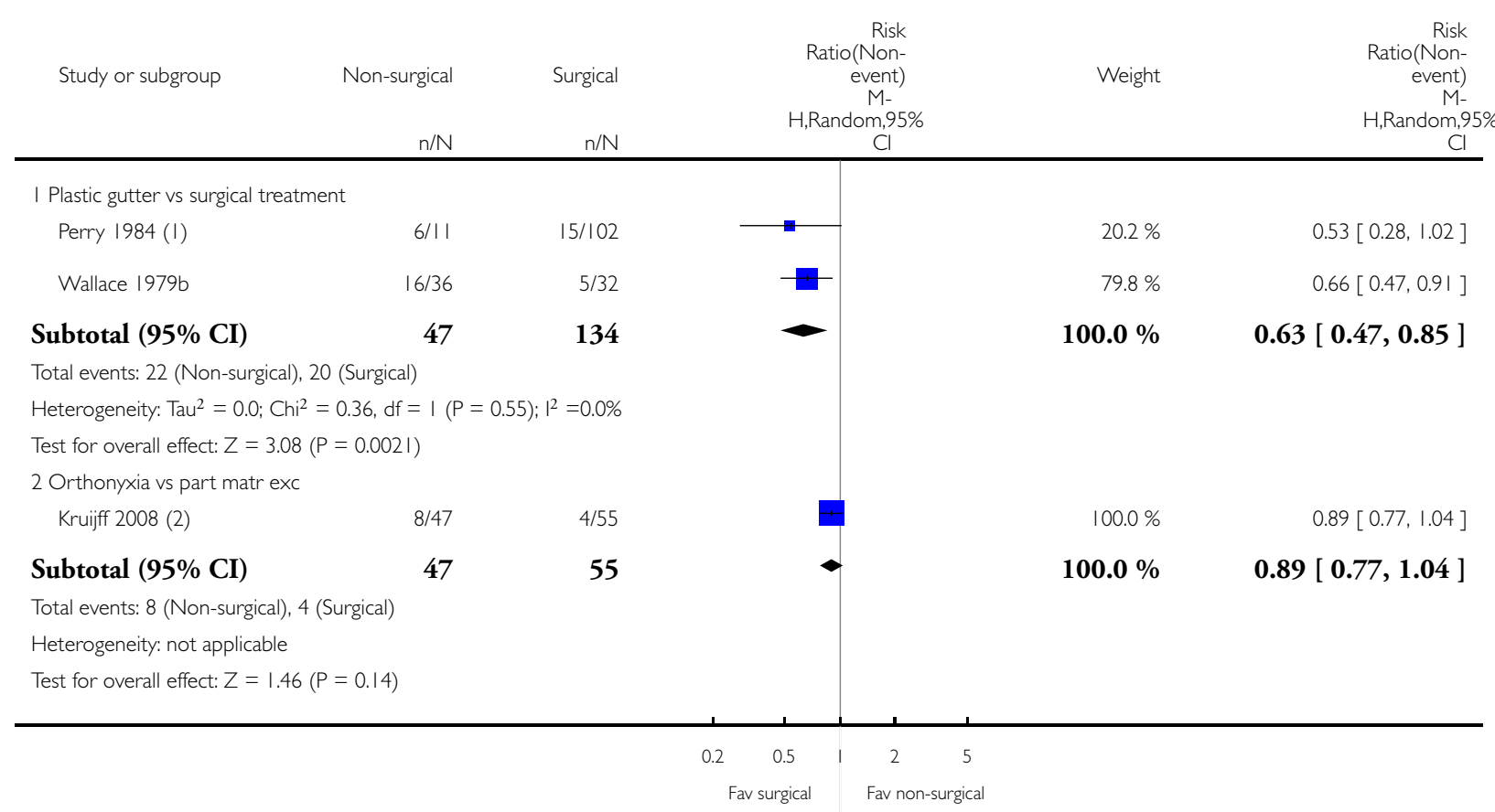

(I) $n=$ number of nail edges

(2) $n=$ number of toenails 
Analysis 3.I. Comparison 3 Surgical procedures: Chem abln \& surg vs surg proc, Outcome I Recurrence. Review: Interventions for ingrowing toenails

Comparison: 3 Surgical procedures: Chem abln \% surg vs surg proc

Outcome: | Recurrence

Study or subgroup

Chem abl+surg

Surg

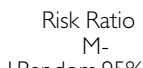

Risk Ratio

H,Random,95\%

$\mathrm{H}$,Random,95\%

I PNA + Ph vs wedge + surg ME

Issa 1988 (I)

$\mathrm{n} / \mathrm{N}$

$\mathrm{n} / \mathrm{N}$

\begin{tabular}{l|l}
-1 \\
-
\end{tabular}

Leahy 1990 (2)

$4 / 53$

$7 / 55$

$11 / 39$

$12 / 46$

Morkane 1984 (3)

$4 / 54$

16/53

van der Ham 1990 (4)

$12 / 125$

$20 / 124$

Varma $1983(5)$

$7 / 28$

$9 / 35$

$2 \mathrm{PNA}+\mathrm{Ph}$ vs nail edge exc

Greig 199la (6)

$6 / 67$

$4 \mid / 56$

3 PNA + Ph vs total avul

Greig 1991a (7)

$6 / 67$

Sykes 1988c (8)

15/307

$59 / 81$

$20 / 38$

$4 \mathrm{Ph}+$ total avul vs total avul + surg ME

Anderson 1990 (9)

$6 / 14$

$10 / 17$

5 PNA + Ph vs PNA + Surg ME

Bos 2006 ( I0)

Gerritsma-Bleeker 2002 (I I)

$7 / 29$

$16 / 38$

PNA + sod vs total avul

Shaath 2005 (12)

$7 / 45$

$7 / 34$

PNA + ph vs PNA

Bos 2006

$8 / 58$

$23 / 38$

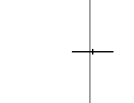

$1.08[0.54,2.17]$

$0.25[0.09,0.69]$

$0.60[0.30,1.16]$

$0.97[0.41,2.28]$

$0.12[0.06,0.27]$

$0.12[0.06,0.27]$

$0.09[0.05,0.17]$

$0.73[0.35,1.50]$

$0.50[0.24,1.07]$

I. $17[0.47,2.95]$

$0.26[0.12,0.53]$

24/59

$0.34[0.17,0.69]$

(I) $n=$ number of nails

(2) $n=$ number of nail edges

(3) $n=$ number of toes

(4) $n=$ number of participants

(5) $n=$ number of participants

(6) $n=$ number of nails

(7) $n=$ number of nail edges

(8) $n=$ number of participants

(9) $n=$ number of participants

(I0) $n=$ number of participants

(I I) $n=$ number of toenails

(I2) n= number of participants 


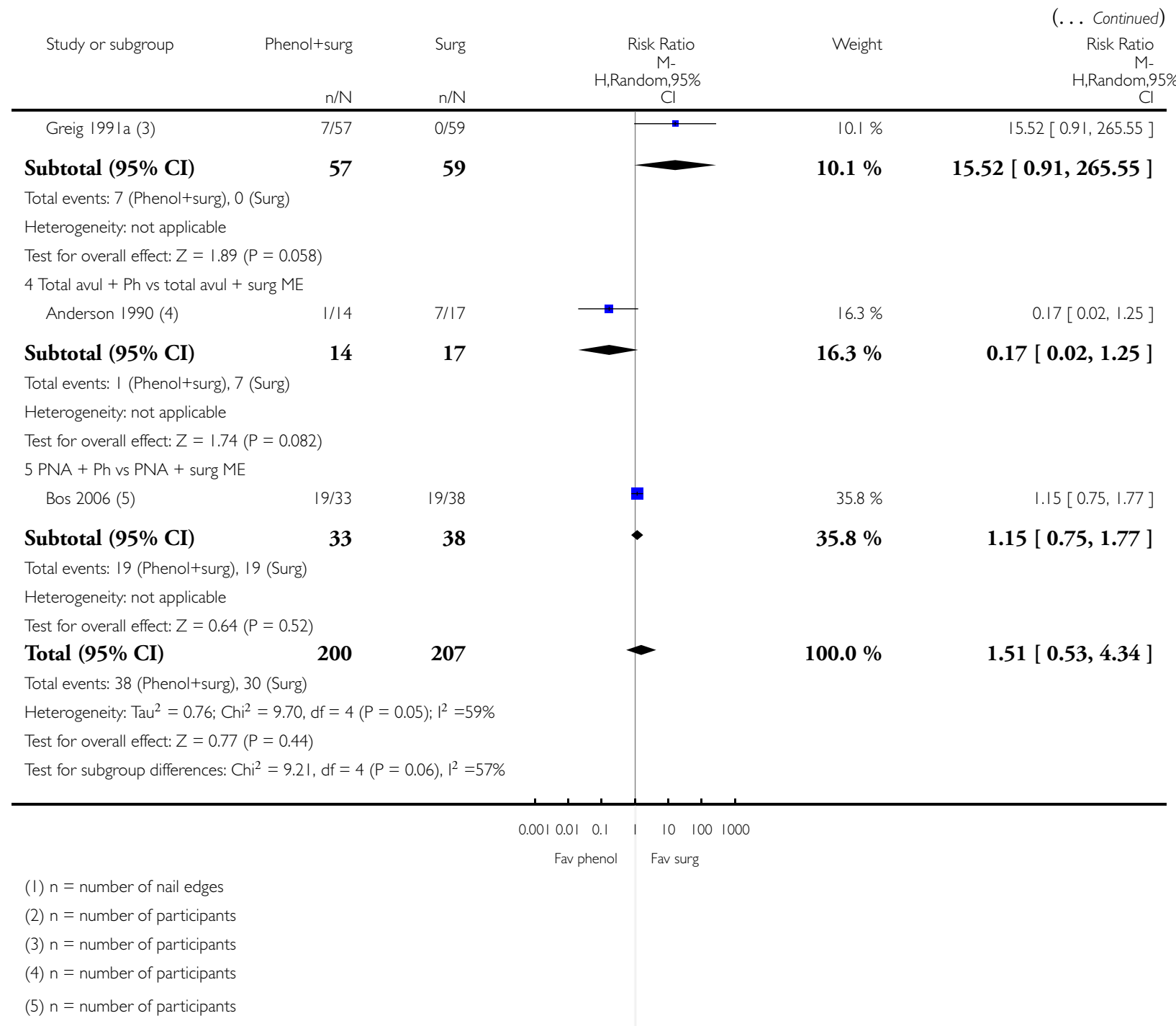


Analysis 3.4. Comparison 3 Surgical procedures: Chem abln \& surg vs surg proc, Outcome 4 Postoperative haemorrhage.

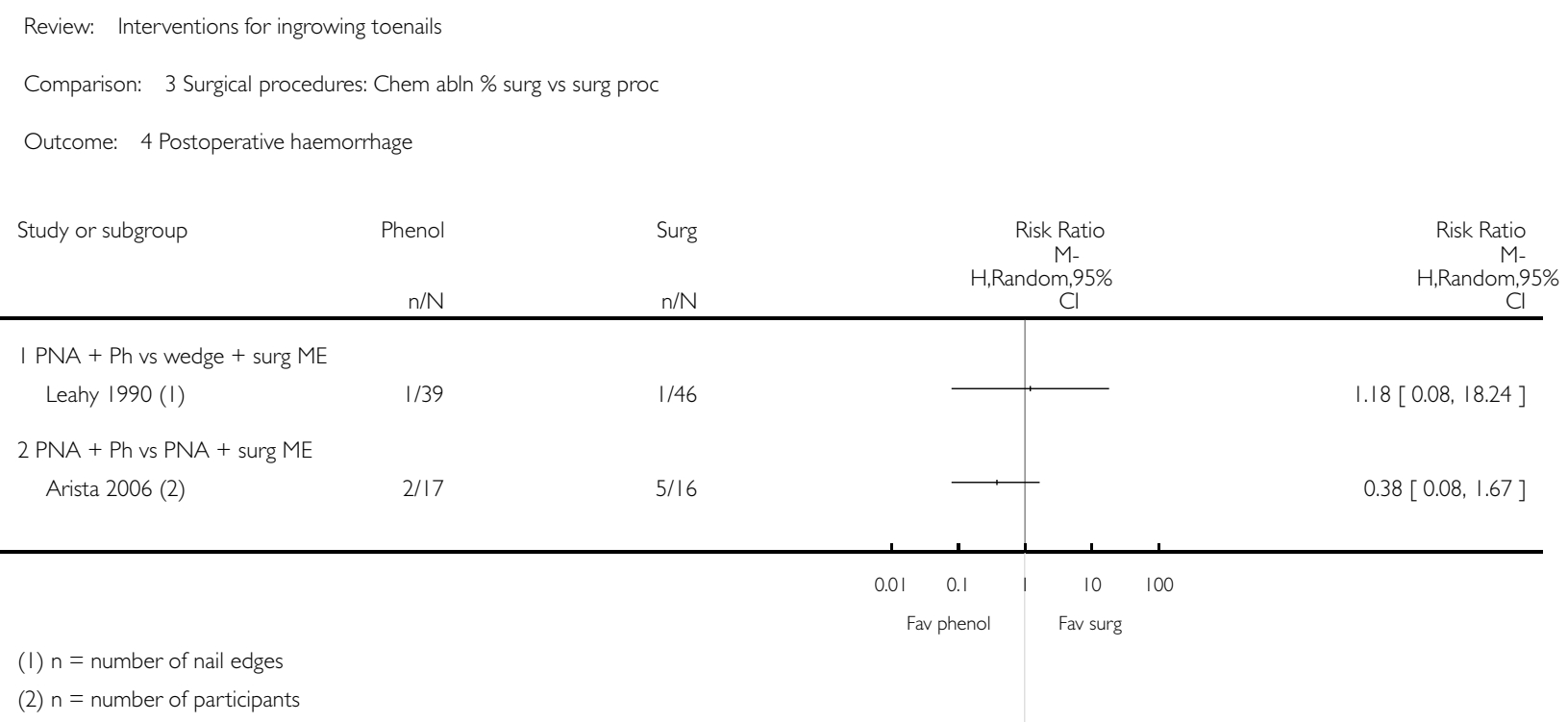

Analysis 3.5. Comparison 3 Surgical procedures: Chem abln \& surg vs surg proc, Outcome 5 Postoperative analgesic use.

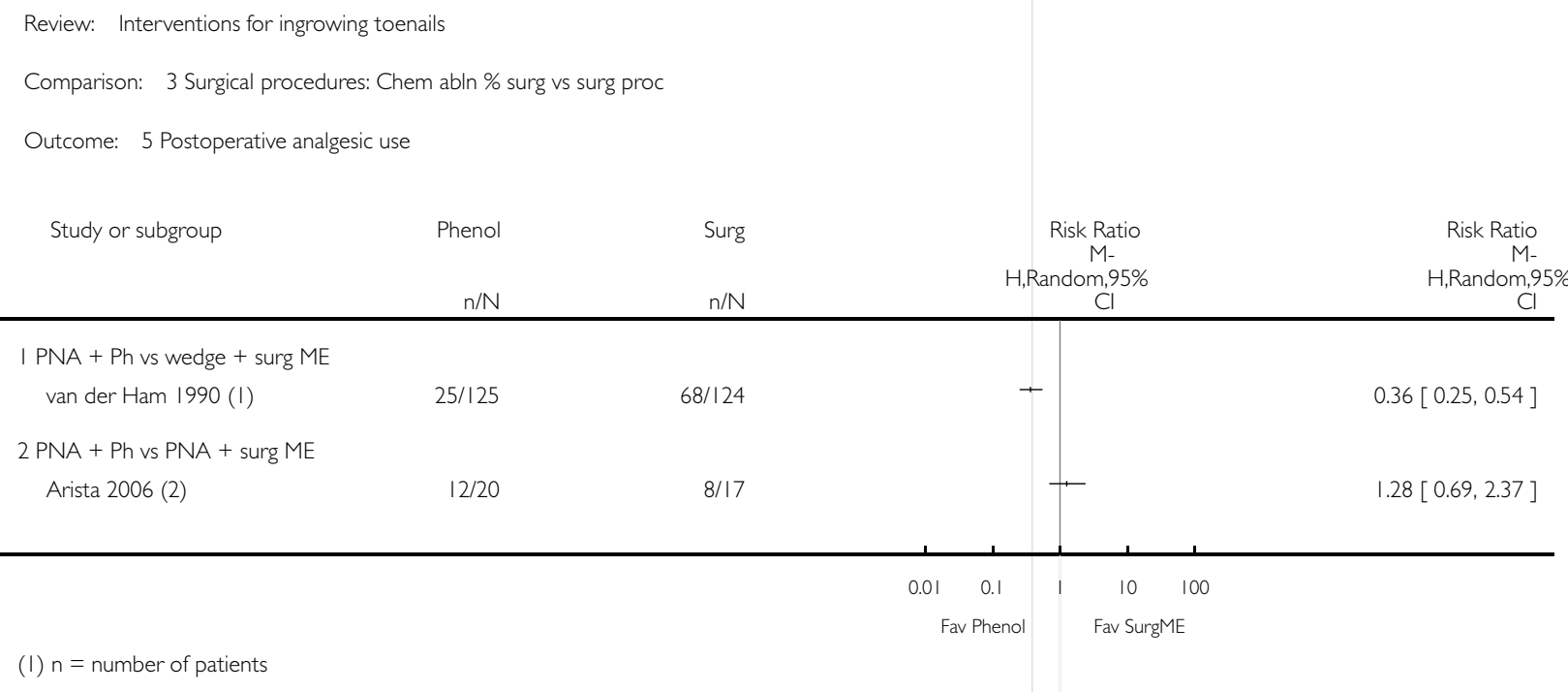

(2) $n=$ number of toenails 
Analysis 3.6. Comparison 3 Surgical procedures: Chem abln \& surg vs surg proc, Outcome 6 Postoperative pain at 2 weeks (VAS).

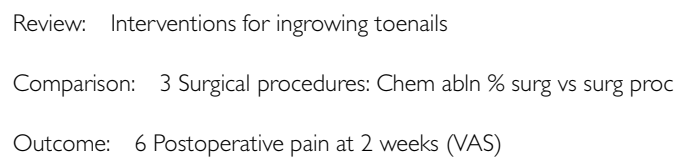

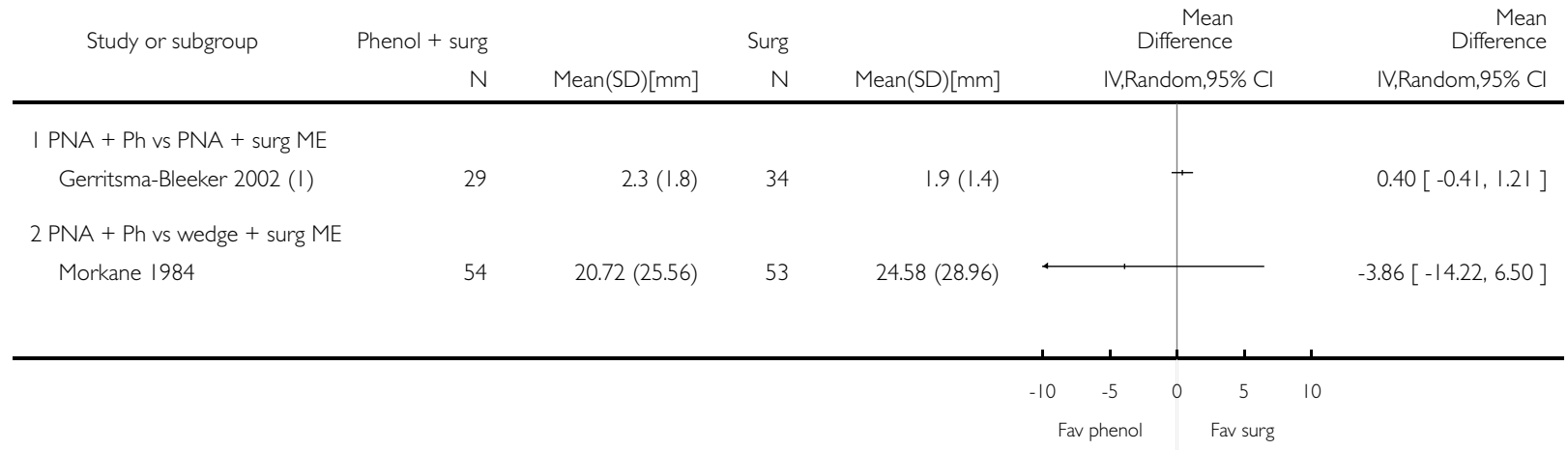

(I) $n=$ number of toenails

Analysis 3.7. Comparison 3 Surgical procedures: Chem abln \& surg vs surg proc, Outcome 7 Participant satisfaction.

Review: Interventions for ingrowing toenails

Comparison: 3 Surgical procedures: Chem abln \% surg vs surg proc

Outcome: 7 Participant satisfaction

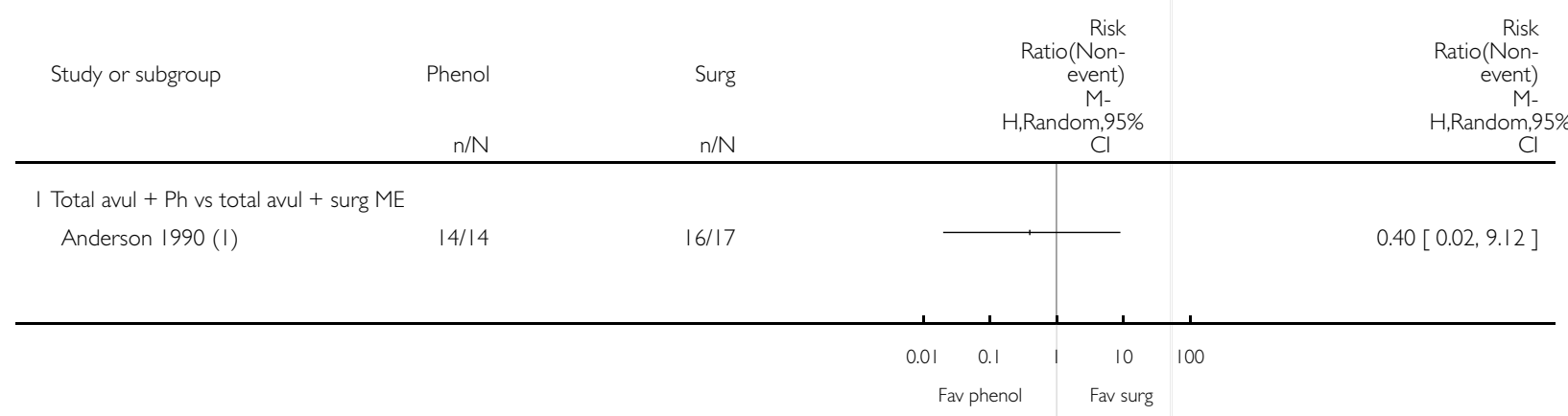

(I) $n$ = number of patients 
Analysis 4.I. Comparison 4 Surgical procedures: Different types of surg proc, Outcome I Recurrence.

Review: Interventions for ingrowing toenails

Comparison: 4 Surgical procedures: Different types of surg proc

Outcome: | Recurrence

SurgProc A

SurgProc B

Risk Ratio

H.Random- $95 \%$

Risk Ratio

H,Random, $95 \%$

\begin{tabular}{|c|c|c|c|c|}
\hline & $\mathrm{n} / \mathrm{N}$ & $\mathrm{n} / \mathrm{N}$ & $\begin{array}{c}\mathrm{H}, \mathrm{Random}, 95 \% \\
\mathrm{Cl}\end{array}$ & $\begin{array}{r}\mathrm{H} \text {,Random, } \\
\mathrm{Cl}\end{array}$ \\
\hline \multicolumn{5}{|c|}{ I Nail edge exc vs total avul } \\
\hline Greig 1991a (I) & $41 / 56$ & $59 / 81$ & + & $1.01[0.82,1.24]$ \\
\hline \multicolumn{5}{|c|}{2 Wedge resec vs rad exc of the nail fold } \\
\hline Perry 1984 (2) & $2 / 32$ & $2 / 36$ & & $1.13[0.17,7.53]$ \\
\hline \multicolumn{5}{|c|}{3 Wedge resec vs rotational flap technique } \\
\hline Perry 1984 (3) & $2 / 32$ & $11 / 34$ & $\overline{-}$ & $0.19[0.05,0.80]$ \\
\hline \multicolumn{5}{|c|}{4 Rad exc of the nail fold vs rotational flap technique } \\
\hline Perry 1984 (4) & $2 / 36$ & $1 \mid / 34$ & - & $0.17[0.04,0.72]$ \\
\hline
\end{tabular}

0.020 .1

$10 \quad 50$

(I) $n=$ number of nails

Fav SurgProc A Fav SurgProc B

(2) $n=$ number of nails

(3) $n=$ number of nails

(4) $n=$ number of nails

\section{Analysis 4.2. Comparison 4 Surgical procedures: Different types of surg proc, Outcome 2 Participant} satisfaction.

Review: Interventions for ingrowing toenails

Comparison: 4 Surgical procedures: Different types of surg proc

Outcome: 2 Participant satisfaction

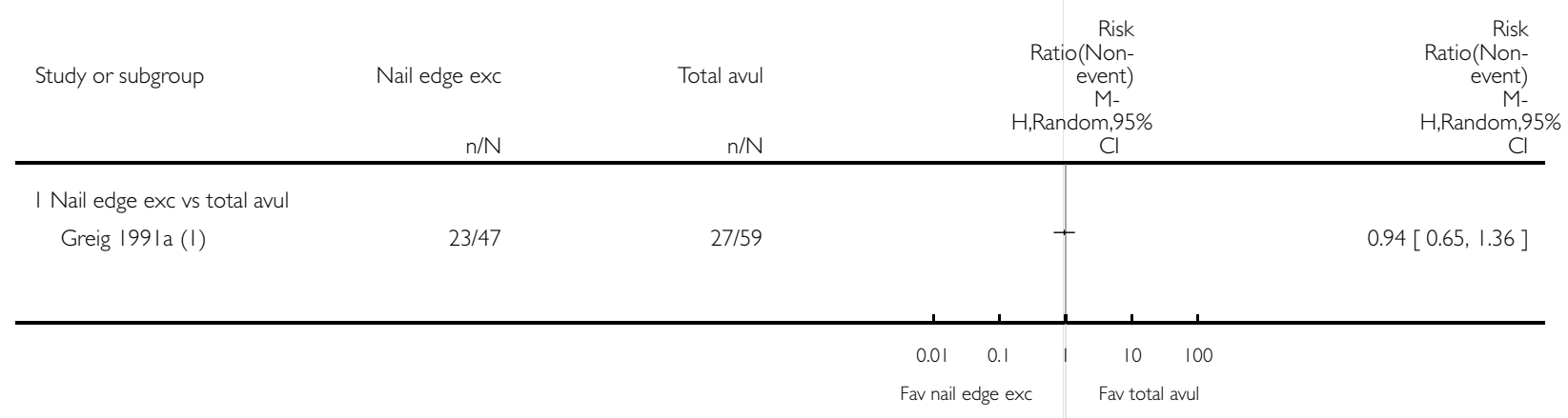

(I) $n=$ patients

Interventions for ingrowing toenails (Review)

Copyright (c) 2012 The Cochrane Collaboration. Published by John Wiley \& Sons, Ltd. 


\section{Analysis 4.3. Comparison 4 Surgical procedures: Different types of surg proc, Outcome 3 Postoperative}

infection.

Review: Interventions for ingrowing toenails

Comparison: 4 Surgical procedures: Different types of surg proc

Outcome: 3 Postoperative infection

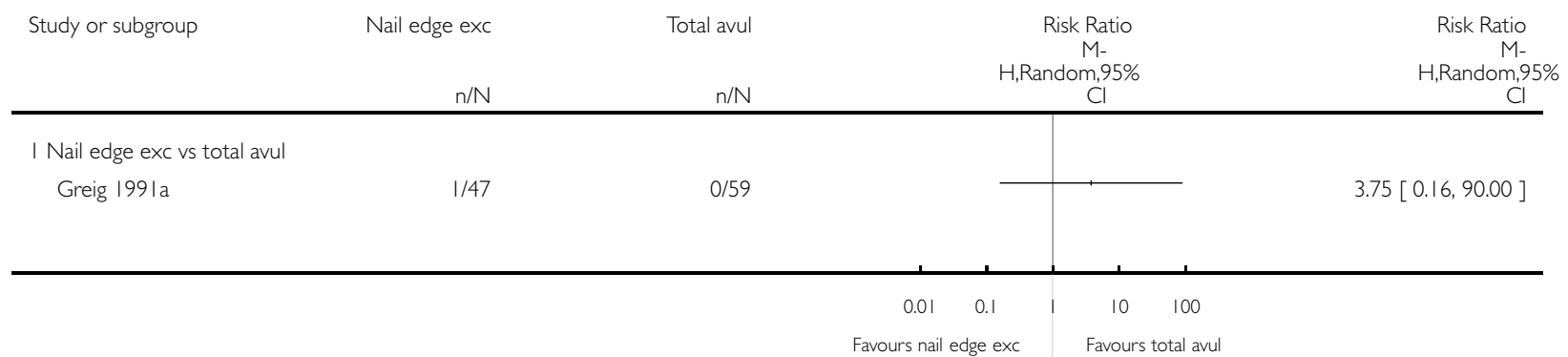

Analysis 5.I. Comparison 5 Surgical procedures: Chem abln \& partial avul vs chem abln \& surg, Outcome I Recurrence.

Review: Interventions for ingrowing toenails

Comparison: 5 Surgical procedures: Chem abln \% partial avul vs chem abln \% surg

Outcome: I Recurrence

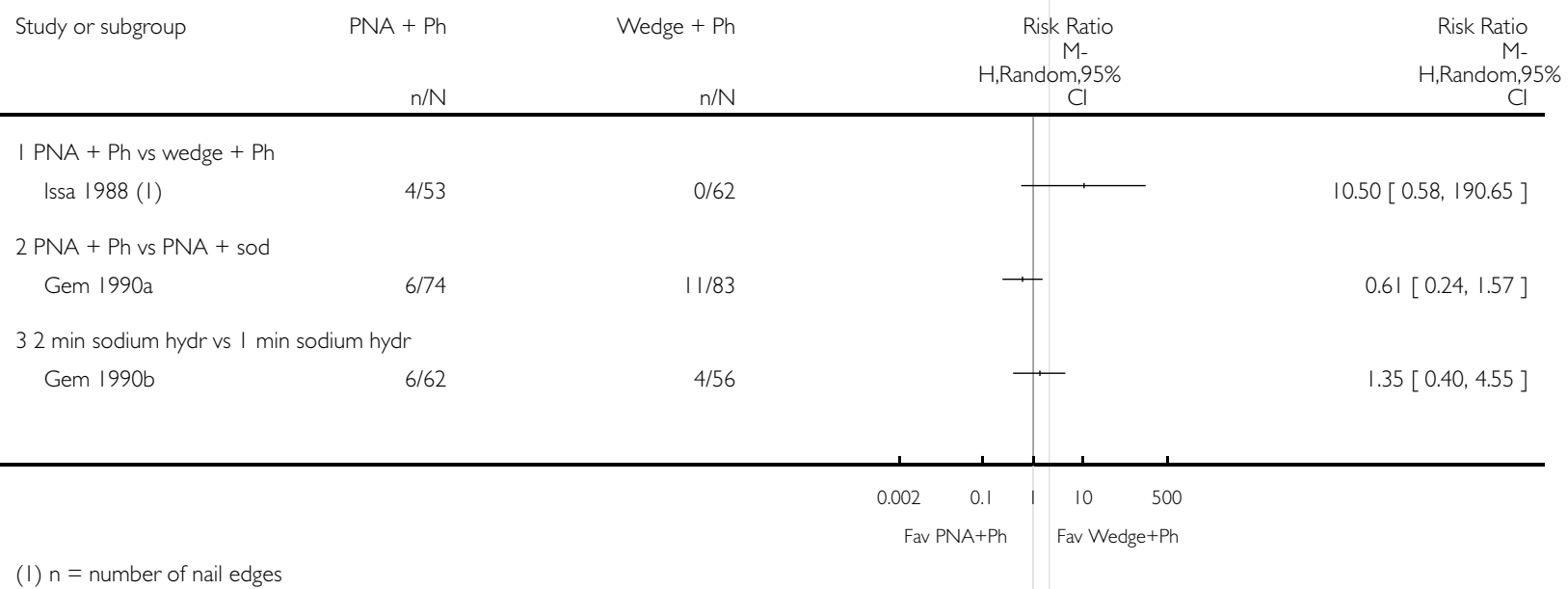

Copyright (C) 2012 The Cochrane Collaboration. Published by John Wiley \& Sons, Ltd. 
Analysis 5.2. Comparison 5 Surgical procedures: Chem abln \& partial avul vs chem abln \& surg, Outcome 2 Postoperative pain (yes/no).

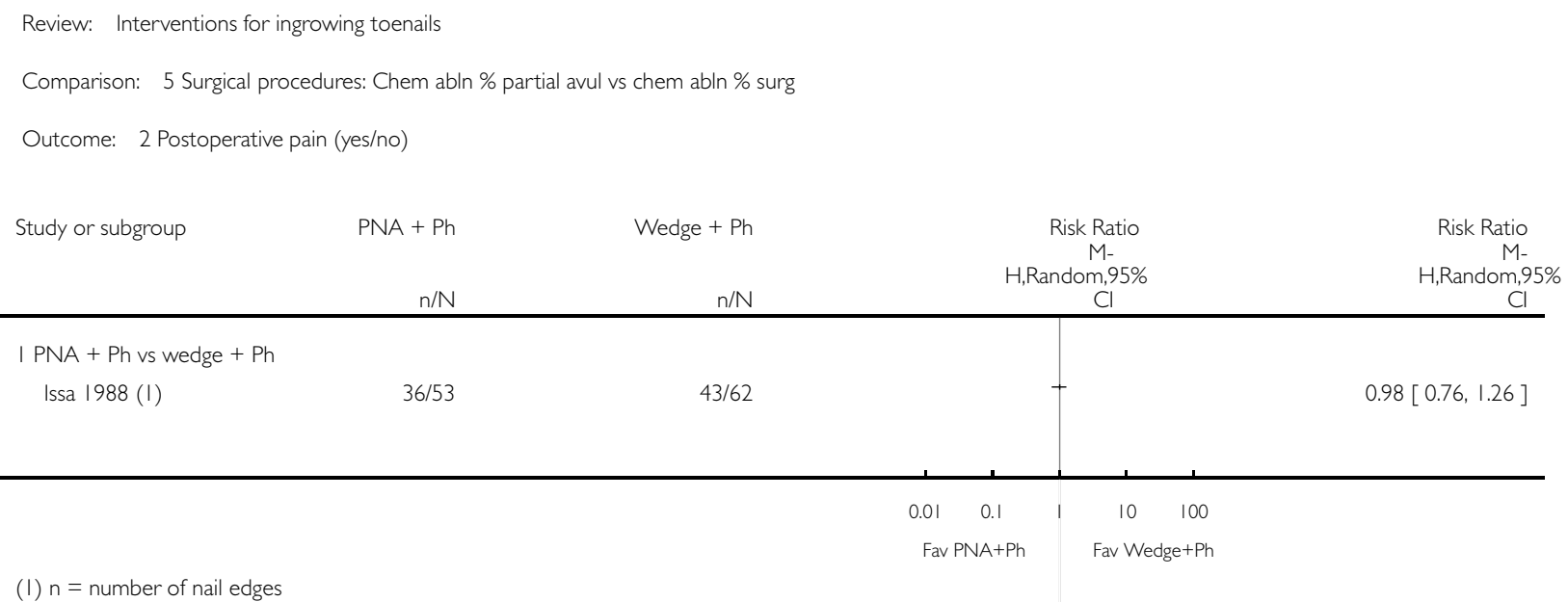

Analysis 5.3. Comparison 5 Surgical procedures: Chem abln \& partial avul vs chem abln \& surg, Outcome 3 Postoperative pain intensity after $24 \mathrm{~h}$ duration.

Review: Interventions for ingrowing toenails

Comparison: 5 Surgical procedures: Chem abln \% partial avul vs chem abln \% surg

Outcome: 3 Postoperative pain intensity after $24 \mathrm{~h}$ duration

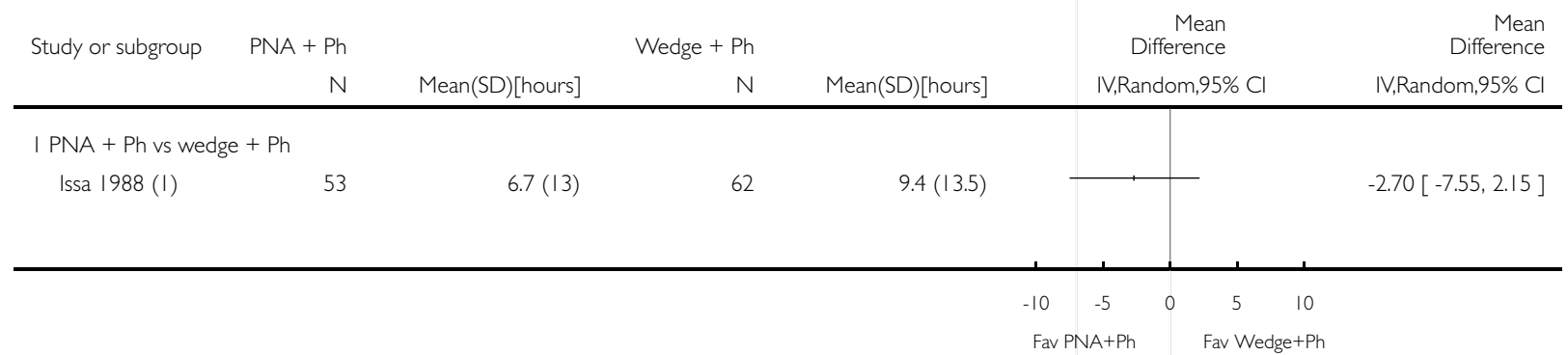

(I) $n$ = number of nail edges 
Analysis 6.1. Comparison 6 Surgical procedures: Wedge + electroful vs wedge + surg ME, Outcome I Postoperative pain at 2 weeks.

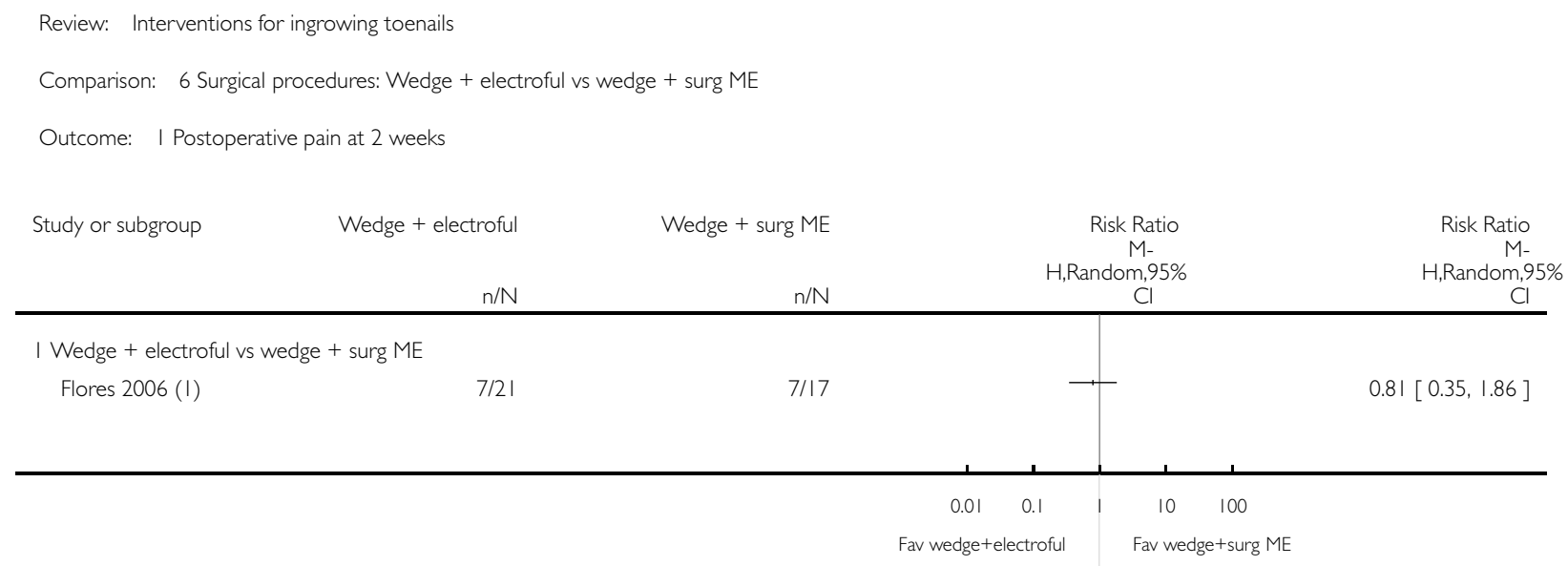

Analysis 6.2. Comparison 6 Surgical procedures: Wedge + electroful vs wedge + surg ME, Outcome 2 Postoperative haemorrhage at 2 weeks.

Review: Interventions for ingrowing toenails

Comparison: 6 Surgical procedures: Wedge + electroful vs wedge + surg ME

Outcome: 2 Postoperative haemorrhage at 2 weeks

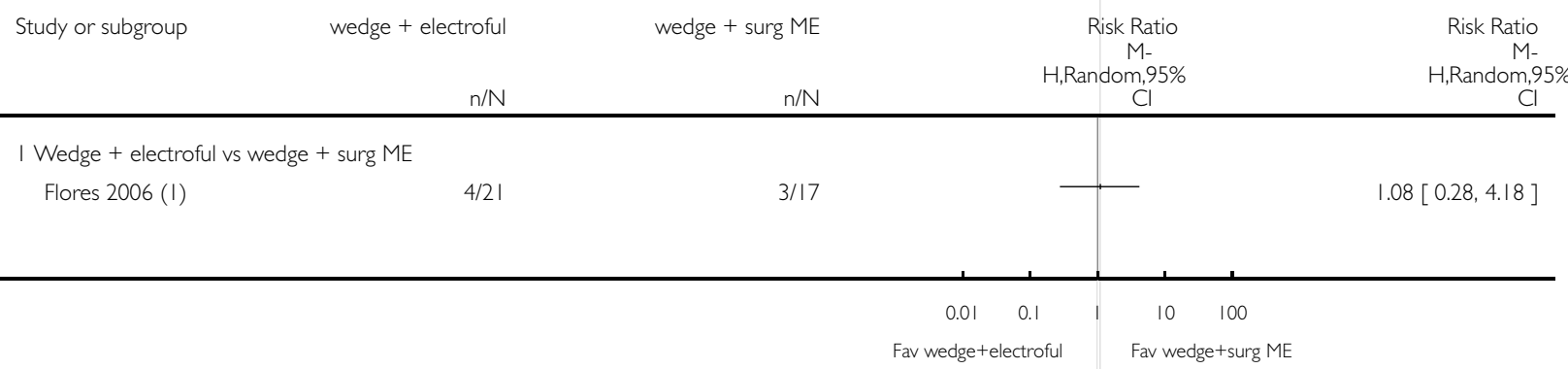

( $\mathrm{n}$ = number of nail edges 


\section{Analysis 7.I. Comparison 7 Postoperative procedures, Outcome I Recurrence.}

Review: Interventions for ingrowing toenails

Comparison: 7 Postoperative procedures

Outcome: I Recurrence

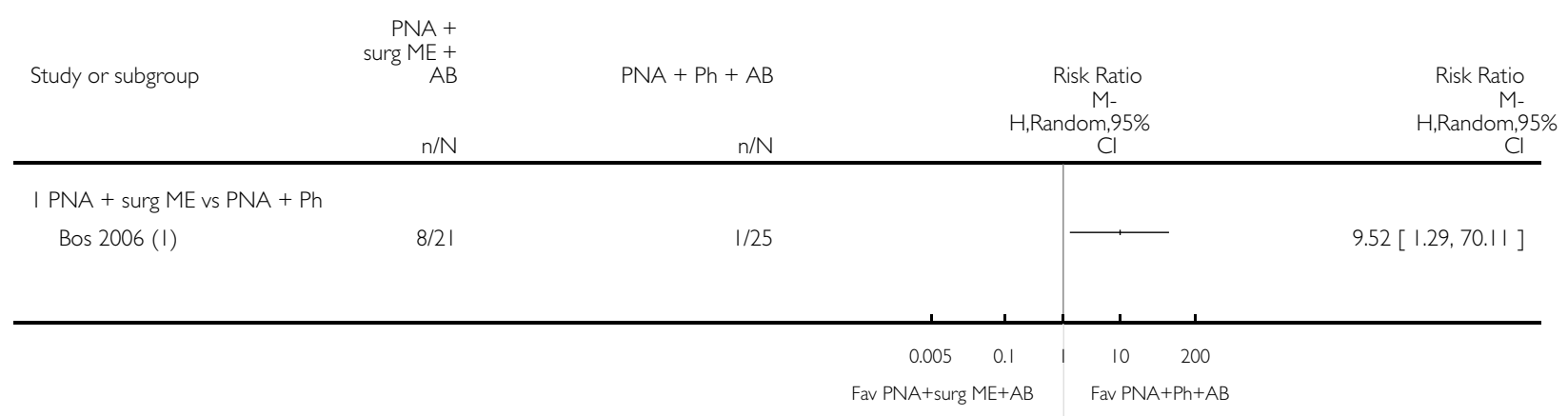

( 1$) \mathrm{n}=$ number of patients

Analysis 7.2. Comparison 7 Postoperative procedures, Outcome 2 Postoperative infection.

Review: Interventions for ingrowing toenails

Comparison: 7 Postoperative procedures

Outcome: 2 Postoperative infection

\begin{tabular}{|c|c|c|c|c|}
\hline Study or subgroup & Intervention A & $\begin{array}{r}\text { Intervention B } \\
n / N\end{array}$ & $\begin{array}{c}\text { Risk Ratio } \\
\text { M- } \\
\text { H,Random,95\% } \\
\text { Cl }\end{array}$ & $\begin{array}{c}\text { Risk Ratio } \\
\text { M- } \\
\text { H,Random,95\% } \\
\text { Cl }\end{array}$ \\
\hline \multicolumn{5}{|c|}{ I $P N A+\operatorname{surg} M E+A B$ vs $P N A+P h+A B$} \\
\hline Bos $2006(1)$ & $10 / 21$ & $12 / 25$ & + & $0.99[0.54,1.82]$ \\
\hline \multicolumn{5}{|c|}{2 Povidone-iodine with paraff gauze vs hydrogel with paraff gauze } \\
\hline Dovison 200। (2) & $1 / 13$ & $0 / 16$ & & $3.64[0.16,82.62]$ \\
\hline \multicolumn{5}{|c|}{3 Povidone-iodine with paraff gauze vs paraff gauze only } \\
\hline Dovison 200I (3) & $1 / 13$ & $1 / 13$ & & $1.00[0.07,14.34]$ \\
\hline \multicolumn{5}{|c|}{4 Hydrogel with paraff gauze vs paraff gauze only } \\
\hline Dovison 2001 (4) & $0 / 16$ & $1 / 13$ & & $0.27[0.01,6.23]$ \\
\hline \multicolumn{5}{|c|}{5 Manuka honey dressing vs paraff-impregn tulle gras } \\
\hline Mclntosh 2006 (5) & $0 / 52$ & $1 / 48$ & & $0.31[0.01,7.39]$ \\
\hline (5) $n=$ number of pat & & & & (Continued....) \\
\hline
\end{tabular}




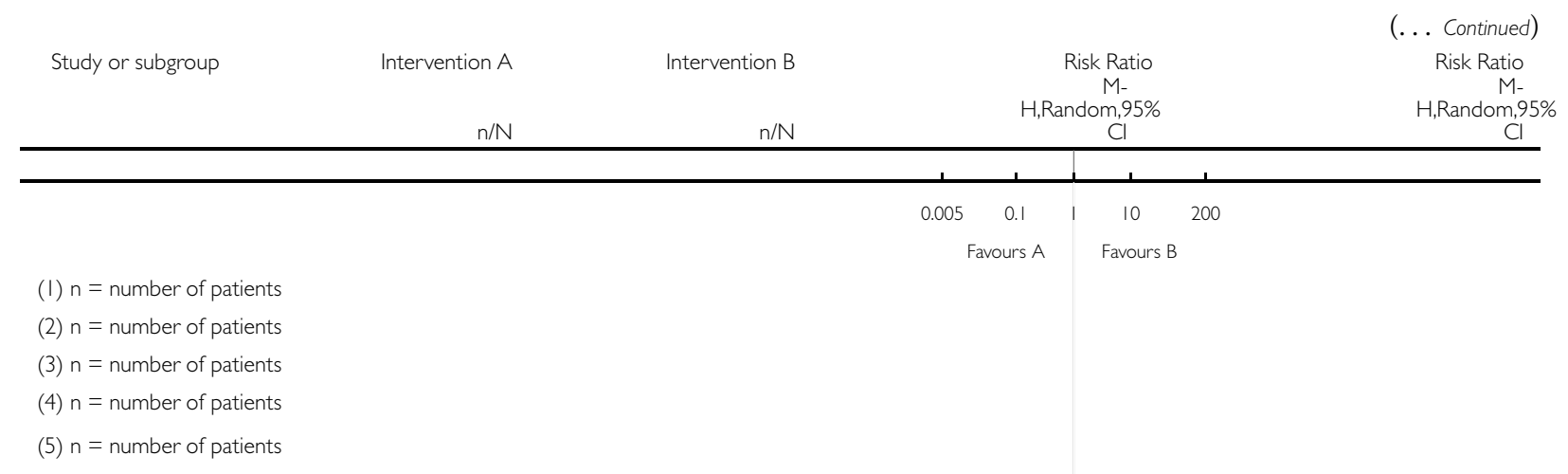

Analysis 7.3. Comparison 7 Postoperative procedures, Outcome 3 Postoperative pain (VAS).

Review: Interventions for ingrowing toenails

Comparison: 7 Postoperative procedures

Outcome: 3 Postoperative pain (VAS)

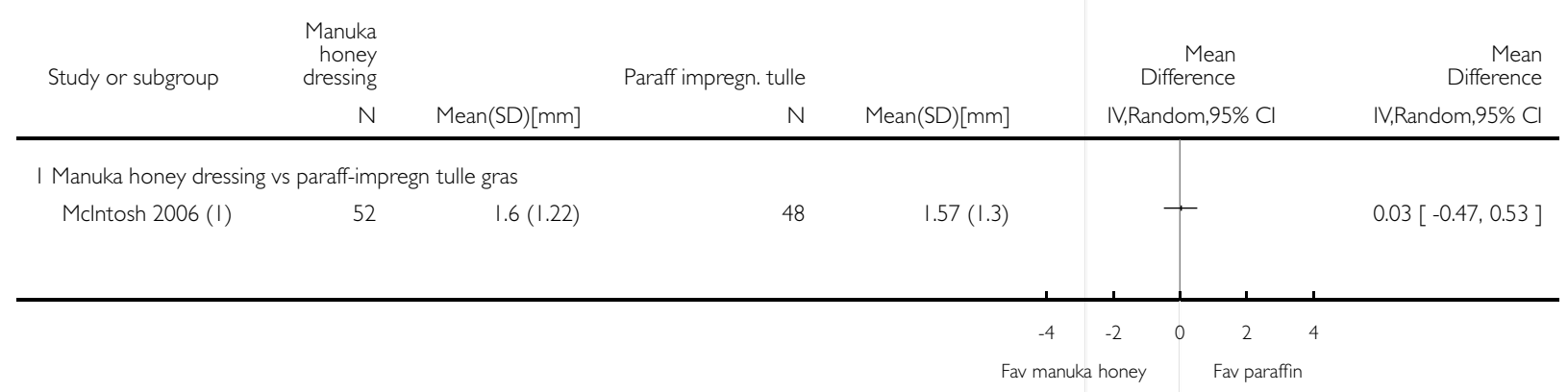

(I) $n=$ number of patients 
Analysis 7.4. Comparison 7 Postoperative procedures, Outcome 4 Healing time (days).

Review: Interventions for ingrowing toenails

Comparison: 7 Postoperative procedures

Outcome: 4 Healing time (days)

\begin{tabular}{|c|c|c|c|c|c|c|c|}
\hline \multirow[t]{2}{*}{ Study or subgroup } & \multirow{2}{*}{$\begin{array}{r}\text { Intervention A } \\
N\end{array}$} & \multicolumn{3}{|c|}{ Intervention B } & \multirow{2}{*}{\multicolumn{2}{|c|}{$\begin{array}{c}\text { Mean } \\
\text { Difference } \\
\text { IV,Random,95\% Cl }\end{array}$}} & \multirow{2}{*}{$\begin{array}{r}\text { Mean } \\
\text { Difference } \\
\text { IV,Random,95\% C }\end{array}$} \\
\hline & & $\operatorname{Mean}(\mathrm{SD})$ & N & Mean(SD) & & & \\
\hline \multicolumn{8}{|c|}{ I Povidone-iodine with paraff gauze vs hydrogel with paraff gauze } \\
\hline Dovison 2001 ( 1 ) & 13 & $34.3(4.8)$ & 13 & $34.2(7.7)$ & & + & $0.10[-4.83,5.03]$ \\
\hline \multicolumn{8}{|c|}{2 Povidone-iodine with paraff gauze vs paraff gauze only } \\
\hline Dovison 200। (2) & 13 & $34.3(4.8)$ & 16 & $33.3(6)$ & & 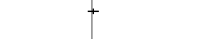 & $1.00[-2.93,4.93]$ \\
\hline \multicolumn{8}{|c|}{3 Hydrogel with paraff gauze vs paraff gauze only } \\
\hline Dovison 2001 (3) & 13 & $34.2(7.7)$ & 16 & $33.3(6)$ & & t & $0.90[-4.22,6.02]$ \\
\hline \multicolumn{8}{|c|}{4 Manuka honey dressing vs paraff-impregn tulle gras } \\
\hline \multirow[t]{3}{*}{ Mclntosh 2006 (4) } & 52 & $40.3(18.21)$ & 48 & $39.98(25.42)$ & & t & $0.32[-8.41,9.05]$ \\
\hline & & & & & -100 & -50 & 100 \\
\hline & & & & & & Favours $\mathrm{E}$ & \\
\hline
\end{tabular}

(I) $n=$ number of patients

(2) $n=$ number of patients

(3) $n=$ number of patients

(4) $n=$ number of patients

Analysis 8.I. Comparison 8 Surgery plus postoperative treatment vs surgery, Outcome I Recurrence.

Review: Interventions for ingrowing toenails

Comparison: 8 Surgery plus postoperative treatment vs surgery

Outcome: | Recurrence

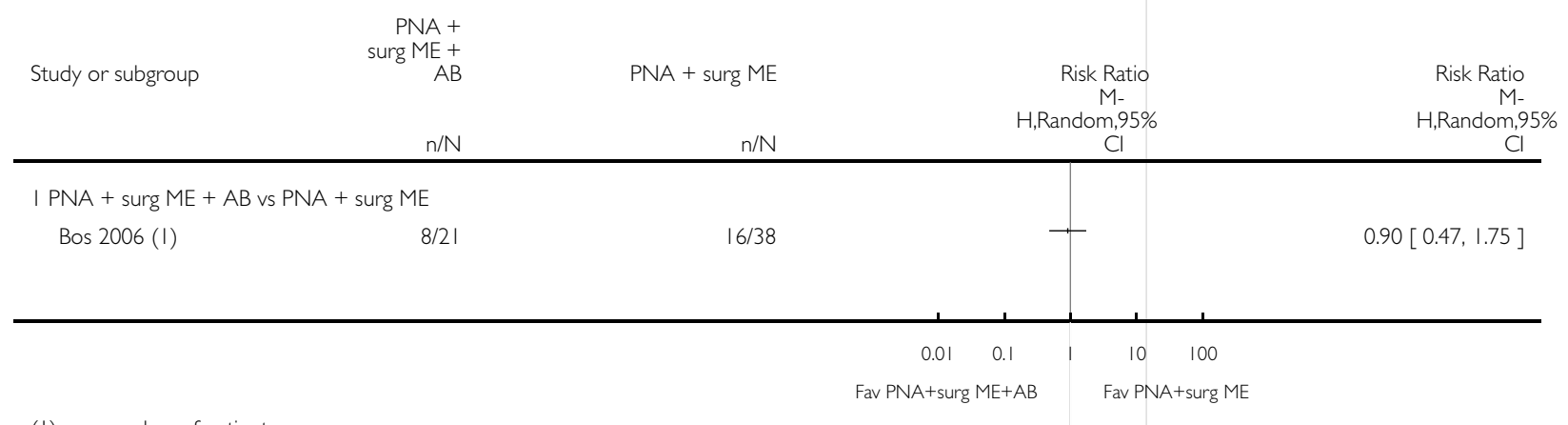

(I) $n=$ number of patients

Interventions for ingrowing toenails (Review)

Copyright (C) 2012 The Cochrane Collaboration. Published by John Wiley \& Sons, Ltd. 
Analysis 8.2. Comparison 8 Surgery plus postoperative treatment vs surgery, Outcome 2 Postoperative infection.

Review: Interventions for ingrowing toenails

Comparison: 8 Surgery plus postoperative treatment vs surgery

Outcome: 2 Postoperative infection

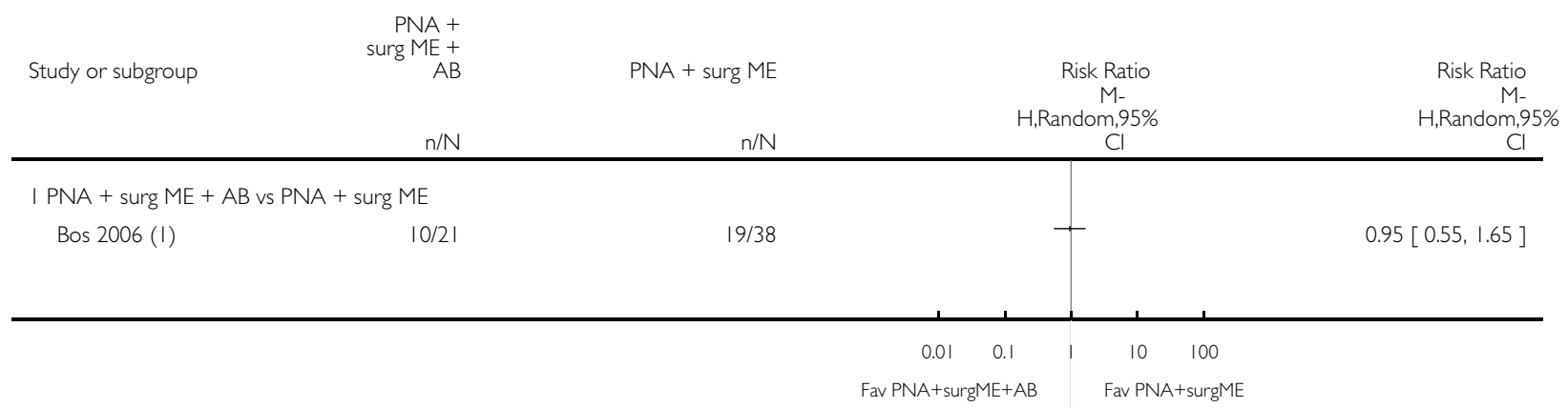

( $) \mathrm{n}=$ number of patients

Analysis 9.I. Comparison 9 Surgery plus postoperative treatment vs phenol, Outcome I Recurrence.

Review: Interventions for ingrowing toenails

Comparison: 9 Surgery plus postoperative treatment vs phenol

Outcome: | Recurrence

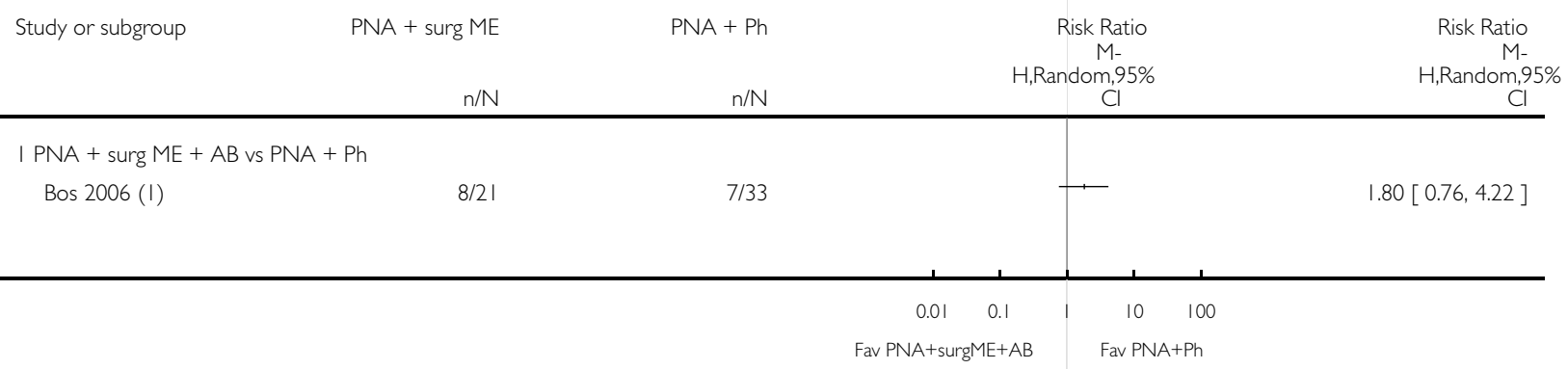

( 1 ) n = number of patients 
Analysis 9.2. Comparison 9 Surgery plus postoperative treatment vs phenol, Outcome 2 Postoperative infection.

Review: Interventions for ingrowing toenails

Comparison: 9 Surgery plus postoperative treatment vs phenol

Outcome: 2 Postoperative infection

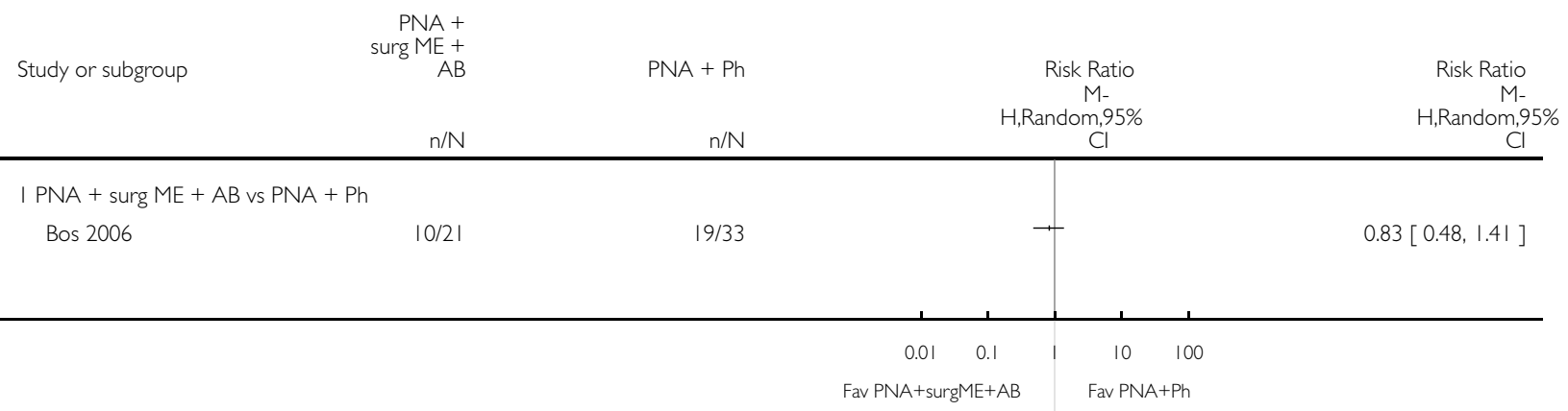

Analysis 10.I. Comparison IO Phenol plus postoperative treatment vs phenol, Outcome I Recurrence.

Review: Interventions for ingrowing toenails

Comparison: 10 Phenol plus postoperative treatment vs phenol

Outcome: I Recurrence

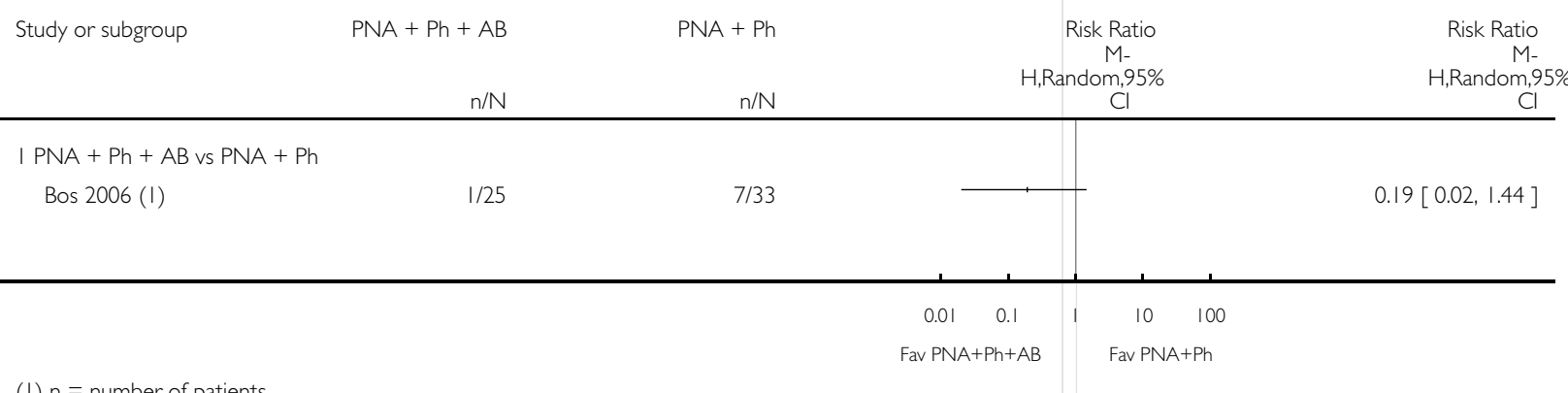

(I) $n$ = number of patients 
Analysis 10.2. Comparison 10 Phenol plus postoperative treatment vs phenol, Outcome 2 Postoperative infection.

Review: Interventions for ingrowing toenails

Comparison: 10 Phenol plus postoperative treatment vs phenol

Outcome: 2 Postoperative infection

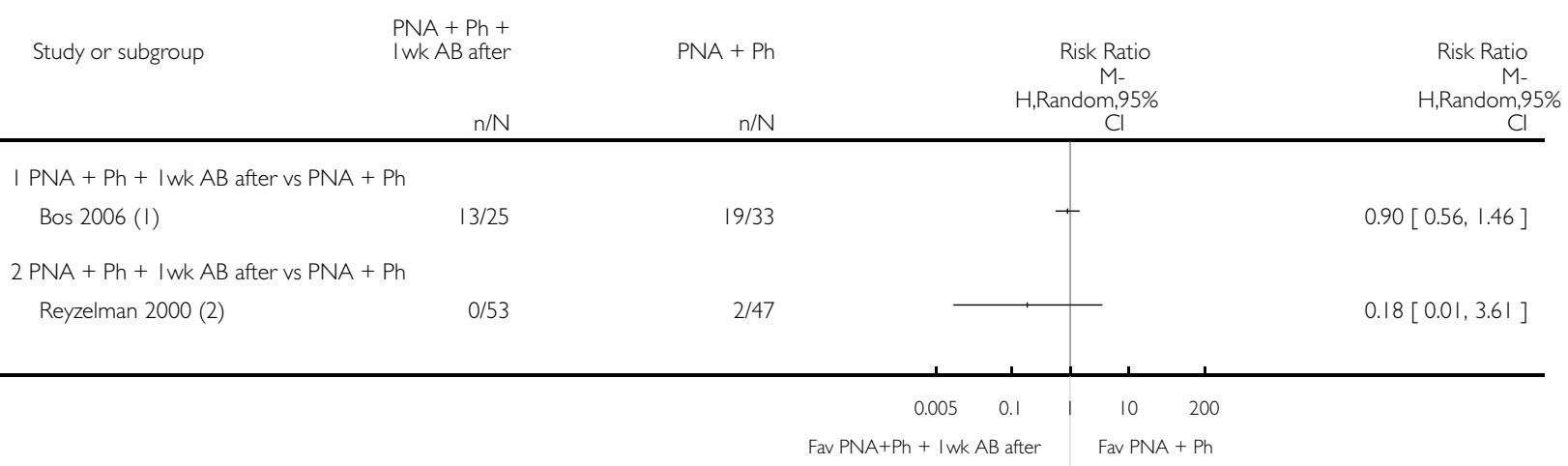

(I) $n=$ number of patients

(2) $n=$ number of patients

Analysis 10.3. Comparison 10 Phenol plus postoperative treatment vs phenol, Outcome 3 Healing time (weeks).

Review: Interventions for ingrowing toenails

Comparison: 10 Phenol plus postoperative treatment vs phenol

Outcome: 3 Healing time (weeks)

\begin{tabular}{|c|c|c|c|c|c|c|}
\hline \multirow[t]{2}{*}{ Study or subgroup } & $\begin{array}{l}\text { PNA + Ph } \\
+\mathrm{AB} \text { after }\end{array}$ & & $\mathrm{Ph}$ & & $\begin{array}{r}\text { Mean } \\
\text { Difference }\end{array}$ & $\begin{array}{r}\text { Mean } \\
\text { Difference }\end{array}$ \\
\hline & $\mathrm{N}$ & Mean(SD) & $N$ & Mean(SD) & IV,Random,95\% Cl & IV,Random,95\% Cl \\
\hline
\end{tabular}

I PNA + Ph + Iwk AB afterwards vs PNA + Ph

$\begin{array}{lllll}\text { Reyzelman } 2000(\mathrm{I}) & 53 & 1.9(0.7) & 47 & 2(0.8)\end{array}$

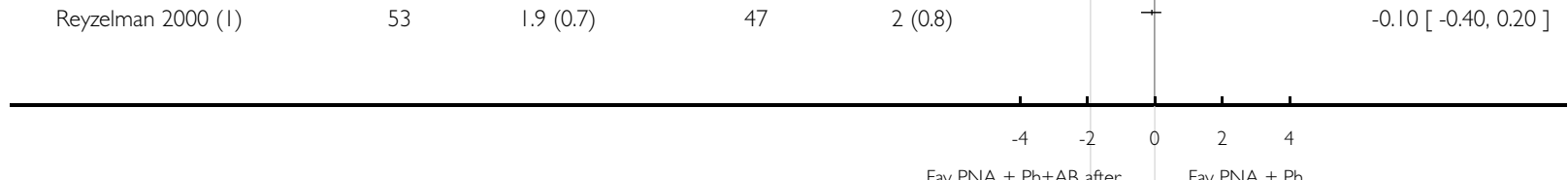

(I) $n$ = number of patients 
Analysis II.I. Comparison II Phenol plus postoperative treatment vs surgery, Outcome I Recurrence. Review: Interventions for ingrowing toenails

Comparison: II Phenol plus postoperative treatment vs surgery

Outcome: I Recurrence

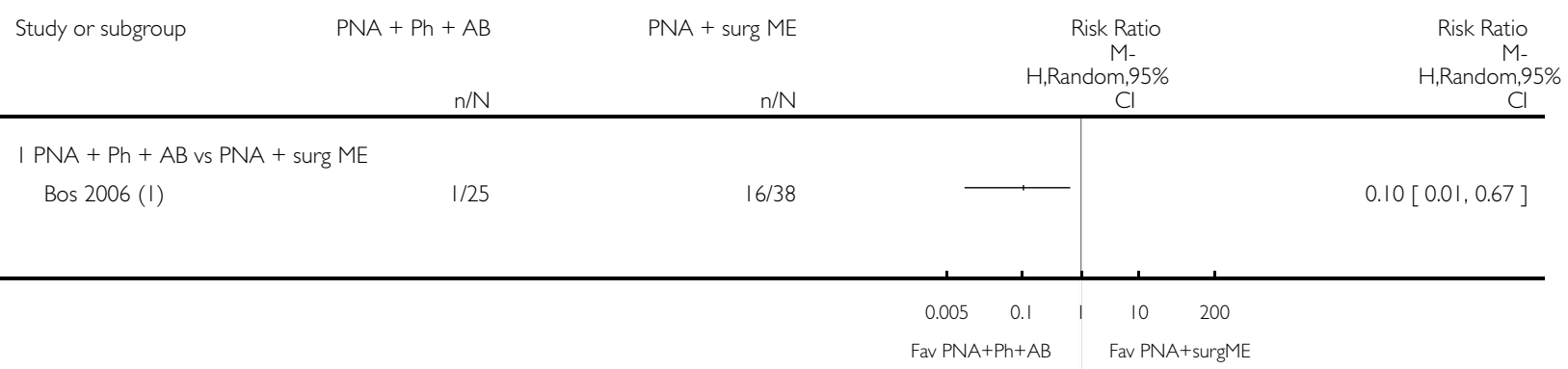

(I) $n$ = number of patients

Analysis II.2. Comparison II Phenol plus postoperative treatment vs surgery, Outcome 2 Postoperative infection.

Review: Interventions for ingrowing toenails

Comparison: II Phenol plus postoperative treatment vs surgery

Outcome: 2 Postoperative infection

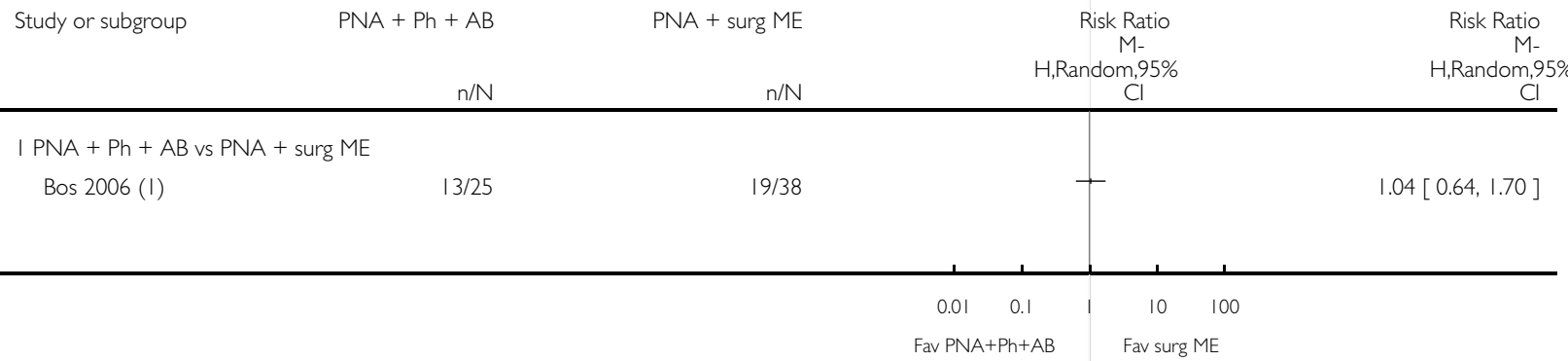

(I) $n$ = number of patients 
Analysis 12.1. Comparison I2 Preoperative treatment vs postoperative treatment, Outcome I Healing time (weeks).

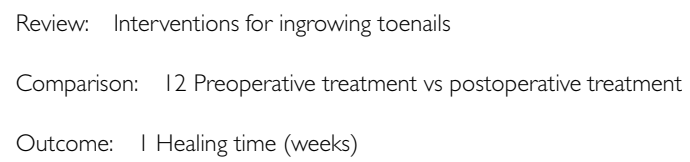

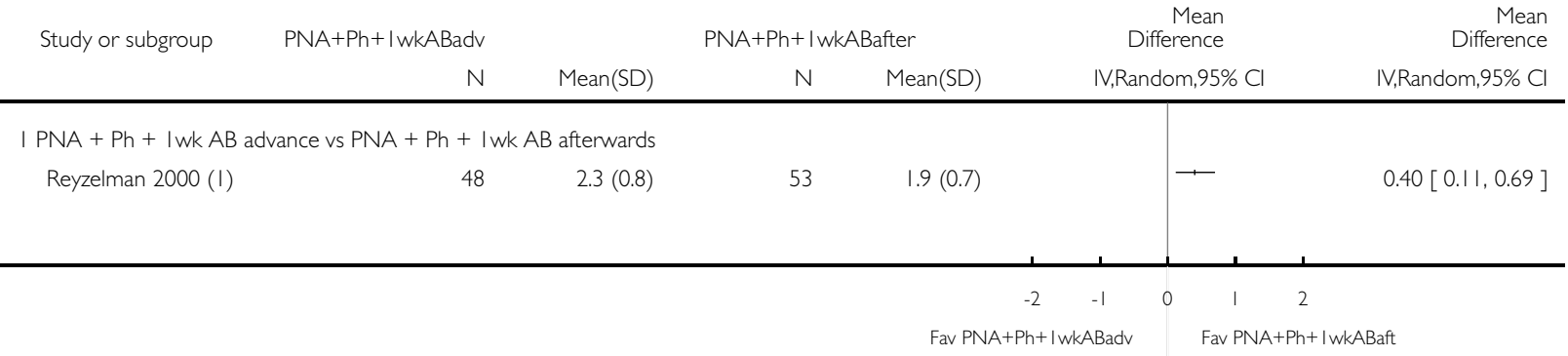

(I) $n$ = number of patients

\section{Analysis I3.I. Comparison I3 Preoperative treatment vs surgery, Outcome I Postoperative infection.}

Review: Interventions for ingrowing toenails

Comparison: 13 Preoperative treatment vs surgery

Outcome: I Postoperative infection

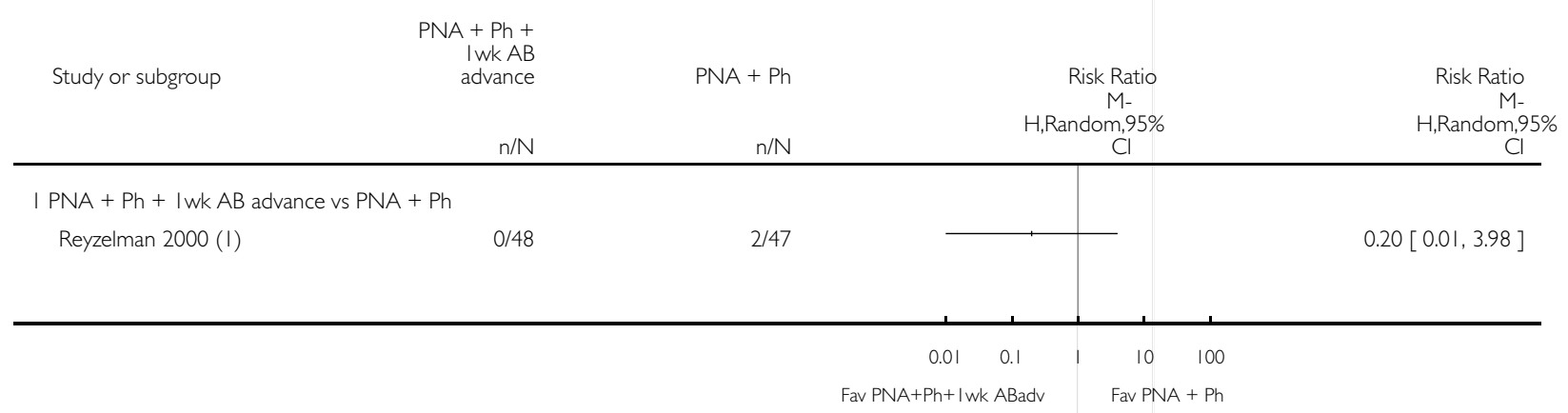

(I) $n=$ number of patients 
Analysis 13.2. Comparison 13 Preoperative treatment vs surgery, Outcome 2 Healing time (weeks).

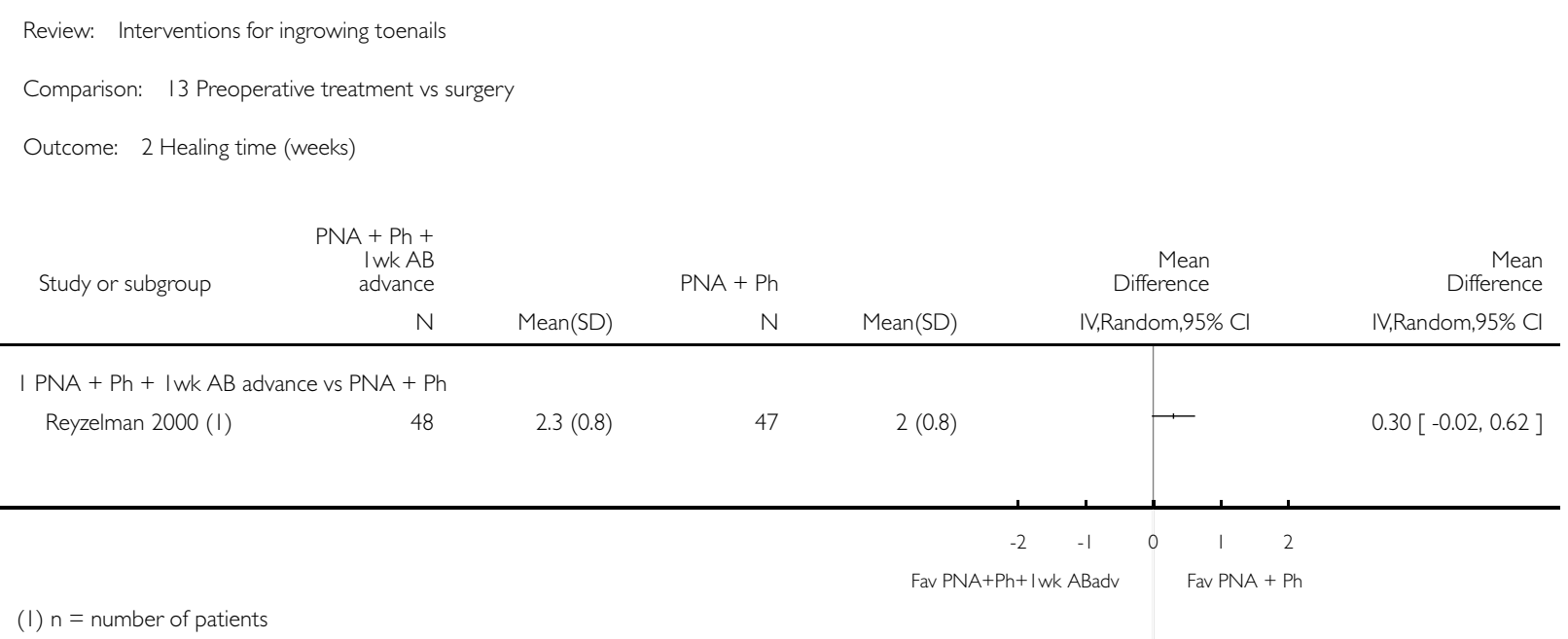

\section{A P PENDICES}

\section{Appendix I. CENTRAL (Cochrane Library) search strategy}

ingrowing toenail OR ingrown toenail OR ingrown nail OR unguis incarnatus OR onychocryptosis OR onychogryphosis OR involuted toenail OR embedded toenail OR eingewachsenen Zehnennagel OR ingrowing toenails OR ingrown toenails OR ingrown nails OR involuted toenails OR embedded toenails OR eingewachsenen Zehnennagels OR ingrowing nail OR involuted nail OR embedded nail OR eingewachsenen nagel OR ingrowing nails OR ingrown nails OR involuted nails OR embedded nails OR eingewachsenen nagels

\section{Appendix 2. MEDLINE search strategy}

(Nails, Ingrown/ OR (“ingrowing toenail” OR “ingrown toenail” OR “ingrown nail” OR "unguis incarnatus” OR onychocryptosis OR onychogryphosis OR "involuted toenail” OR “embedded toenail” OR “eingewachsenen Zehnennagel” OR “ingrowing toenails” OR "ingrown toenails" OR "ingrown nails" OR "involuted toenails" OR "embedded toenails" OR "eingewachsenen Zehnennagels" OR "ingrowing nail" OR "involuted nail” OR "embedded nail" OR "eingewachsenen nagel” OR "ingrowing nails" OR "ingrown nails" OR “involuted nails” OR “embedded nails” OR "eingewachsenen nagels”).af) AND (Randomized Controlled Trial/ OR (randomized controlled trial OR randomized controlled trials OR random allocation OR double-blind method OR single-blind method OR ((single OR double OR treble OR triple) AND (mask OR masks OR masking OR blind OR blinds OR blinded)) OR "latin square" OR placebos OR placebo* OR random* OR randomised controlled trial OR randomised controlled trials OR randomized active control trials OR randomized active control trial OR randomised active control trials OR randomised active control trial OR RaCT OR RaCTs OR RCT OR RCTs).af) 


\section{Appendix 3. EMBASE search strategy}

(Ingrown Nail/ OR (“ingrowing toenail” OR “ingrown toenail” OR “ingrown nail” OR “unguis incarnatus” OR onychocryptosis OR onychogryphosis OR “involuted toenail” OR “embedded toenail” OR “eingewachsenen Zehnennagel” OR “ingrowing toenails” OR "ingrown toenails" OR "ingrown nails" OR "involuted toenails" OR "embedded toenails" OR "eingewachsenen Zehnennagels" OR "ingrowing nail" OR "involuted nail" OR "embedded nail" OR "eingewachsenen nagel" OR "ingrowing nails" OR "ingrown nails" OR "involuted nails" OR "embedded nails" OR "eingewachsenen nagels").mp) AND (Randomized Controlled Trial/ OR (randomized controlled trial OR randomized controlled trials OR random allocation OR double-blind method OR single-blind method OR ((single OR double OR treble OR triple) AND (mask OR masks OR masking OR blind OR blinds OR blinded)) OR "latin square" OR placebos OR placebo* OR random* OR randomised controlled trial OR randomised controlled trials OR randomized active control trials OR randomized active control trial OR randomised active control trials OR randomised active control trial OR RaCT OR RaCTs OR RCT OR RCTs).af)

\section{Appendix 4. CINAHL search strategy}

Nails, Ingrown/ OR (“ingrowing toenail” OR “ingrown toenail” OR “ingrown nail" OR "unguis incarnatus" OR onychocryptosis OR onychogryphosis OR "involuted toenail” OR “embedded toenail” OR “eingewachsenen Zehnennagel” OR "ingrowing toenails" OR “ingrown toenails" OR “ingrown nails" OR "involuted toenails" OR "embedded toenails" OR "eingewachsenen Zehnennagels" OR "ingrowing nail" OR "involuted nail" OR "embedded nail” OR "eingewachsenen nagel” OR "ingrowing nails" OR "ingrown nails” OR “involuted nails” OR “embedded nails” OR “eingewachsenen nagels” OR “ingrown toe nail” OR "ingrowing toe nail” OR "ingrown toe nails" OR “ingrowing toe nails" OR "nail ingrowing”).mp

\section{Appendix 5. Web of Science search strategy}

ts=(“ingrowing toenail” OR “ingrown toenail” OR “ingrown nail” OR “unguis incarnatus" OR onychocryptosis OR onychogryphosis OR “involuted toenail” OR "embedded toenail" OR “eingewachsenen Zehnennagel” OR “ingrowing toenails" OR “ingrown toenails" OR “ingrown nails" OR “involuted toenails" OR “embedded toenails” OR “eingewachsenen Zehnennagels" OR "ingrowing nail” OR "involuted nail" OR "embedded nail" OR "eingewachsenen nagel” OR “ingrowing nails" OR "ingrown nails" OR "involuted nails" OR "embedded nails" OR "eingewachsenen nagels" OR "ingrown toe nail" OR “ingrowing toe nail" OR "ingrown toe nails" OR "ingrowing toe nails" OR "nail ingrowing”)

\section{WHAT'S NEW}

Last assessed as up-to-date: 20 January 2010.

\begin{tabular}{l|l|l}
\hline Date & Event & Description \\
\hline 15 February 2012 & New search has been performed & $\begin{array}{l}\text { New search for studies. A substantial amount of new } \\
\text { information has been added in the form of } 17 \text { newly } \\
\text { included studies }\end{array}$ \\
\hline 15 February 2012 & New citation required and conclusions have changed & $\begin{array}{l}\text { The title and scope of this review has been expanded } \\
\text { with a new team of authors }\end{array}$ \\
\hline
\end{tabular}




\section{H I S T O R Y}

Protocol first published: Issue 2, 1999

Review first published: Issue 3, 1999

\section{CONTRIBUTIONS OFAUTHORS}

Link with the editorial base and co-ordinating contributions from co-authors - JAHE

Searches - JAHE, JCvdW, and JS

Screening the abstracts - AKN and JAHE

Obtaining copies of the trials - JAHE and JCvdW

Assessing the full papers for inclusion - JAHE and BvW

Extracting data from the trials - JCvdW and BvW

Assessing the methodological quality - JAHE, JCvdW, and BvW

Entering the data into RevMan - JCvdW and BvW

Writing the text of the review - AKN, JAHE, JCvdW, and BvW

Consumer feedback on the synopsis - BvW

\section{DECLARATIONS OF INTEREST}

None known.

\section{SOURCES OFSUPPORT}

\section{Internal sources}

- Department of Public Health and Primary Care, Leiden University Medical Center, Leiden, Netherlands.

- Department of General Practice, Erasmus MC, Rotterdam, Netherlands.

\section{External sources}

- No sources of support supplied 


\section{DIFFERENCES BETWEEN PROTOCOLAND REVIEW}

The Background, Objectives, Criteria, Search, and Methods sections of the protocol and first version of this review published in 1999 and 2003, respectively, were compared, and they remain the same.

This review is an update of the review by Rounding and Bloomfield titled 'Surgical treatments for ingrowing toenails' (Rounding 2003). The title has been changed to 'Interventions for ingrowing toenails' because this updated review has focused on all interventions (surgical as well as non-surgical) for ingrowing toenails. We, therefore, amended the search strategies to incorporate this change.

Other changes are as follows:

- We excluded quasi-randomised studies (e.g. allocation by an odd or even number or date of birth) from this update.

- We added recurrence as a primary outcome.

- In the selection of studies, we divided studies into those we defined as follow-up period for cure (one month or more) and recurrence (six months or more), and into secondary outcome measures (clinical judgment, participant satisfaction, complications, improvement of symptoms).

- We used the risk ratio (RR) effects measure in this update, rather than the odds ratio (OR) that was used in the previous version of this review. This is because risk and odds are different when events are common, and many of the outcomes of trials of skin conditions are common events. This is in line with the Cochrane Skin Group's editorial policy.

\section{N DEX TERMS}

\section{Medical Subject Headings (MeSH)}

Combined Modality Therapy; Nails, Ingrown [prevention \& control; *surgery]; Phenol [therapeutic use]; Randomized Controlled Trials as Topic; Recurrence [prevention \& control]; Toes

\section{MeSH check words}

Humans 